LA--12376-MS

DE93 006097

A Summary and Discussion of Hydrologic Data from the Calico Hills Nonwelded Hydrogeologic Unit at Yucca Mountain, Nevada

Colleen Loeven 
TABLE OF CONTENTS

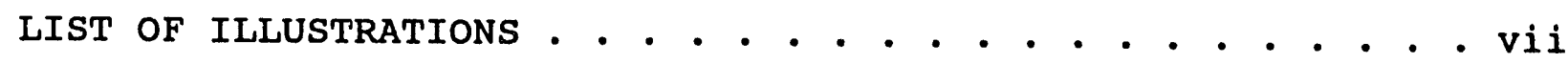

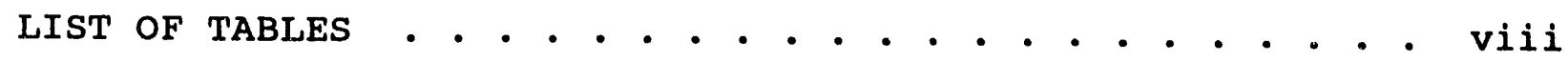
ABSTRACT . . . . . . . . . . . . . . . . . . . . . 1

I. INTRODUCTION • . . . . . . . . . . . . . . . . . . 2

II. STRATIGRAPHY • . . . . . . . . . . . . . . • . . . 3

III. HYDROLOGIC PROPERTIES . . . . . . . . . . . . . . . . . 11

3.1. Saturated Hydraulic Conductivity . . . . . . . . 15

3.1.a. Laboratory Measurements . . . . . . . 16

3.1.b. Aquifer Tests . . . . . . . . . . 26

3.1.C. Discussion . . . . . . . . . . . 29

3.2. Unsaturated Hydraulic Conductivity . . . . . . . 29

3.3. Fluid potentials and Saturations . . . . . . . . 34

3.4. Total and Kinematic Porosity . . . . . . . . . 35

3.5. Pore-Size Distribution . . . . . . . . . . . 37

3.6. Dispersion . . . . . . . . . . . . . . . 39

3.7. Storage Coefficients . . . . . . . . . . . 40

3.7.a. Specific Storage ........... . . 40

3.7.b. Capacitance . . . . . . . . . . . 41

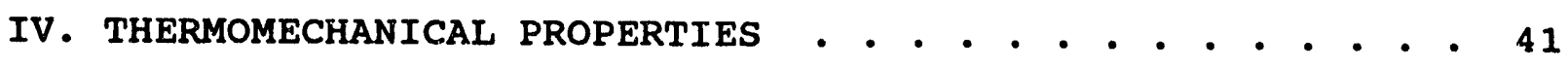

V. CONCLUSIONS AND RECOMMENDATIONS . • • • • • • • • . . . . . 42

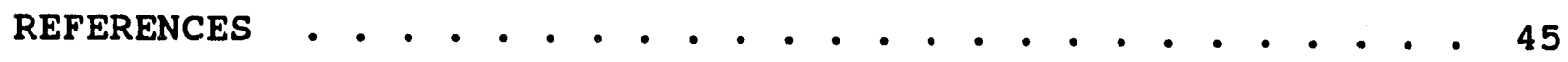

APPENDIX A RELATIVE ABUNDANCE OF MINERALS AND GLASS IN

SELECTED WELLS AT YUCCA MOUNTAIN, NEVADA AFTER BISH AND

CHIPERA, 1989 . . . . . . . . . . . . . . . . . . . 


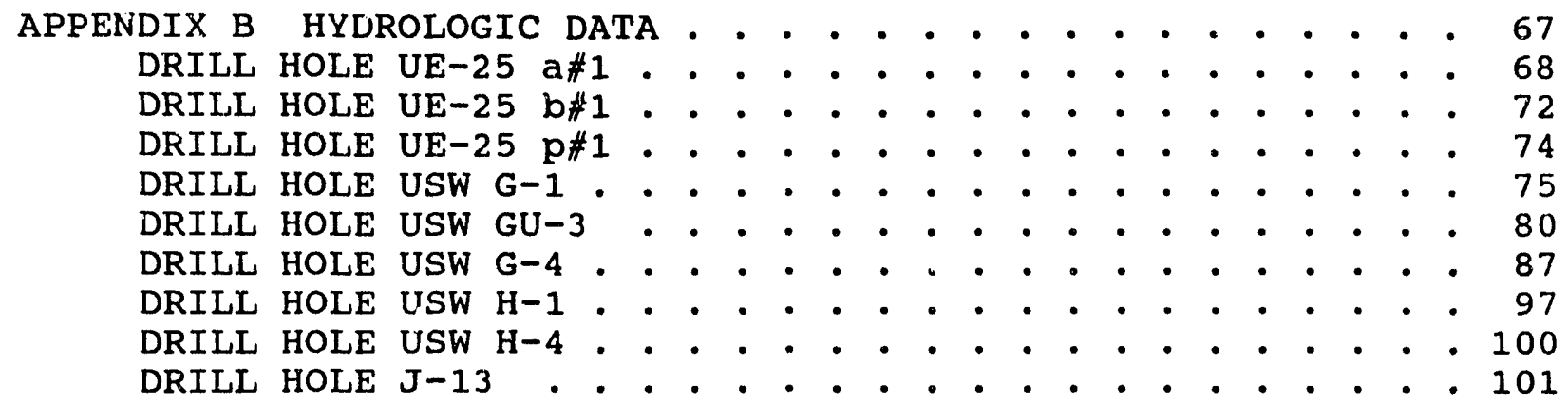




\section{LIST OF ILLUSTRATIONS}

Figure

Page

1. Index map showing the locations of selected drill holes in the vicinity of Yucca Mountain and the locations of cross-sections shown in Figures $2 a$ and $2 b$. After U.S.

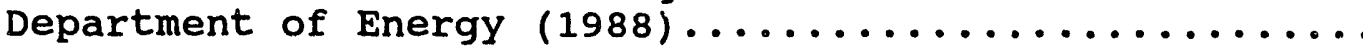

2a. North-south stratigraphic correlation between selected drill holes at Yucca Mountain. Vertical:horizontal scale $=2.5: 1$. After U.S.

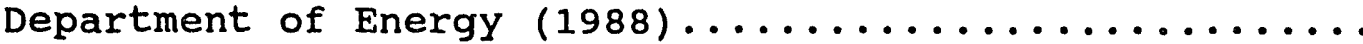

2b. East-west stratigraphic correlation between selected drill holes at Yucca Mountain. Vertical:horizontal scale $=2.5: 1$. After U.S. Department of Energy (1988).

3a. Sorptive stratigraphy of Yucca Mountain (Bryant and Vaniman, 1984). After Tien et al. (1985)............

3b. Sorptive stratigraphy of Yucca Mountain (Bryant and Vaniman, 1984). After Tien et al. (1985)...........

4. Log-normal probability plot of devitrified, vitric and zeolitic laboratory hydraulic conductivity data.......

5. Log-normal probability plot of all laboratory hydraulic

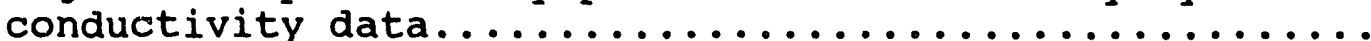

6. Log-normal probability plot of aquifer test hydraulic

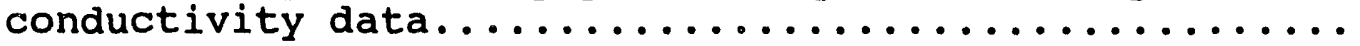


1. Thickness in meters of stratigraphic units included in this report in selected drill holes, in vertical sequence downward. Drill holes are selected for proximity to proposed repository. A hyphen (-) indicates unavailable data...................

2. Water table location, total Calico Hills nonwelded unit thickness and thickness of unsaturated Calico

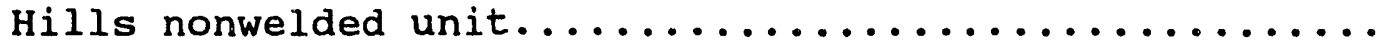

3. Definition of unsaturated-zone hydrogeologic units and correlation with rock-stratigraphic units. After U.S. Department of Energy $(1988) \ldots \ldots \ldots \ldots \ldots \ldots \ldots \ldots$

4. Number of measurements on different samples or subsamples by drill hole.......................

5. Number of samples, dimensions and source of laboratory hydraulic conductivity data from selected drill holes near Yucca Mountain, Nevada....................

6. Sample statistics of laboratory hydraulic conductivity data for vitric, devitrified and zeolitic tuffs and for

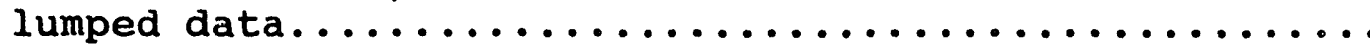

7. Base-ten logarithm of laboratory hydraulic conductivity (K) measurements for zeolitic tuffs and range, by drill hole. Originally in meters per second. (v)=vertical;

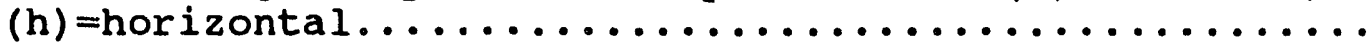

8. Sample statistics for aquifer test hydraulic conductivity data........................

9. Maximum and minimum hydraulic conductivity values and range of base-ten logarithms of aquifer test hydraulic

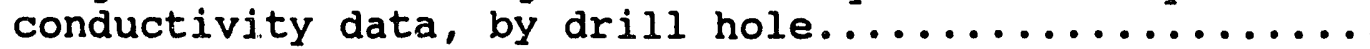

10. Data from laboratory and aquifer testing within selected overlapping intervals.......................

11. Sample statistics of saturation data for vitric, devitrified and zeolitic tuffs in the unsaturated zone.

12. Sample statistics of total porosity data for vitric, devitrified and zeolitic tuffs..................

13. Property values used to calculate specific storage..... 


\title{
A Summary and Discussion of Hydrologic Data from the Calico Hills Nonwelded Hydrogeologic Unit at Yucca Mountain, Nevada
}

by

Colleen Loeven

\begin{abstract}
This report is a summary of available hydrologic data from in situ and laboratory testing of the Calico Hills nonwelded hydrogeologic unit, including hydraulic conductivity, porosity, saturation, pore-size distribution and parameters from curve-fits to pressure-saturation data. Sample statistics of hydraulic conductivity, porosity and saturation data for vitric, devitrified and zeolitic tuffs are presented and discussed. While a high degree of variability is observed in both laboratory and in situ hydraulic conductivity measurements, uncertainties arising from differences in size of laboratory test samples, sample handling, test procedures and insufficient number of samples point to the need for additional data of specific types to adequately characterize the unit. Hydrologic issues related to transport analysis in the Calico Hills nonwelded hydrogeologic unit at Yucca Mountain are discussed together with recommendations for future work. The compiled data are included as an appendix.
\end{abstract}




\section{INTRODUCTION}

Performance assessment of a high-level radioactive waste repository site will depend in large part on numerical models of water and solute movement. Achieving projections of site containment of radionuclides requires an ability to conceptualize the hydrologic system and estimate the parameters that appear in the models. Unfortunately, our ability to develop sophisticated models exceeds our ability to estimate the parameters in the models. As pointed out by Luckner et al. (1989), this is especially true for the unsaturated hydraulic properties, which are by far the most important parameters affecting the rate at which water and dissolved chemicals move through unsaturated media.

The purpose of this report is to summarize currently available data from the Calico Hills nonwelded unit at yucca Mountain, Nevada, and to discuss the implications of available data on the direction of future work. Hydrologic data for the Calico Hills nonwelded unit are available in many puslications, always as part of a larger data set including stratigraphic units outside the unit of interest in this report. The data are presented in many different measurement units, making comparison difficult, and a number of different systems have been used for categorizing the stratigraphic members listed below. Subsets of the total data set have been used to estimate parameters for input to hydrologic models, but no systematic evaluation of the complete set has been made. This report provides a summary of relevant hydrologic data in a single document for use as a reference in planning and expediting future work in the Calico Hills unit, including evaluation of potential sites for field testing of numerical models and laboratory-derived transport parameters. Graphical summaries of relative abundance of minerals and glass by Bish and Chipera (1989) are included as Appendix A. A listing of the hydrologic data constitutes Appendix B.

Definition of the calico Hills nonwelded hydrogeologic unit is adopted from Montazer and Wilson (1984). The hydrogeologic unit consists of nonwelded and partially welded ash-flow and bedded tuffs located below the basal vitrophyre of the Topopah Spring Member of the Paintbrush Tuff and above the moderately welded interior of the Bullfrog Member of the crater Flat Tuff. Members of the hydrogeologic unit include the Lower Topopah Spring Member, the Tuffaceous Beds of the Calico Hills, the Prow Pass Member of the Crater Flat Tuff, the Upper Bullfrog Member and the bedded tuffs between them. It should be noted that in spite of its designation as a nonwelded unit, large sections of this hydrogeologic unit are described in lithologic logs as partially welded. Because the unit directly underlies the proposed repository, hydrologic and transport properties of the 
Calico Hills nonwelded unit are of primary importance to radionuclide containment assessment.

The Calico Hills unit is an important natural barrier to radionuclide migration from the proposed repository. Its properties include:

1. Hydrologic barrier - the response of nonwelded materials to stress is fundamentally different from that in brittle welded rocks. Failure is distributed over wider zones and faults and fractures are less likely to be discrete and continuous. Healing of fractures in nonwelded tuffs occurs under certain conditions. Nonwelded tuffs are known to contain fewer fractures than the brittle welded zones above and below the Calico Hills nonwelded unit. Also, flow in low permeability unsaturated media under small hydraulic gradients is slow.

2. Chemical barrier - as documented in mineralogic summaries (Broxton et al., 1989; Bish and Chipera, 1989; Bish et al., 1984), parts of the unit contain zeolites which are sorptive of certain radionuclides.

3. Physical barrier - the total present-day unsaturated thickness of the nonwelded and partially welded units is between $65.2 \mathrm{~m}$ (UE-25 b\#1) and $244.1 \mathrm{~m}$ (USW GU-3) in drill holes in the immediate vicinity of the proposed repository.

Figure 1 shows Yucca Mountain with drill hole locations and the proposed perimeter drift location.

Characteristics of flow and transport in the Calico Hills nonwelded unit have a major impact on estimated ground water travel times and radionuclide transport between the proposed repository and the accessible environment. A comprehensive hydrogeologic study of the nonwelded and partially welded tuffs underlying the proposed repository horizon in the unsaturated zone at Yucca Mountain is planned as part of site characterization.

\section{STRATIGRAPHY}

The Calico Hills nonwelded unit as defined here includes the following stratigraphic members, listed in vertical sequence downward. Table 1 lists thicknesses of members in selected drill holes as determined from stratigraphic logs. Location of drill holes in northern and southern parts of the exploration block is noted because of the change in degree of zeolitization of the unit from complete in the north to partial in the south. 


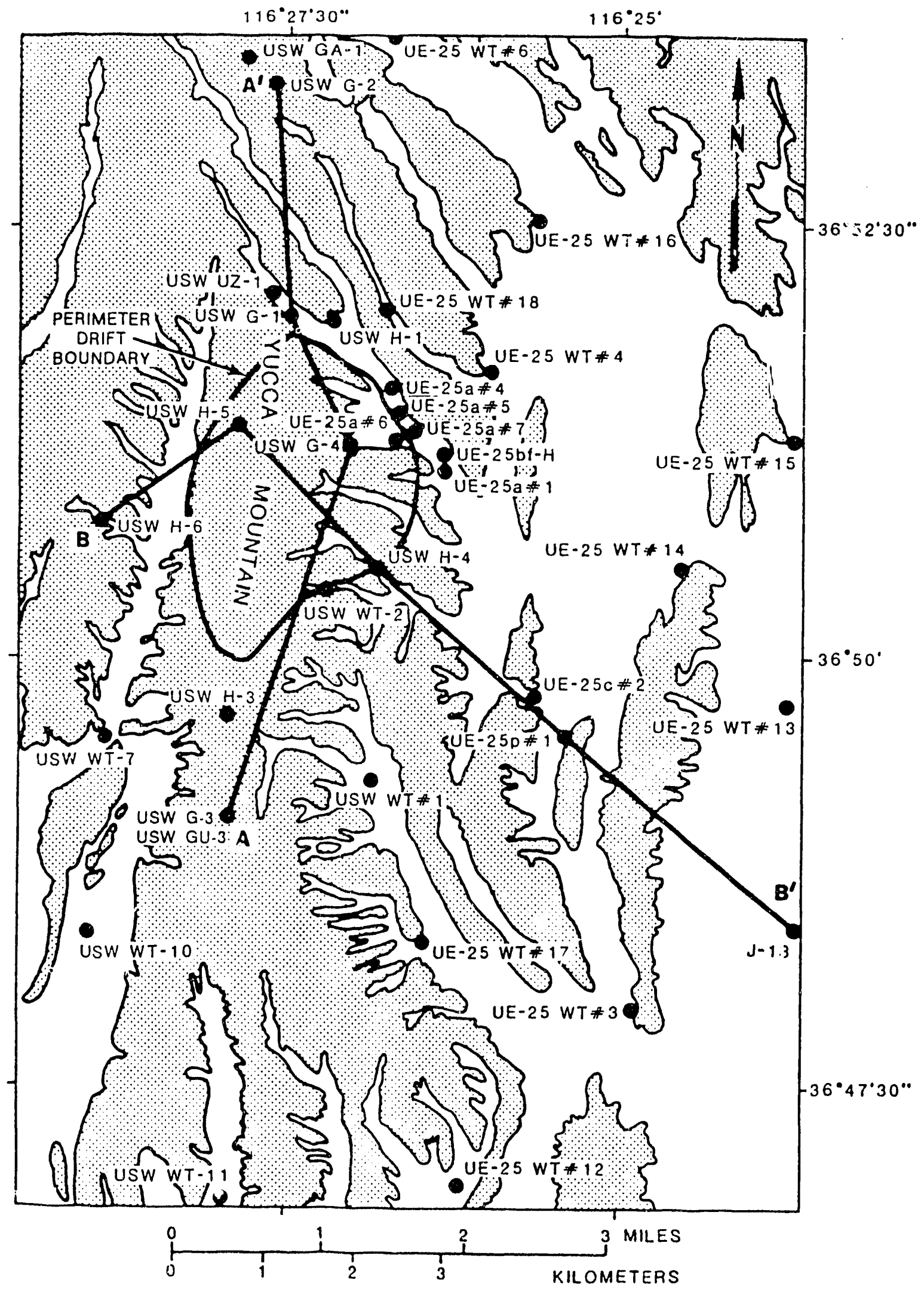

Figure 1. Index map showing the locations of selected drill holes in the vicinity of Yucca Mountain and the locations of cross-sections shown in Figures $2 \mathrm{a}$ and $2 \mathrm{~b}$. After U.S. Department o: Energy (1988). 
Table 1. Thickness in meters of stratigraphic units included in this report in selected drill holes, in vertical sequence downward. Drill holes are selected for proximity to proposed repository. A hyphen (-) indicates unavailable data.

$\begin{array}{ccc}\text { Lower } & & \text { Upper Strati- } \\ \text { Drill Topopah Bedded Calico Bedded Prow Bedded Bull- graphy }\end{array}$ Hole Spring Tuff Hills Tuff Pass Tuff frog Source

Northern Half of Proposed Repository Block

$\begin{array}{rrrrrrrrr}\text { UE-25 a\#1 } & 13.0 & 1.2 & 129.6 & 14.2 & 151.6 & 0.0 & 51.0 \pm & 1 \\ \text { UE-25 b\#1 } & 6.1 & 10.7 & 138.7 & 8.8 & 148.3 & 1.7 & 67.7 & 2 \\ \text { USW G-1 } & 13.2 & 6.6 & 94.8 & 19.8 & 106.8 & 6.4 & 83.5 & 3 \\ \text { USW G-4 } & 16.2 & 0.8 & 90.2 & 17.0 & 145.1 & 2.0 & 38.4 & 4 \\ \text { USW H- } & - & 5.0 & 90.0 & 17.0 & 135.0 & 7.0 & 113.0 & 5 \\ \text { USW H-5 } & 13.5 & 3.4 & 51.8 & 19.8 & 89.9 & 7.0 & 105.7 & 6\end{array}$

Southern Half of Proposed Repository Block

$\begin{array}{lcccccccc}\text { USW GU-3 } & 32.7 & 2.0 & 28.6 & 16.3 & 131.5 & 4.0 & 29.0 & 7 \\ \text { USW H-3 } & 42.7 & 0.0 & 28.9 & 0.0 & 125.9 & 2.2 & 28.3 & 8 \\ \text { USW H-4 } & 29.0 & 0.0 & 80.2 & 15.8 & 193.9 & 3.6 & 68.6 & 9 \\ \text { USW WT-2 } & - & - & 89.0 & - & 142.0+ & - & - & 10\end{array}$

a Detailed stratigraphic logs unavailable.

Sources:

1. Spengler et al., 1979.

2. Lobmeyer et al., 1983.

3. Spengler et al., 1981 .

4. Spengler and Chornack, 1984.

5. Rush et al., 1983.

6. Bentley et al., 1983 .

7. Scott and Castellanos, 1984.

8. Thordarson et al., 1984.

9. Whitfield et al., 1984 .

10. Muller and Kibler, 1985. 
Vitric tuffs are formed when ash-flow deposits cool before crystallization can occur. Devitrified tuffs result from hightemperature crystallization during cooling of an ash-flow sheet, while zeolitic tuffs are the result of low-temperature replacement of glass during secondary alteration. clinoptilolite is the predominant zeolite at Yucca Mountain, accompanied by varying amounts of mordenite and analcime.

Stratigraphic members of the Calico Hills hydrogeologic unit include the following:

1. Lower part of Topopah spring Member - partially welded grading downward to nonwelded vitric to zeolitic tuffs below the basal vitrophyre.

2. Bedded ash-fall and reworked tuffs - between the Topopah Spring Member and the Tuffaceous Beds of the Calico Hills.

3. Tuffaceous Beds of the Calico Hills - informal stratigraphic unit consisting of a series of up to 16 relatively massive, homogeneous nonwelded ash-flow tuff units separated by thin (up to $4-\mathrm{m}$ thick) bedded to massive air fall tuffs (Spengler et al., 1979; 1981), zeolitized in the north of the exploration block, vitric to the south.

4. Bedded ash-fall and reworked tuffs - separating the Tuffaceous Beds of the Calico Hills from the Prow Pass Member.

5. Prow Pass Member - nonwelded to partially welded ashflow tuff, vitric to zeolitic in upper part, devitrified in central part and zeolitic in lower part (interior moderately welded in places).

6. Bedded ash-fall and reworked tuffs - separating the Prow Pass Member from the Bullfrog Member.

7. Upper part of Bullfrog Member - nonwelded to partially welded vitric, devitrified and zeolitic tuffs.

Stratigraphy at Yucca Mountain is shown in Figures $2 a$ and $2 \mathrm{~b}$; location of the cross-sections is indicated on Figure 1 . The unit dips gently to the east and is crossed by the Ghost Dance fault. Table 2 irdicates water table location in each of the drill holes list $\Leftrightarrow d$ in Table 1 and the total thickness and total unsaturated thickness of the hydrologic unit in those drill holes.

Table 3 illustrates the correlation between Montazer and wilson's hydrogeologic units and rock-stratigraphic units. 


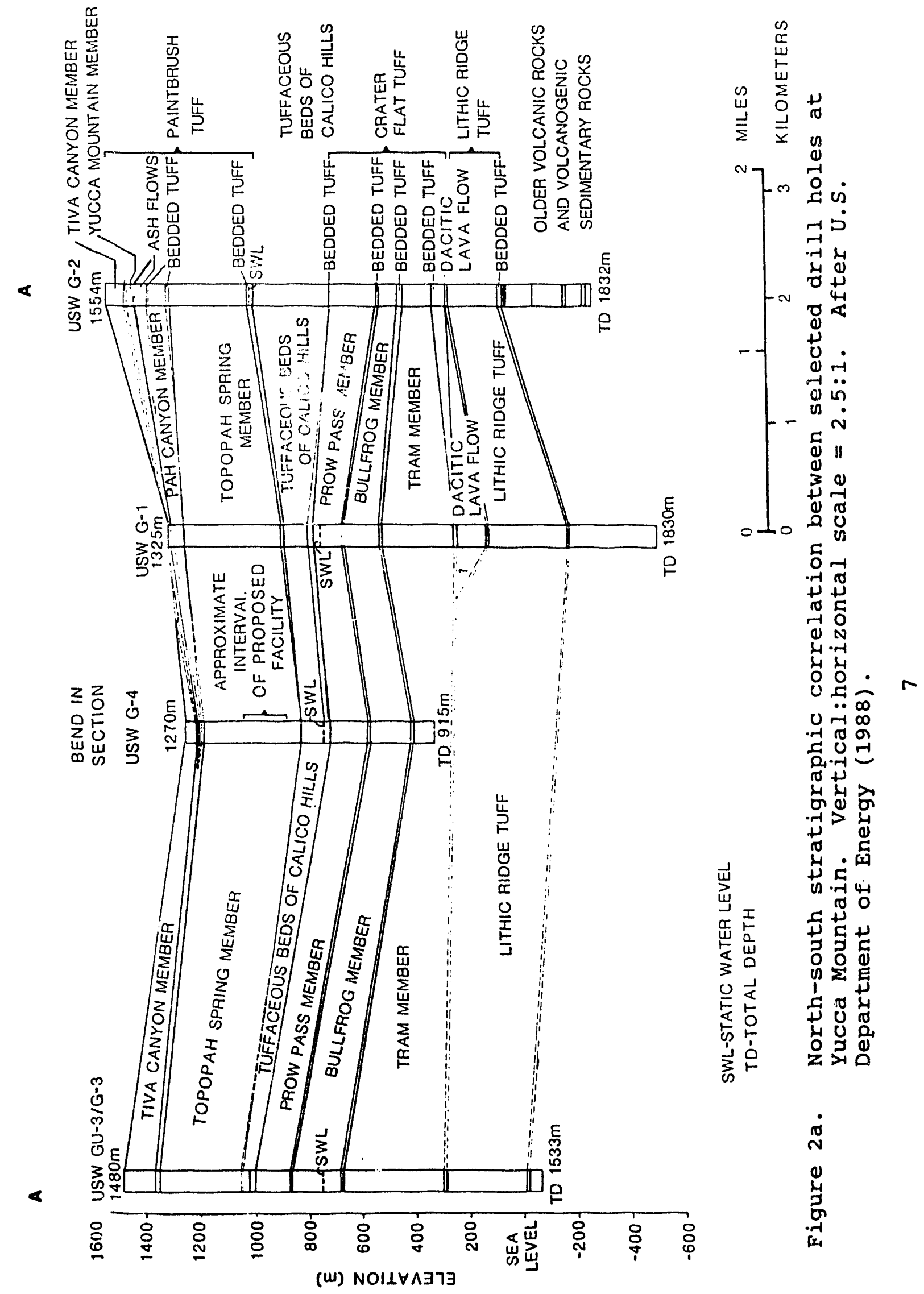




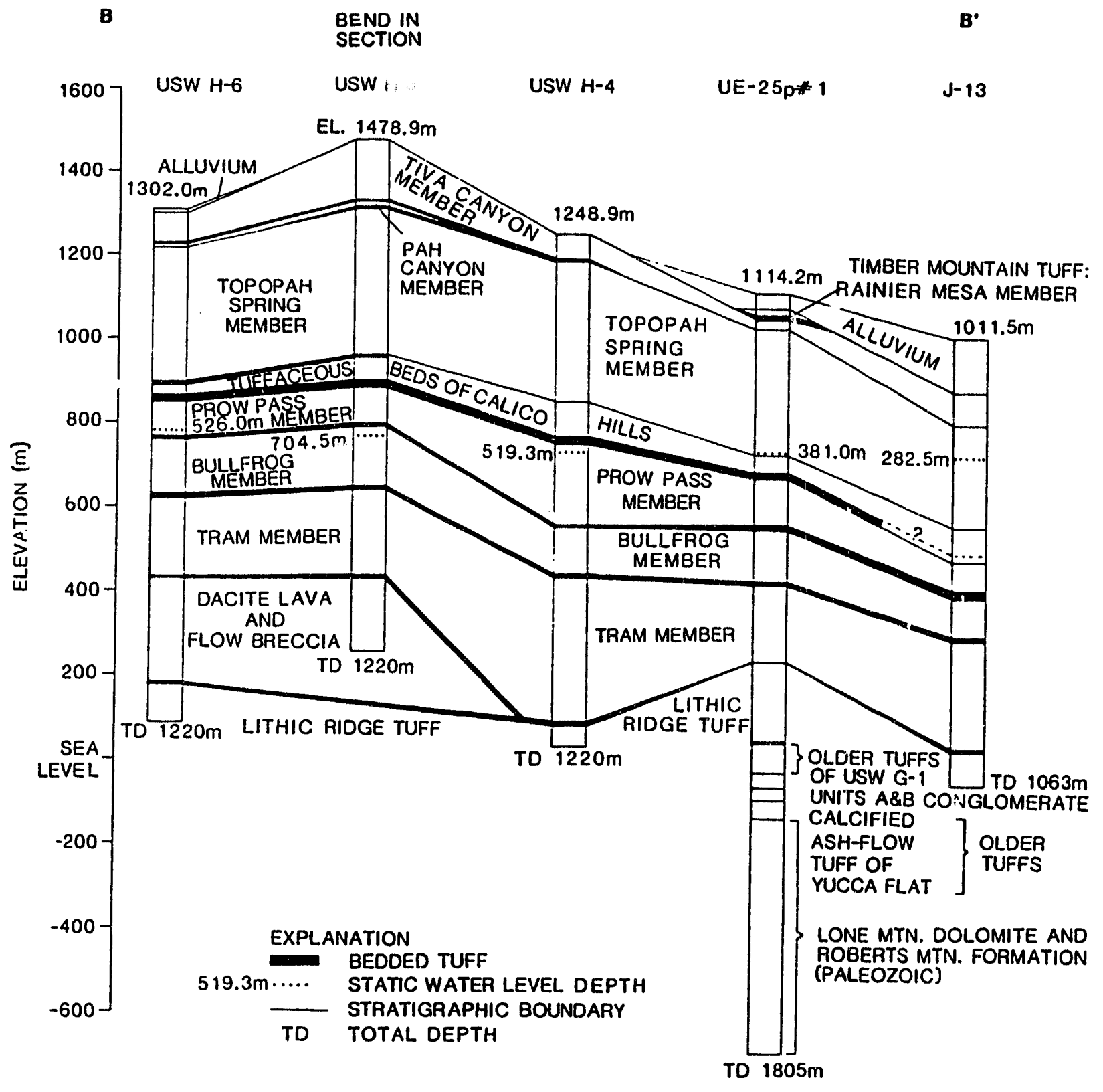

REFERENCES

H-6: CRAIG et al. (1983)

H-5: BENTLEY et al. (1983)

H-4: WHITFIELD et al. (1984)

p 1: CRAIG \& JOHNSON (1984)

HORIZONTAL SCALE

J-13: THORDARSON (1983)

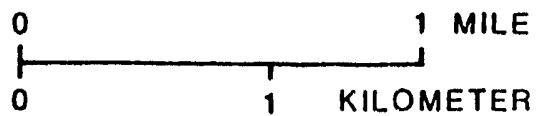

Figure 2b. East-west stratigraphic correlation between selected drill holes at Yucca Mountain. Vertical:horizontal scale $=2.5: 1$. After U.S. Department of Energy (1988). 
Table 2. Water table location, total Calico Hills nonwelded unit thickness and thickness of unsaturated Calico Hills nonwelded unit".

\section{Water Table Location}

Drill stratigraphic Hole Unit

Depth (m)
Total

Thickness Total Saturated Thickness

+ Unsat. (m)
Unsat. (m)

\section{Northern Half of Proposed Repository Block}

$\begin{array}{llllll}\text { UE-25 a\#1 Calico Hills } & 469.4^{\text {b }} & 728.8 & 360.6 & 67.9 \\ \text { UE-25 b\#1 Calico Hills } & 470.6 & 730.9 & 382.0 & 65.2 \\ \text { USW G-1 } & \text { Prow Pass } & 571.1 & 754.2 & 331.1 & 157.0 \\ \text { USW G-4 } & \text { Prow Pass } & 539.5 & 730.0 & 309.7 & 126.9 \\ \text { USW H-1 } & \text { Prow Pass } & 572.1 & 730.9 & 367.0 & 118.1 \\ \text { USW H-5 } & \text { Bullfrog } & 704.2 & 774.7 & 291.1 & 199.8\end{array}$

Southern Half of Proposed Repository Block

$\begin{array}{llllll}\text { USW GU-3 } & \text { Bullfrog } & 750.3 & 730.2 & 244.1 & 244.1 \\ \text { USW H-3 } & \text { Bullfrog } & 750.8^{c} & 732.4 & 228.0 & 228.0 \\ \text { USW H-4 } & \text { Prow Pass } & 518.7 & 729.8 & 391.1 & 147.8 \\ \text { USW WT-2 } & \text { Prow Pass } & 571.0 & 730.3 & 231.0+ & 174.0\end{array}$

- Water table depths and elevations from U. S. Department of Energy (1988) except where noted. Thickness of units determined from sources indicated in Table 2 .

b Water level from Spengler et al., 1979. Value represents an average of four measurements.

c Water lavel from Thordarson et al., 1984. 
Table 3. Definition of unsaturated-zone hydrogeologic units and correlation with rock-stratigraphic units. After U.S. Department of Energy (1988).

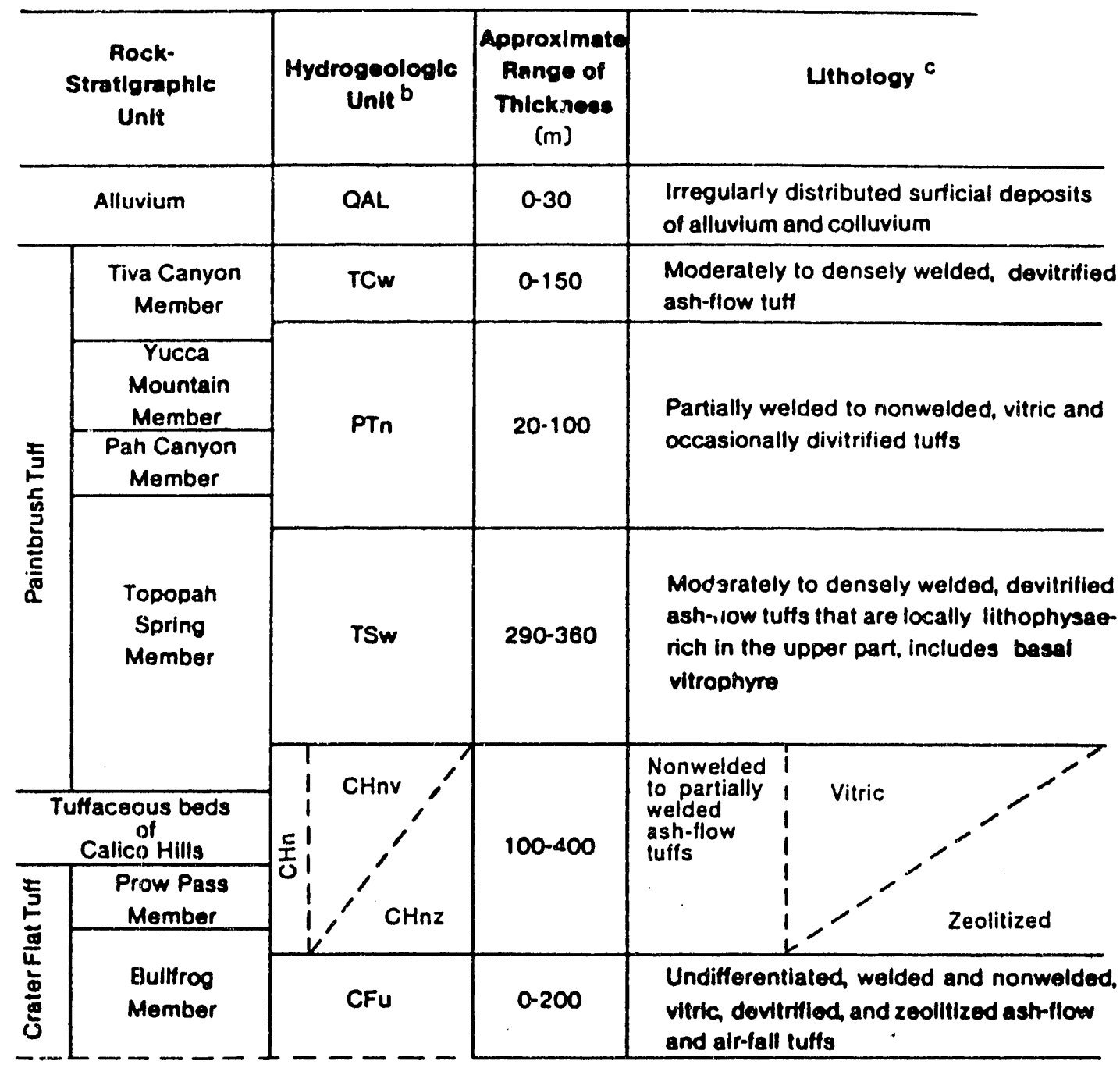

aSources: Montazer and Wilson (1984) except as noted.

bQAL = Quaternary Alluvium, $T C_{w}=$ Tiva Canyon welded unit, $P T_{n}=$ Paintbrush nonwelded unit, $\mathrm{TS}_{\mathbf{w}}=$ Topopah Spring welded unit, $\mathrm{CH}_{n}=$ Calico Hills nonwelded unit, $\mathrm{CH}_{n v}=$ Calico Hills nonwelded vitric unit, $\mathrm{CH}_{\mathrm{nz}}=$ Calico Hills nonwelded zeolitized unit, $\mathrm{CF}_{u}=$ Crater Flat undifferentiated unit.

CLithology summarized from Ortiz et al. (1985). 
A geochemical classification based on sorptive units not corresponding to the formal stratigraphic units was described by Bryant and Vaniman (1984). Cross-sections illustrating sorptive stratigraphy of Yucca Mountain are shown in Figures $3 \mathrm{a}$ and $3 \mathrm{~b}$. Percentages of minerals and glass observed in samples from selected boreholes are summarized graphically in Appendix $A$. The mineralogic data show that zeolites are present between the proposed repository horizon and the water table to some extent in each of the drill holes included. Thickness and degree of zeolitization varies from complete in the north (USW G-1, USW G4) and east (UE-25 a\#1) to partial in the south (USW H-3, USW GU3) and minimal in the west (USW H-5, USW $\mathrm{H}-6$ ). Ability of sorptive intervals to retard downward migration of some radionuclides depends on hydrologic and geochemical processes which are yet to be fully determined.

Fracture information from the Calico Hills nonwolded unit comes from borehole surveys, core samples and surface mapping of outcrops. Analysis of fracture frequency data from three vertical drill holes by Langkopf and Knirk (1986) provided estimates of fracture frequencies ranging from .2 to 2 fractures per cubic meter. They raport a fracture frequency of 1.2 fractures per cubic meter in the Tuffaceous Beds of the Calico Hills based on surface mapping in the region known as The Prow.

\section{HYDROLOGIC PROPERTIES}

A general summary of hydrogeologic characteristics of the unsaturated zone at Yucca Mountain is presented by Montazer and Wilson (1984). The previous authors attribute average parameters and average hydrologic behaviors to the designated hydrologic units. This report includes data which have become available since Montazer and Wilson's report. By making available sample statistics and a listing of the data, researchers are provided an overview of available data which may be useful in assessing current transport analysis strategies and directing those of the future. Appendix $B$ is a listing of compiled data including hydraulic conductivity, porosity, moisture content, saturation, pore-size distribution summary and saturation curve-fitting parameters. The data are generally organized first by drill hole and then by origin. Wherever possible, correlation between sample depth, lithology and alteration was made by referring to well logs and mineralogy available in the literature. Water chemistry data from the unsaturated Calico Hills nonwelded unit do not exist.

Table 4 summarizes the number of data from individual calico Hills nonwelded unit samples or subsamples for each drill hole included in Appendices $A$ and $B$ (i.e., two porosity measurements on the same sample or subsample are counted as a single data 


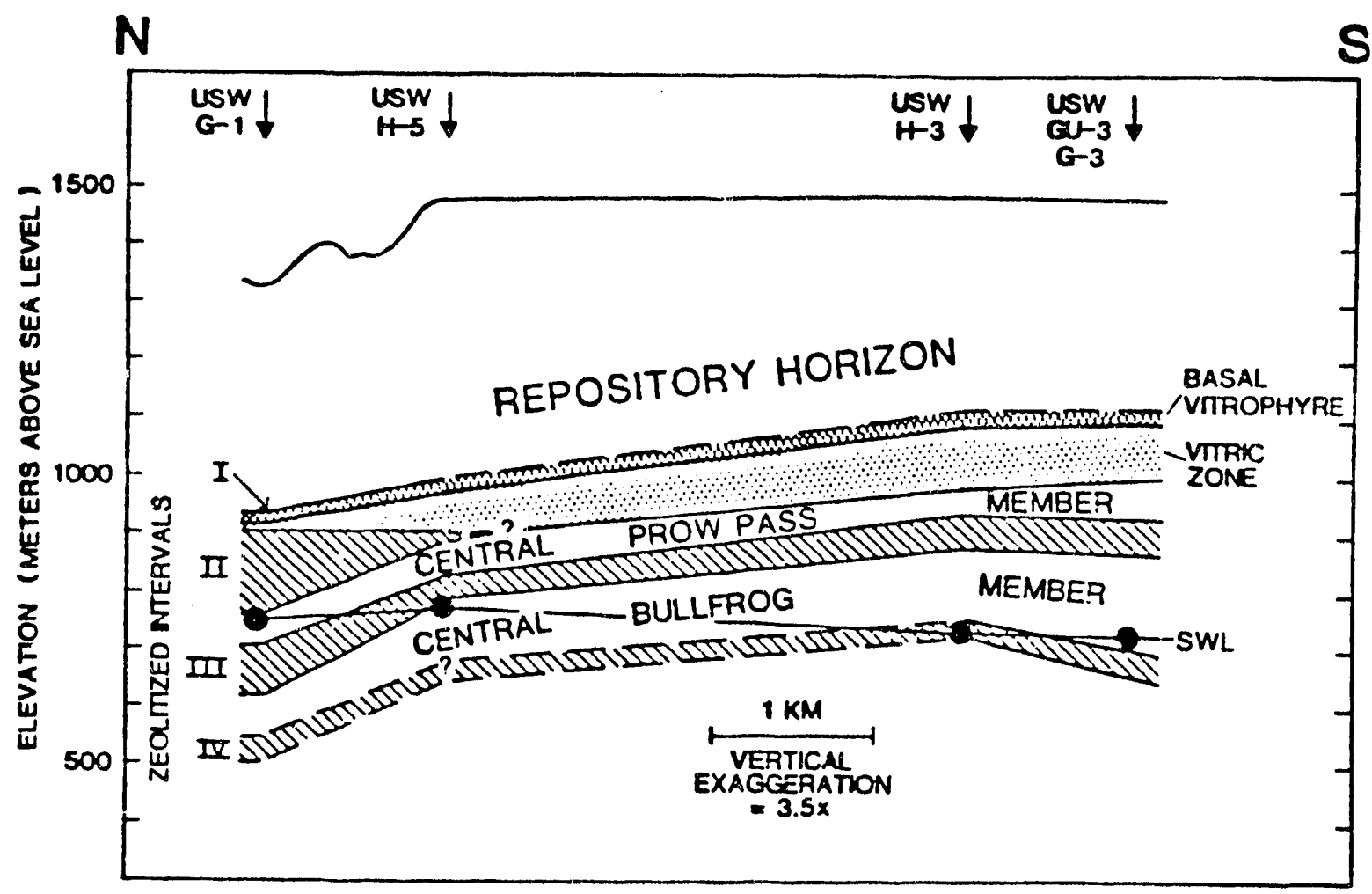

Figure 3a. Sorptive stratigraphy of Yucca Mountain. (Bryant and Vaniman, 1984). After Tien et al. (1985).

Zeolitized tuff

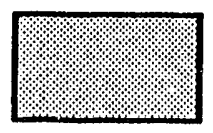

Vitric tuff

Basal vitrophyre 


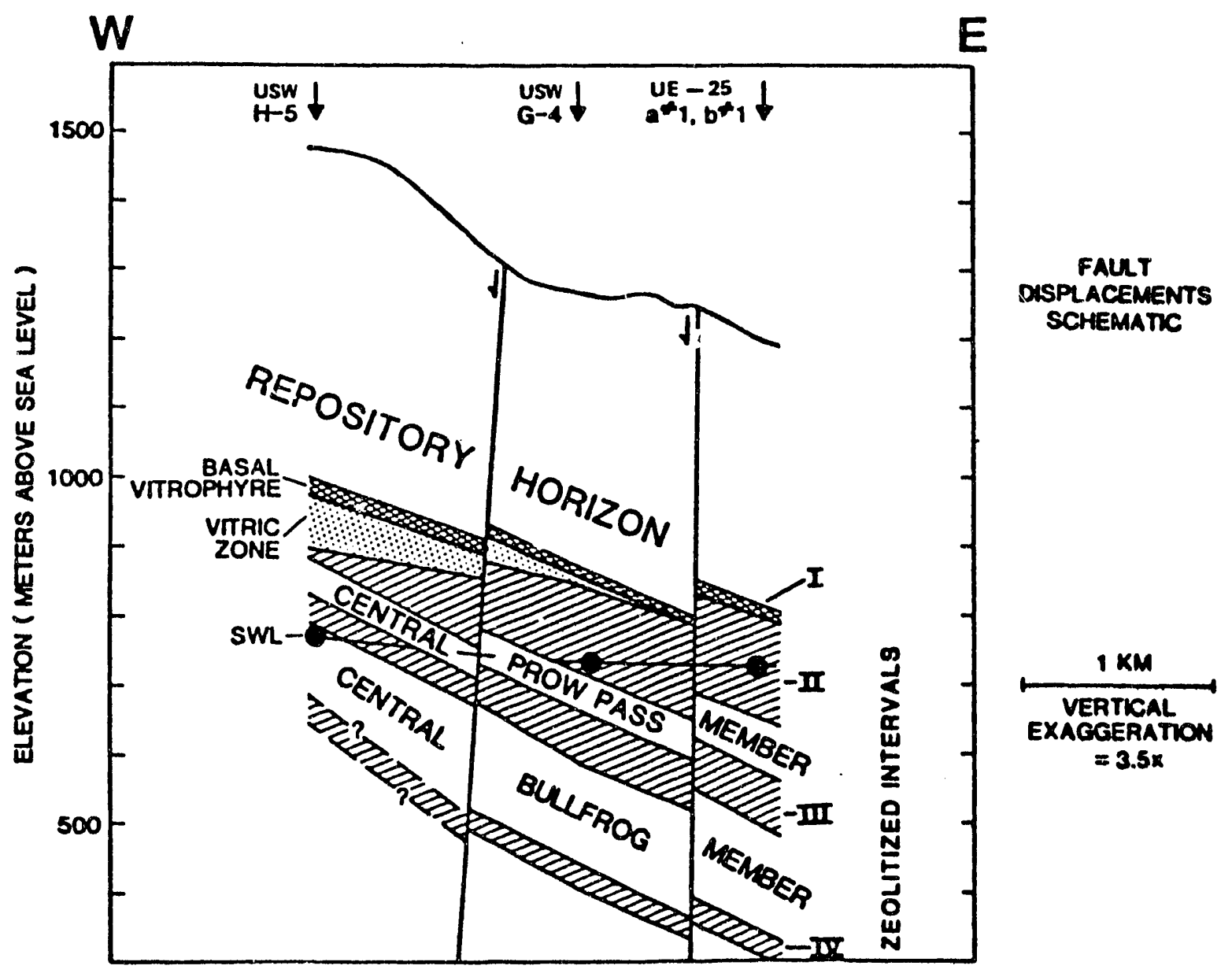

Figure 3b. Sorptive stratigraphy of Yucca Mountain. (Bryant and Vaniman, 1984). After Tien et al. (1985).
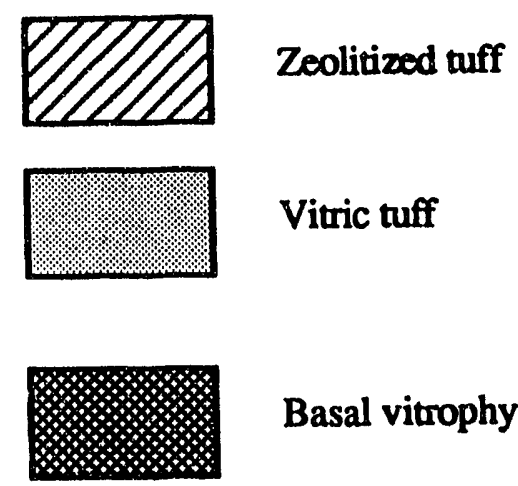

Basal vitrophyre 
Table 4. Number of measurements on different samples or subsamples by drill hole.

Hydraulic Saturation PoreDrill Conductivity Poro- Satur- Miner- Curve-Fit Size Hole Lab. Field sity ation alogy Parameters Dist.

Northern Half of Proposed Repository Block

$\begin{array}{lrrrrllr}\text { UE-25 a\#.1 } & 18 & 0 & 45 & 42 & \text { yes } & 0 & 0 \\ \text { UE-25 b\#1 } & 5 & 11 & 5 & 5 & \text { partial } & 0 & 0 \\ \text { USW G-1 } & 19 & 0 & 30 & 22 & \text { yes } & 17 & 11 \\ \text { USW G-4 } & 56 & 7 & 68 & 23 & \text { yes } & 37 & 15 \\ \text { USW H-1 } & 12 & 13 & 14 & 14 & \text { no } & 0 & 0 \\ \text { USW H-5 } & 0 & 0 & 0 & 0 & \text { yes } & 0 & 0\end{array}$

Southern Half of Proposed Repository Block

$\begin{array}{lccccccc}\text { USW GU-3 } & 20 & 0 & 36 & 24 & \text { yes } & 12 & 9 \\ \text { USW H-3 } & 0 & 0 & 0 & 0 & \text { yes } & 0 & 0 \\ \text { USW H-4 } & 0 & 7 & 0 & 0 & \text { yes } & 0 & 0 \\ \text { USW WT-2 } & 0 & 0 & 0 & 0 & \text { yes } & 0 & 0\end{array}$

Drill Holes Outside Proposed Repository Block

$\begin{array}{cccccccc}\text { UE-25 P\#1 } & 0 & 6 & 0 & 0 & \text { yes } & 0 & 0 \\ \text { USW G-2 } & 0 & 0 & 0 & 0 & \text { yes } & 0 & 0 \\ \text { USW H-6 } & 0 & 0 & 0 & 0 & \text { yes } & 0 & 0 \\ \text { USW J-13 } & 1 & 12 & 3 & 2 & \text { yes } & 0 & 0\end{array}$


point, but single porosity measurements from each of two subsamples of the same sample are counted as two data points). Table 4 shows that except for drill hole USW GU-3, located over one and a half kilometers south of the proposed peri.leter drift boundary, at this time southern parts of the repository exploration block are poorly represented in terms of hydrologic property measurements.

\subsection{Saturated Hydraulic Conductivity}

Permeability is a property of a porous medium that characterizes the ability of the medium to transmit a fluid (units $\mathrm{L}^{2}$ ). Hydraulic conductivity reflects the ability of a medium to transmit a particular fluid, i.e., properties of the fluid are incorporated into the parameter (units $L / t$ ). The relationship between them is expressed as

$$
K=\frac{\rho g k}{\mu}
$$

where

and

$$
\begin{aligned}
& \mathbf{R}=\text { hydraulic conductivity }(\mathrm{L} / \mathrm{t}) \\
& \mathbf{k}=\text { permeability }\left(\mathrm{L}^{2}\right) \\
& \rho=\text { fluid density }\left(\mathrm{M} / \mathrm{L}^{3}\right) \\
& \mathbf{g}=\text { acceleration of gravity }\left(\mathrm{L} / \mathrm{t}^{2}\right) \\
& \mu=\text { dynamic viscosity }(\mathrm{M} / \mathrm{L} t)
\end{aligned}
$$

$$
\begin{aligned}
& \mathrm{L}=\text { length } \\
& \mathrm{t}=\mathrm{time} \\
& \mathrm{M}=\text { mass }
\end{aligned}
$$

In this discussion, hydraulic conductivity will always refer to a medium saturated with water (density $=1 \mathrm{~g} / \mathrm{cm}^{3}$ ) in the standard range of temperature $\left(15^{\circ} \mathrm{C}-20^{\circ} \mathrm{C}\right)$ at atmospheric pressure. Permeability and hydraulic conductivity will be referenced interchangeably.

Numerous studies have led researchers to conclude that hydraulic conductivity in most geologic media is distributed approximately log-normally (Freeze, 1975). For this reason, statistical parameters of hydraulic conductivity data are often determined in log space. Sample statistics of hydraulic conductivity data in both log space and real space are presented here. The geometric mean is generally taken to be a more representative value than the arithmetic mean for use in deterministic calculations, depending on factors including the geometry and dimensionality of the flow field. For a further discussion the reader is referred to de Marsily (1986). 
Application of a classical contiruum approach to flow in porous media requires the definition of parameters that express the average behavior of a system reiative to some property of interest. The continuum approach is fundamentally rooted in the concept of a representative elementary volume (REV). Whether or not laboratory permeability data obtained at the one to six centimeter scale or aquifer test data obtained at the meter to tens of meters scale meet the REV criteria for matrix and fracture-matrix respectively is a critical question that is yet to be answered.

Laboratory samples, at the centineter scale, are usually homogeneous in the sense that as a rule the physical properties governing fluid flow through the sample do not change substantially within the length scale of the sample. Flow at laboratory scales is assumed to be well approximated as onedimensional flow. At larger scales, such as those of aquifer tests, flow is more likely to be three-dimensional. Saturated flow measurements obtained at larger scales incorporate a larger range of variability, including both the effects of matrix variability and the influence of fractures and macropores. Field heterogeneities in hydraulic conductivity have been found to play an important role in the dispersion of solutes in porous media. since it is impossible to know the hydraulic conductivity at every point in space as required by deterministic methods, efforts to describe heterogeneity in porous media have focused on stochastic approaches (Gelhar and Axness, 1983; Neuman, 1987; Dagan 1987). Understanding the effects of that variability on solute transport is essential to the understanding and prediction of field phenomena (Dagan, 1989).

Measurements of saturated hydraulic conductivity in the Calico Hills nonwelded unit from the laboratory and from aquifer tests are summarized in Appendix B. Data are presented in both permeability and hydraulic conductivity units for the convenience of the reader. Lithology of samples was inferred from the drill hole logs referenced in Table 1 .

\section{1.a. Laboratory Measurements}

Laboratory samples were taken from core in both unsaturated and saturated parts of boreholes. Laboratory test data in Appendix $B$ are from cylindrical samples having the dimensions shown in Table 5. Dagan (1986) describes the laboratory scale as between $10^{-1}$ to $10^{0} \mathrm{~m}$ in length. By those criteria, measurements on the samples summarized in Table 5 may be considered to be at sub-laboratory scales. The difference in sample size is related to the low permeability of the rock samples from Yucca Mountain compared with higher permeability in soil cores more typically tested in the laboratory. In both cases, the hydraulic conductivity data obtained in the laboratory represent matrix 
Table 5. Number of samples, dimensions and source of laboratory hydraulic conductivity data from selected drill holes near Yucca Mountain, Nevada.

Drill No.

Hole Samples Dimensions Source

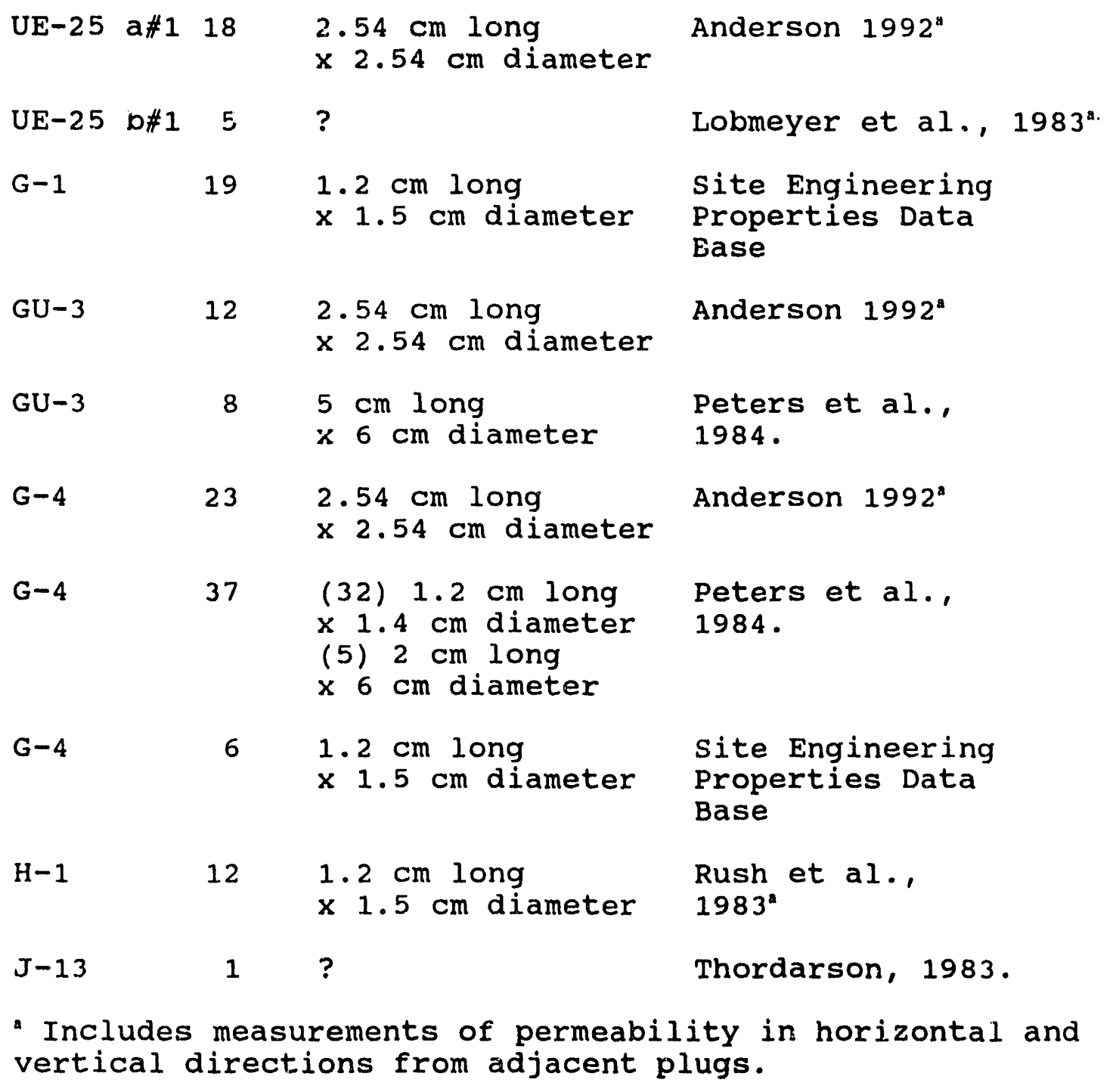


values from samples which may or may not be representative of the medium in a continuum sense. Efflects of fractures anc other forms of potential fast flow paths are generally not incorporated in the measurements. Likewise, friable media too fragile for sample preparation are not represented by the data. These data may be useful as input parameter guidelines for flow models, but only at saturations where fracture flow does not occur. Also, it should be recognized that omission of friable samples biases the laboratory-scale sample statistics. Friable samples may have higher than average saturated permeabilities and more steeply sloping moisture characteristic curves, with correspondingly lower unsaturated permeabilities over a wide range of moisture contents, than more intact tuffs.

Sample statistics of the laboratory hydraulic conductivities and their base-ten logarithms were determined for vitric tuff, devitrified tuff, zeolitic tuff and the combined data set. Table 6 summarizes the results of the statistical analysis. Data from devitrified, zeolitic sample intervals were inclucled with zeolitic data. Samples from vapor phase tuffs were omitted. Lognormal probability plots of devitrified, vitric and zeolitic data are shown in Figure 4. Figure 5 is a lognormal probability plot of the entire laboratory hydraulic conductivity data set. The Weibull plotting formula was used to determine plotting position or cumulative probability for the probability plots.

The sample statistics in Table 6 show that the geometric mean matrix permeabilities of vitric and devitrified tuffs are close and that both means are nearly two orders of magnitude greater than the geometric mean permeability of zeolitic tuffs. The skewness coefficients indicate that the log permeabilities more closely approximate a normal distribution than do the data in real space. Figure 4 supports these observations. Devitrified and zeolitic data lognormal probability plots are roughly linear. Vitric data plot more erratically, but this may be due to insufficient data points. It should be noted in Figure 4 that while the means of the devitrified and vitric data are very close in log space, the distributions are relatively dissimilar, although again this may result from insufficient vitric data points. The roughly linear lognormal probability plot of the combined data confirms the approximate loonormal distribution of hydraulic conductivity in the calicr Hills nonwelded unit based on this data set, but does nut address the question of spatial correlation of the data.

The coefficient of variation suggests that hydraulic conductivity is most variable in the vitric tuffs. However, more data are needed, particularly from the vitric tuffs. Using mineralogy from Appendix $A$ in the sampling intervals, a correlation of -0.613 was found between percent zeolites and log matrix hydraulic conductivity. Correlation between degree of welding and log hydraulic conductivity is 0.428 . The vitric tuff 
Table 6. Sample statistics of laboratory hydraulic conductivity data for vitric, devitrified and zeolitic tuffs and for lumped data.

$\frac{\text { Base-Ten Log Hydraulic conductivity }}{\text { (originally in } \mathrm{m} / \mathrm{s} \text { ) }}$

Vitric Devitrified Zeolitic _All

\begin{tabular}{lrrrr} 
No. Samples & \multicolumn{1}{c}{17} & 54 & 83 & \multicolumn{1}{c}{154} \\
Minimum & -10.70 & -9.80 & -13.63 & -13.63 \\
Maximum & -6.42 & -5.65 & -8.00 & -5.65 \\
Range & 4.28 & 4.16 & 5.63 & 7.98 \\
Arith. Mean & -8.40 & -8.37 & -10.16 & -9.34 \\
Median & -8.50 & -8.60 & -10.30 & -9.24 \\
Variance & 2.57 & 0.84 & 1.43 & 2.12 \\
Skewness & -0.11 & 0.77 & -0.32 & -0.10 \\
C.V. & -0.19 & -0.11 & -0.12 & -0.16
\end{tabular}

Hydraulic Conductivity in Meters per second

Vitric Devitrified Zeolitic

No. Samples 17

Minimum

Maximum

Range

Arith. Mean

Geom. Mean

Median

Variance

Skewness

C.V.a
$1.99 e-11$

$3.76 e-07$

$3.76 e-07$

8. $80 \mathrm{e}-08$

3. $95 e-09$

3. $15 e-09$

$1.73 e-14$

1.18

1.49
54

1. $57 e-10$

2. $25 e-06$

2. $25 e-06$

$7.08 e-08$

$4.28 e-09$

2. 50e-09

$9.95 e-14$

6.35

4.45
83

2. $37 e-14$

$1.00 e-08$

$1.00 e-08$

8. $07 e-10$

$6.90 e-11$

5. $06 \mathrm{e}-11$

3. $40 e-18$

3.41

2.28
154

$2.37 e-14$
$2.25 e-06$
$2.25 e-06$
$3.50 e-08$
$4.59 e-10$
$5.79 e-10$
$3 \cdot 77 e-14$
$9 \cdot 98$
$5 \cdot 55$

a Coefficient of variation. 


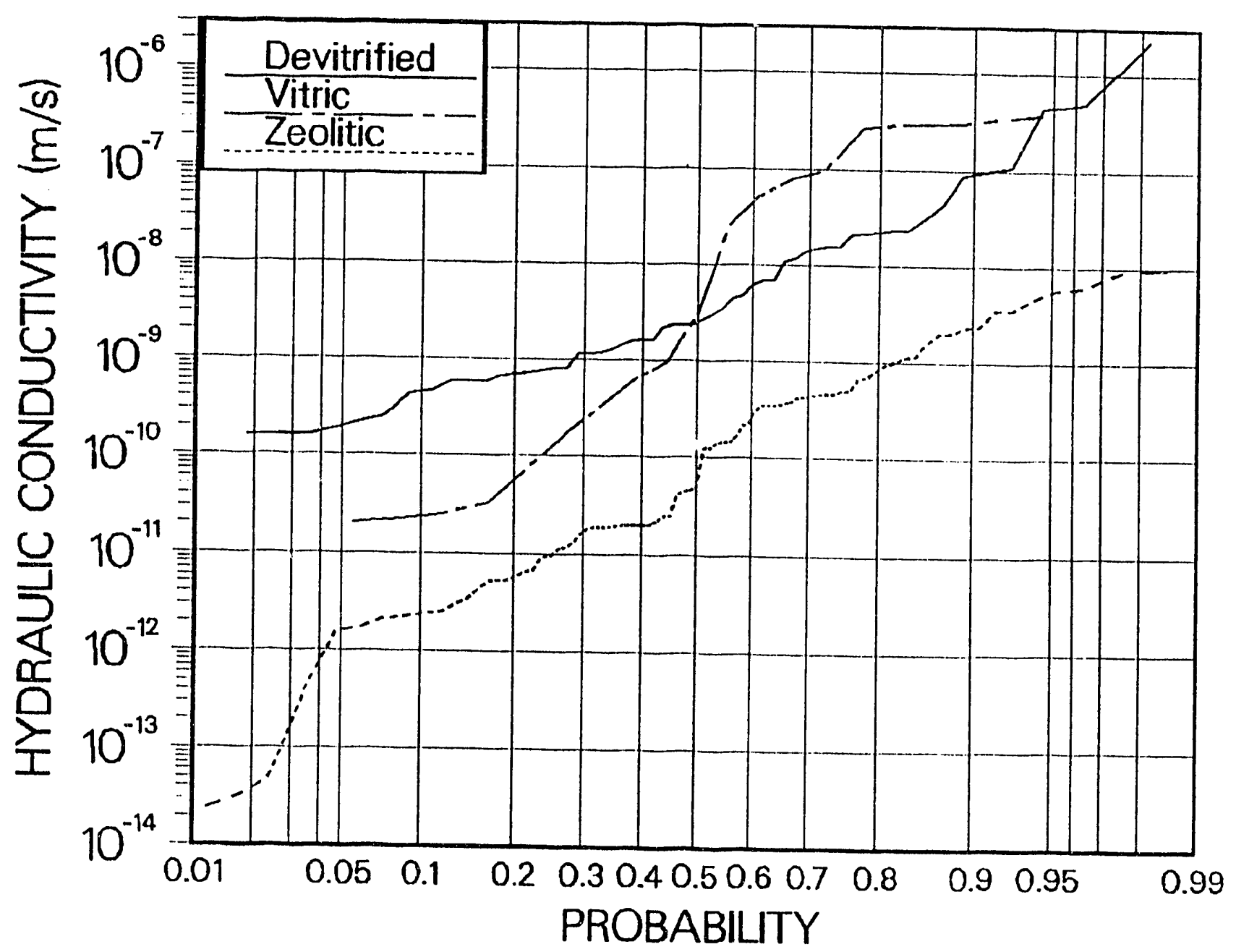

Figure 4. Log-normal probability plot of devitrified, vitric and zeolitic laboratory hydraulic conductivity data. 


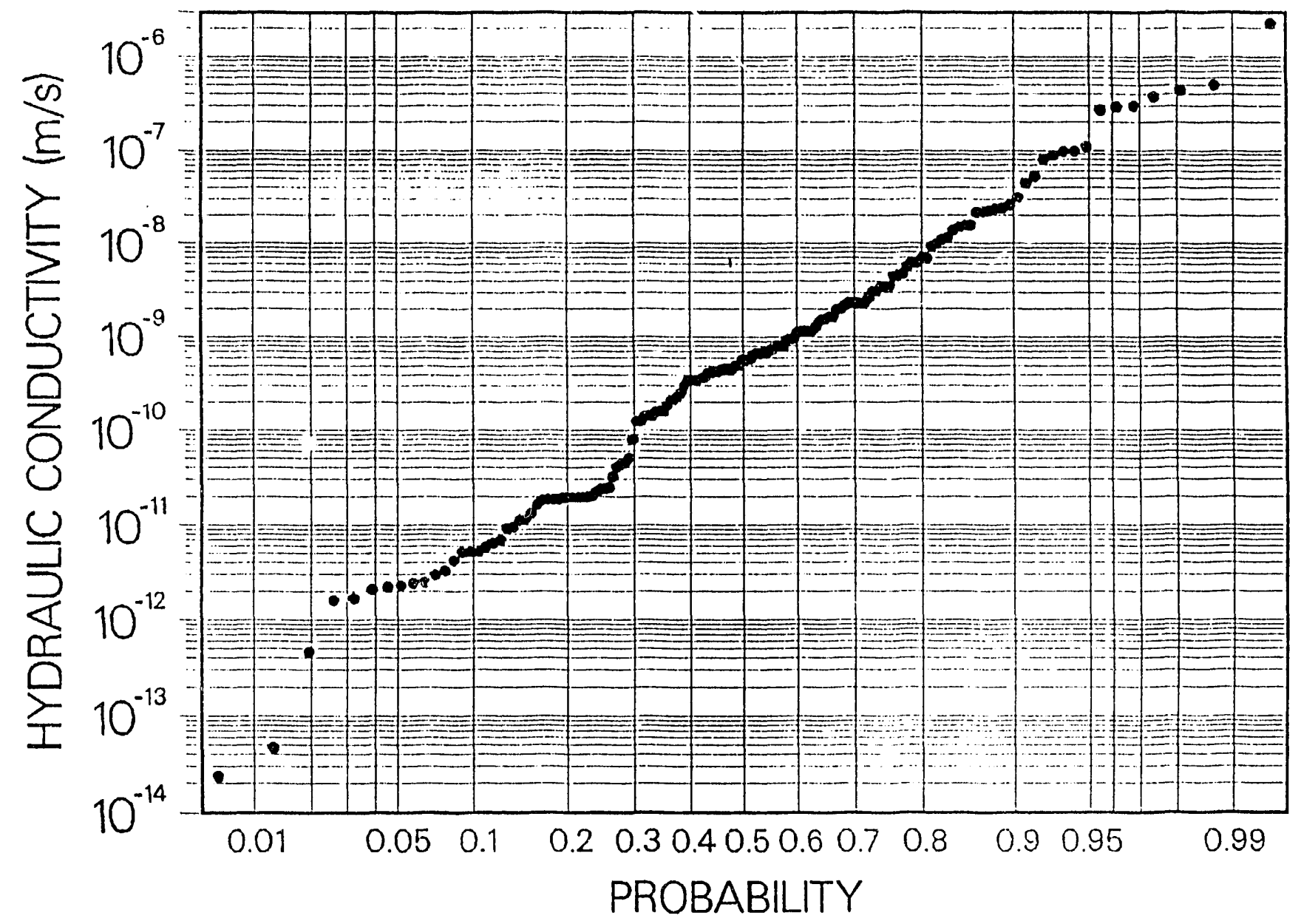

Figure 5. Log-normal probability plot of all laboratory hydraulic conductivity data. 
geometric mean hydraulic conductivity, $3.95 \mathrm{e}-09 \mathrm{~m} / \mathrm{s}$, based on 17 samples, is nearly an order of magnitude smaller than that reported by Montazer and Wilson (1984) of $4.62 \mathrm{e}-08 \mathrm{~m} / \mathrm{s}$, based on four samples. Montazer and Wilson (1984) combined data from devitrified tuff and zeolitic tuff and reported a geometric mean hydraulic conductivity value of $9.26 \mathrm{e}-11 \mathrm{~m} / \mathrm{s}(22$ samples), only slightly greater than that reported here for zeolitic tuffs in Table 6, 6.90e-11 m/s.

The implications of the statistics shown in Table 6 are twofold. It is apparent that hydraulic conductivity varies considerably within each of the three groups. Values span between four and six orders of magnitude for the three groups. However, as shown in Table 7 for zeolitic tuffs, variability within indivjdual data sets from each drill hole is considerably smaller, with the exception of the measurements of peters et al. (1984) in USW G-4. The measurements of Peters et al. (1984) from USW G-4 were obtained using samples of two different sizes and two different testing methods. Reduced variability within drill holes reflects near field correlation of matrix properties relative to the larger repository scale. As a rule, variability increases with separation distance between sampling points. Some part of the observed variability in measured hydraulic conductivity almost surely originates in differences in sample size, sample handling and test methods between researchers. This contribution has not been quantified but most likely has an important but obscured role in the data currently available. Measurements from samples of the same size and handling history obtained by the same methods minimize this added source of variability, but introduce the possibility of bias in the results.

Availability of three sets of data from drill hole USW G-4 allows comparison of values derived by different researchers for the interval of zeolitized calico Hills nonwelded tuff between about 429 and $520 \mathrm{~m}$ depth. The results of a comparison show that values reported by Peters et al. (1984) and in the site Engineering Properties Data Base (1989) are an average of 2.3 orders of magnitude smaller than those reported by Anderson (1992). While data points are too few in number to draw conclusions, a question is raised regarding the source of the apparent differences in the sets of laboratory hydraulic conductivity values for USW G-4. Similar questions may be asked about the data sets for individual drill holes. How much of the variability is real and how much is an artifact of size, removal, handling and testing procedures? Differences in measured values may be a result of testing sample volumes smaller than a representative elementary volume. The lower size limit of an REV can only be determined by careful testing at different scales. other sources of differences in reported values may be related to pretest handling of samples, variability in test fluids, or testing methods. The lowest reported permeabilities in USW G-4 
Table 7. Base-ten logarithm of laboratory hydraulic conductivity (K) measurements for zeolitic tuffs and range, by drill hole. Originally in meters per second.

(v)=vertical; (h)=horizontal.

$\begin{array}{cccc}\begin{array}{c}\text { Depth } \\ (\mathrm{m})\end{array} & \begin{array}{l}\text { Lith- } \\ \text { Ology }^{1}\end{array} \log _{10} \mathrm{~K} & \begin{array}{c}\text { Range } \\ \log _{10} \mathrm{~K}\end{array}\end{array}$ Source

$\mathrm{UE}-25$ a\#1

\begin{tabular}{|c|c|c|c|c|}
\hline $\begin{array}{l}462.1 \\
477.9 \\
499.3 \\
530.7 \\
545.9 \\
658.1 \\
670.9\end{array}$ & $\begin{array}{l}n / d v, z \\
n / d v, z \\
n / d v, z \\
n / d v z \\
b t / z \\
p / d v, z \\
p / d v, z\end{array}$ & $\begin{array}{r}-9.84466 \\
-8.63451 \\
-8.45346 \\
-9.29930 \\
-10.36151 \\
-8.94885 \\
-8.00218\end{array}$ & 2.36 & $\begin{array}{l}\text { Anderson (1981) } \\
\text { length }=2.54 \mathrm{~cm} \\
\text { diameter }=2.54 \mathrm{~cm} \\
\text { volume }=12.84 \mathrm{~cm}^{3}\end{array}$ \\
\hline
\end{tabular}

$\mathrm{UE}-25 \quad \mathrm{~b} \# 1$

\begin{tabular}{|c|c|c|c|c|}
\hline $\begin{array}{l}479 \cdot 3 \\
479.3 \\
679 \cdot 5 \\
679 \cdot 5\end{array}$ & $\begin{array}{l}\mathrm{n} / \mathrm{z} \\
\mathrm{n} / \mathrm{z} \\
\mathrm{pm} / \mathrm{dv}, \mathrm{z} \\
\mathrm{pm} / \mathrm{dv}, \mathrm{z}\end{array}$ & $\begin{array}{r}-9.36856(\mathrm{~h}) \\
-8.70553(\mathrm{v}) \\
-11.01728(\mathrm{~h}) \\
-10.70553(\mathrm{v})\end{array}$ & 2.31 & $\begin{array}{l}\text { Lobmeyer et al. (1983) } \\
\text { sample size unknown }\end{array}$ \\
\hline
\end{tabular}

USW G-1

$\begin{array}{lll}457.1 & \mathrm{n} / \mathrm{dv}, \mathrm{z} & -10.93554 \\ 457.1 & \mathrm{n} / \mathrm{dv}, \mathrm{z} & -10.73049 \\ 499.0 & \mathrm{n} / \mathrm{z} & -10.71220 \\ 499.0 & \mathrm{n} / \mathrm{z} & -11.03480 \\ 534.0 & \mathrm{bt} / \mathrm{z}, \mathrm{s} & -10.94692 \\ 534.0 & \mathrm{bt} / \mathrm{z}, \mathrm{s} & -10.78516 \\ 542.4 & \mathrm{bt} / \mathrm{z}, \mathrm{s} & -11.65561 \\ 542.4 & \mathrm{bt} / \mathrm{z}, \mathrm{s} & -11.68194 \\ 545.5 & \mathrm{bt} / \mathrm{z}, \mathrm{s} & -11.28233 \\ 545.5 & \mathrm{bt} / \mathrm{z}, \mathrm{s} & -11.28233 \\ 554.9 & \mathrm{p} / \mathrm{dv}, \mathrm{z} & -10.39041 \\ 554.9 & \mathrm{p} / \mathrm{dv}, \mathrm{z} & -10.34486\end{array}$

1.34 Site Engineering Properties Data Base length $=1.2 \mathrm{cin}$ diameter $=1.4 \mathrm{~cm}$ volume $=1.85 \mathrm{~cm}^{3}$

USW $\mathrm{H}-1$

\begin{tabular}{|c|c|c|c|c|}
\hline $\begin{array}{l}790.0 \\
790.0 \\
791.0 \\
791.0 \\
792.0 \\
792.0\end{array}$ & $\begin{array}{l}\mathrm{nm} / \mathrm{dv}, \mathrm{z} \\
\mathrm{nm} / \mathrm{dv}, \mathrm{z} \\
\mathrm{nm} / \mathrm{dv}, \mathrm{z} \\
\mathrm{nm} / \mathrm{dv}, \mathrm{z} \\
\mathrm{nm} / \mathrm{dv}, \mathrm{z} \\
\mathrm{nm} / \mathrm{dv}, \mathrm{z}\end{array}$ & $\begin{array}{l}-9.33442(\mathrm{v}) \\
-9.33442(\mathrm{~h}) \\
-9.03339(\mathrm{v}) \\
-9.15864(\mathrm{~h}) \\
-9.45967(\mathrm{v}) \\
-9.09151(\mathrm{~h})\end{array}$ & 0.43 & $\begin{array}{l}\text { Rush et al. (1983) } \\
\text { sample size unknown }\end{array}$ \\
\hline
\end{tabular}

Continued on next page 
Table 7 ., continued

USW G-4

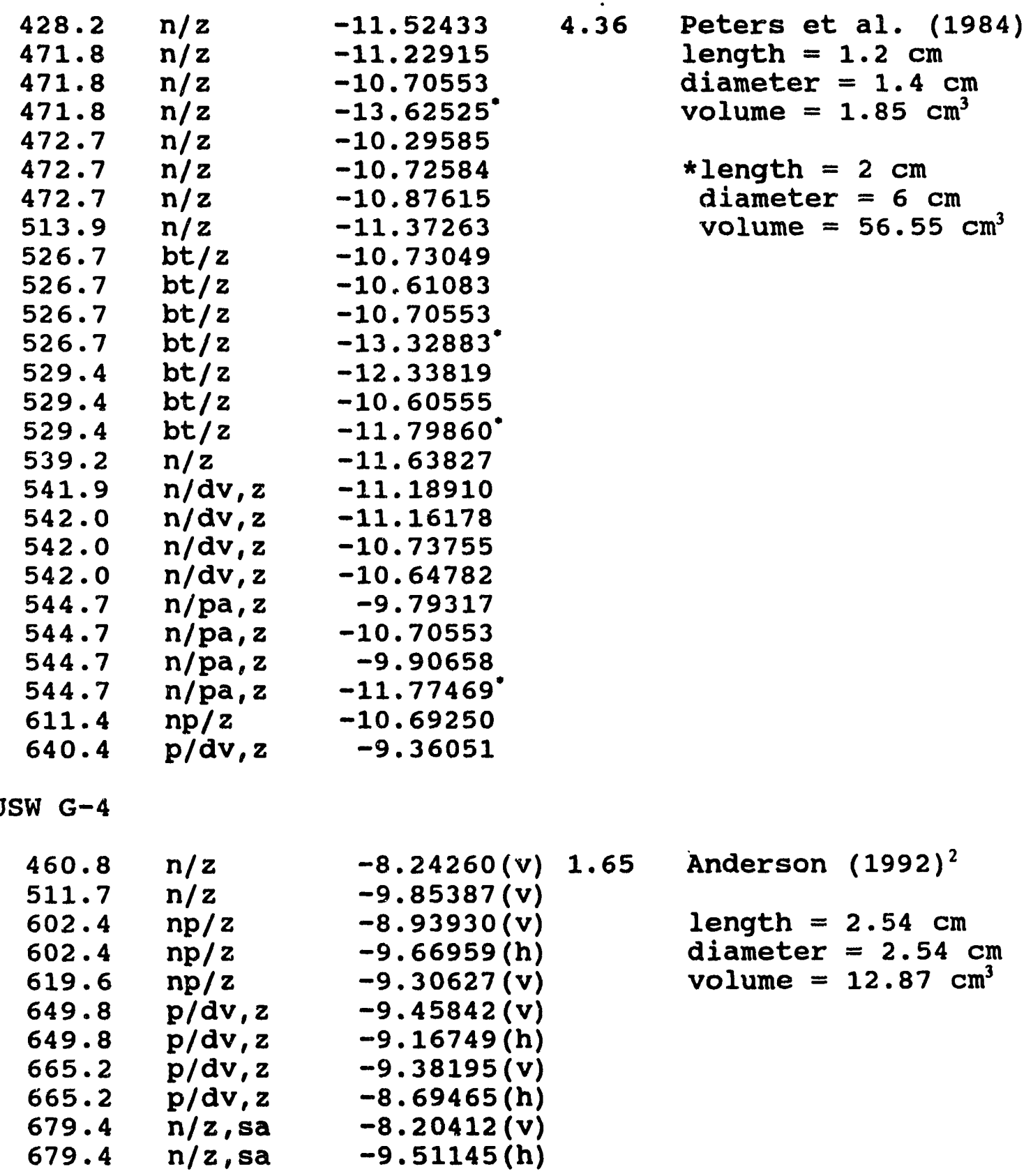

USW G-4

$\begin{array}{lllll}454.1 & \mathrm{n} / \mathrm{z} & -11.60206 & 0.33 & \text { site Engineering } \\ 486.7 & \mathrm{n} / \mathrm{z} & -11.61439 & & \text { Properties Data Base } \\ 522.6 & \mathrm{bt} / \mathrm{z} & -11.48017 & \text { length }=1.2 \mathrm{~cm} \\ 532.4 & \mathrm{bt} / \mathrm{z} & -11.28483 & \text { diameter }=1.5 \mathrm{~cm} \\ & & & \text { volume }=2.12 \mathrm{~cm}^{3}\end{array}$


Table $7 .$, continued

USW GU-3

$\begin{array}{lllll}552.9 & \mathrm{p} / \mathrm{dv}, \mathrm{z} & -8.81531 & 1.09 & \text { Anderson }(1992) \\ 569.2 & \mathrm{p} / \mathrm{dv}, \mathrm{z} & -9.42251 & & \\ 569.2 & \mathrm{p} / \mathrm{dv}, \mathrm{z} & -9.44009 & & \text { length }=2.54 \mathrm{~cm} \\ 583.1 & \mathrm{p} / \mathrm{dv}, \mathrm{z} & -9.90309 & & \text { diameter }=2.54 \mathrm{~cm} \\ 597.1 & \mathrm{p} / \mathrm{dv}, \mathrm{z} & -9.84164 & & \text { volume }=12.87 \mathrm{~cm}^{3} \\ 612.3 & \mathrm{p} / \mathrm{z} & -9.00218 & & \end{array}$

1 Lithology from logs referenced in Table 1.

2 Vertical and horizontal data from adjacent plugs.

Key to lithology abbreviations:

1. Degree of welding precedes slash.

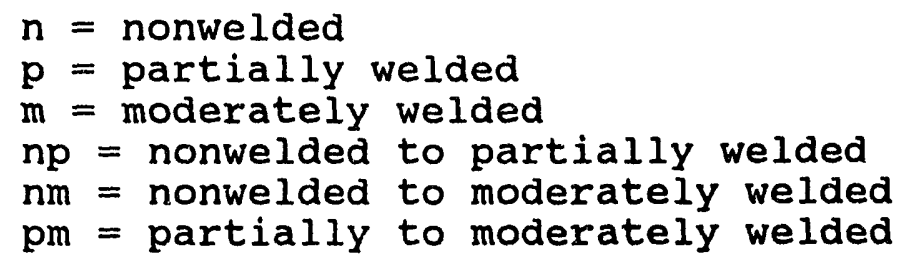

2. Alteration indicator follows slash.

$$
\begin{aligned}
& v=\text { vitric } \\
& z=\text { zeolitic } \\
& s z=\text { slightly zeolitic } \\
& d v=\text { devitrified } \\
& \text { pdv = partially devitrified } \\
& \mathrm{vp}=\text { vapor phase } \\
& \mathrm{a}=\text { argillic } \\
& \mathbf{s a}=\text { slightly argillic } \\
& \text { pa = partly argillic } \\
& \mathbf{s}=\text { silicified } \\
& \text { ps = partly silicified }
\end{aligned}
$$

3. bt $=$ bedded tuff

Example: $n p / d v, z=$ sample originates in nonwelded to partially welded interval which is devitrified and zeolitized. 
were measured on the largest samples. Sources of field variability include differences in degree of zeolitization, alteration history and the unique circumstances surrounding emplacement and subsequent events at individual sample locations. With this in mind, it is clear that additional work is called for to resolve questions related to existing laboratory permeability data from the Calico Hills nonwelded unit. It is essential to understand exactly what a given data set represents before applying it to a problem. Identification of correlations between properties such as degree of zeolitization and variability of hydraulic conductivity can be important aids in site performance assessment modeling.

The high variability observed in the hydraulic conductivity measurements points to a probable need for a stochastic approach in solute transport analysis in the matrix. Sample statistics also indicate that using matrix hydraulic conductivities of zeolitic tuffs for devitrified tuffs in simulations is not justified. Doing so could result in unrealistically low transport rates at Yucca Mountain when saturations are high and possibly the reverse when saturations are low, depending on the shape of the moisture characteristic curves.

\section{1.b. Aquifer Tests}

Data in Appendix B from aquifer tests represent intervals of a meter to tens of meters where the units of interest are saturated. Fifty-six data from test intervals in the calico Hills nonwelded hydrogeologic unit are listed in Appendix $B$. In addition to length of test interval, volume of rock influenced by aquifer tests varies with test duration, magnitude of induced gradients, effective porosity and hydraulic conductivity. All of the test intervals are in nonwelded to partially welded zeolitic and devitrified tuffs and bedded tuffs, except for a thin, moderately welded interval in USW H-4. None of the aquifer tests were conducted in vitric tuffs. Since many of the intervals spanned multiple horizons, it was not possible to separate data as was done for the laboratory samples. Sample statistics of the aquifer hydraulic conductivity measurements are shown in Table 8 . The zero and negative hydraulic conductivity values from drill hole USW $\mathrm{H}-1$ were omitted from the calculations. Figure 6 is a log-normal probability plot of the aquifer test data using the Weibull plotting position.

The aquifer test hydraulic conductivity data show that geometric mean hydraulic conductivity is from two to four orders of magnitude greater at field scales than at laboratory scales in the Calico Hills nonwelded hydrogeologic unit. Figure 6 shows that the data are approximately log-normally distributed. As was the case with the laboratory hydraulic conductivity data, the range of values spans nearly five orders of magnitude. 
Table 8. Sample statistics for aquifer test hydraulic conductivity data.

$\frac{\text { Base-Ten Log Hydrauilic Conductivity }}{\text { (originally in } \mathrm{m} / \mathrm{s} \text { ) }}$

No. Samples 56

Minimum $\quad-8.46$

Maximum $\quad-3.68$

Range 4.78

Arith. Mean -6.15

Median $\quad-6.36$

Variance $\quad 0.94$

Skewness $\quad 0.29$

C.V." $\quad-0.16$

Hydraulic Conductivity in Meters per second

No. Samples 56

Minimum

Maximum

$3.47 e-09$

Range

$2.08 e-04$

Arith. Mean

$2.08 e-04$

Geom. Mean

$7.50 e-06$

Median

$7.00 e-07$

Variance

Skewness

$4.40 e-07$

C.V."

$7.93 e-10$

6.63

3.75

- Coefficient of variation. 


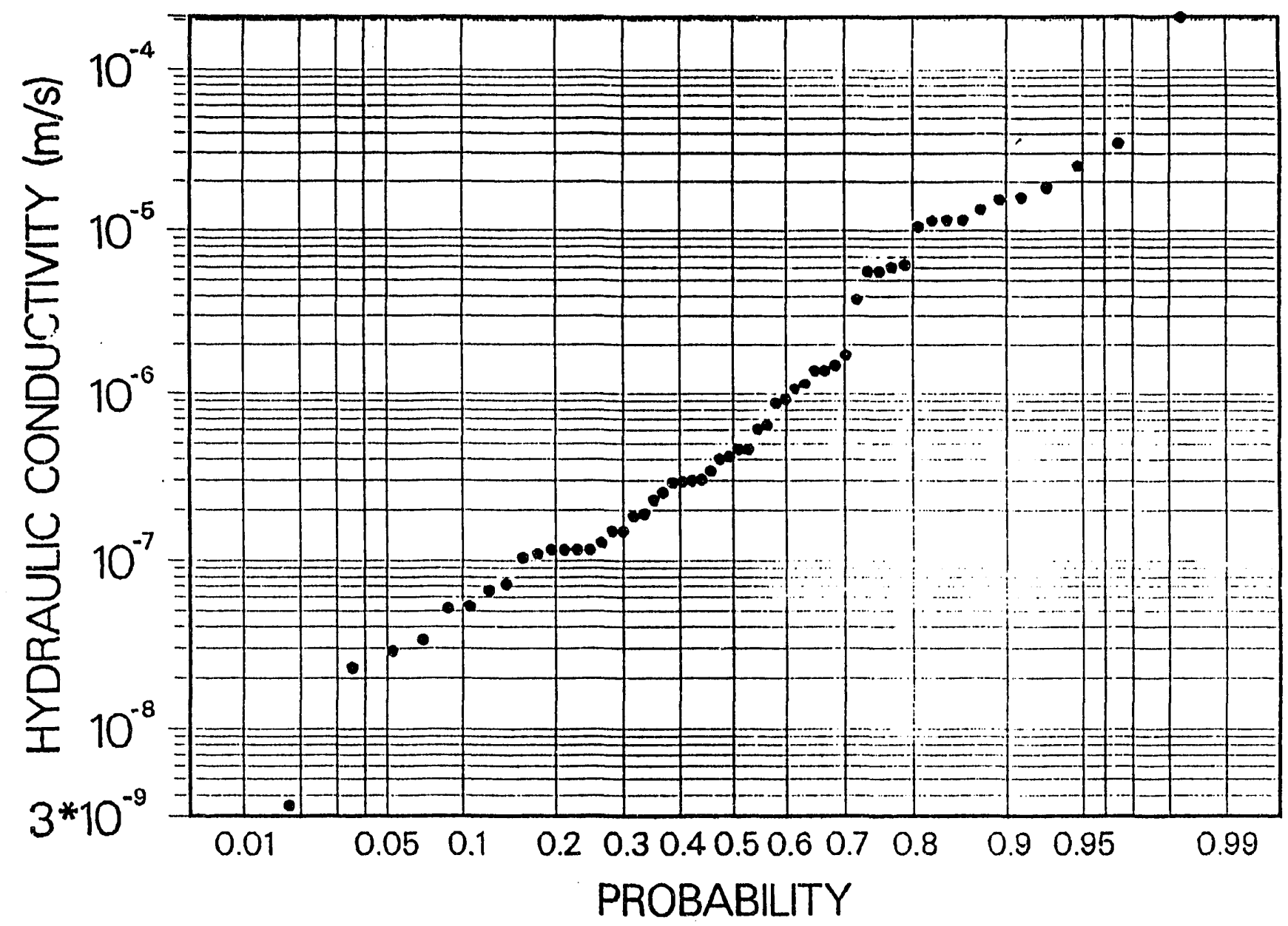

Figure 6. Log-normal probability plot of aquifer test hydraulic conductivity data. 
Examination of the data also shows that much of the rariability observed in the aquifer test data is the result of data from drill hole USW H-1. Base-ten logs of the range of values from each drill hole for which aquifer test data are included in this report show this in Table 9. The anomalously large range of values in USW $\mathrm{H}-1$ appears to be in part due to a zone of high permeability between 652 and $653 \mathrm{~m}$. A negative value for hydraulic conductivity in drill hole USW $\mathrm{H}-1$ suggests that testing difficulties or a poor match between assumptions of the analysis and in situ conditions may also be factors causing large variance in that particular situation. The degree of variability of hydraulic conductivity should be considered in the application of deterministic and stochastic models in transport analysis.

\section{1.c. Discussion}

The hydraulic conductivity data illustrate two phenomena that are of importance to transport analysis and prediction. First, at both laboratory and aquifer test scales, permeability in the Calico Hills nonwelded unit is not homogeneous. The dimensions of an REV, if one exists, are unknown. This indicates a need for rigorous testing of the assumptions that are implicit in deterministic large-scale contaminant transport models and development and testing of alternative theory and methods of predicting transport where needed.

The data also illustrate the dependence of permeability measurement results on the volume of medium tested, known as scale-dependence. The highest geometric mean log hydraulic conductivity at laboratory scales is $4.28 \mathrm{e}-09 \mathrm{~m} / \mathrm{s}$, but geometric mean hydraulic conductivity at aquifer test scales is $7.00 e-07$ $\mathrm{m} / \mathrm{s}$. Testing of larger volumes incorporates more of the variability of the medium into the test volume, including fractures and potential fast flow paths of other types. This is clearly shown by comparison of laboratory data and aquifer test data from the same interval, where aquifer test data usually, but not always, indicate higher permeability than do tests on small samples in the laboratory. Table 10 lists laboratory and aquifer test hydraulic conductivity data obtained from overlapping intervals in drill holes USW $\mathrm{H}-1$ and USW G-4. Scale dependence within the laboratory samples is also suggested and should be investigated.

\subsection{Unsaturated Hydraulic Conductivity}

As a soil desaturates, water is present in only the smaller pores and the cross-sectional area available for flow decreases. This leads to a corresponding decrease in hydraulic conductivity of the soil. The ability of a porous medium to transmit water at a given suction or saturation is known as effective hydraulic 
Table 9. Maximum and minimum hydraulic conductivity values and range of base-ten logarithms of aquifer test hydraulic conductivity data, by drill hole.

\begin{tabular}{lccc}
$\begin{array}{l}\text { Drill } \\
\text { Hole }\end{array}$ & $\begin{array}{c}\text { Maximum } \\
(\mathrm{m} / \mathrm{s})\end{array}$ & $\begin{array}{c}\text { Minimum } \\
(\mathrm{m} / \mathrm{s})\end{array}$ & $\begin{array}{c}\log _{10} \\
(\mathrm{max} / \mathrm{min})\end{array}$ \\
\hline UE-25 b\#1 & $1.15 \mathrm{e}-05$ & $2.89 \mathrm{e}-08$ & 2.60 \\
UE-25 p\#1 & $1.40 \mathrm{e}-06$ & $2.31 \mathrm{e}-08$ & 1.78 \\
USW G-4 & $3.44 \mathrm{e}-07$ & $5.16 \mathrm{e}-08$ & 0.82 \\
USW H-1 & $2.08 \mathrm{e}-04$ & $3.47 \mathrm{e}-09$ & 4.78 \\
USW H-4 & $2.49 \mathrm{e}-05$ & $4.63 \mathrm{e}-07$ & 1.73 \\
USW J-13 & $1.74 \mathrm{e}-06$ & $3.36 \mathrm{e}-08$ & 1.71
\end{tabular}

a Zero and negative values omitted. 
Table 10. Data from laboratory and aquifer testing within selected overlapping intervals.

\begin{tabular}{ll}
$\begin{array}{l}\text { Depth } \\
\text { (m) }\end{array}$ & $\begin{array}{c}\text { Aquifer } \\
\text { Test } \\
\text { USW G-4 }\end{array}$ \\
\hline
\end{tabular}

Laboratory Measurement $(\mathrm{m} / \mathrm{s})$
619.6

640.4

649.8

$616.0-$

655.0

USW G-4

665.2

679.4

700.6

$655.0-$

701.0

USW $\mathrm{H}-1$

640.0

641.0

641.0

616.0-

652.0

USW $\mathrm{H}-1$

764.0

772.0

790.0

791.0

792.0

$758.0-$

792.0

$1.28 e-07$

$4.94 e-10$

4. $36 \mathrm{e}-10$

$3.48 e-10$

$6.80 e-10$ vertical

vertical

horizontal

$3.44 e-07$

4. $15 e-10$

2. $02 e-09$

$6.25 e-09$

$3.08 \mathrm{e}-10$

$1.58 e-08$

$2.23 e-08$ vertical

horizontal

vertical

horizontal

vertical

horizontal 
conductivity, $\mathrm{K}_{\mathrm{eff}}$, or effective permeability. Effective hydraulic conductivity is sometimes expressed as

where

$$
\mathrm{K}_{\mathrm{eff}}=\mathrm{F}_{\mathrm{r}+\mathrm{l}} \times \mathrm{K}_{\mathrm{sat}}
$$

and

$$
\mathrm{K}_{\mathrm{sat}}=\text { saturated hydraulic conductivity }
$$

$$
\mathrm{K}_{\mathrm{rel}}=\mathrm{K}_{\mathrm{eff}} / \mathrm{K}_{\mathrm{sat}}=\text { relative hydraulic conductivity }
$$

Effective hydraulic conductivity is known to be a function of pore-size distribution in the lower suction range and grain surface area in the higher suction range. Determination of effective conductivity relationships requires measurement of fluxes and hydraulic gradients in unsaturated media. This is a difficult and time-consuming task under the best conditions. Field determination of effective hydraulic conductivity in soils is possible, but laboratory measurements are more tractable. Obtaining measurements in unsaturated rock poses major technical challenges, which are currently being addressed. No data from direct determinations of effective permeability in Yucca Mountain tuffs were located.

Theoretical models have been developed to assist in quantifying isotropic effective hydraulic conductivity for modeling purposes (see Mualem, 1986). Many of the models use fluid retention data as a basis for estimating the hydraulic conductivity function in unsaturated media. Widely applied among these are those by Mualem (1976) and Brooks and Corey (1966). Relative hydraulic conductivity curves based on the van Genuchten/Mualem formulation (van Genuchten, 1980) for samples from USW G-4 and USW GU-3 may be found in peters et al. (1984). The van Genuchten/Mualem formulation expresses relative hydraulic conductivity as

$$
K_{\mathrm{rel}}(h)=\frac{\left\{i-(a h)^{n-1}\left[1+(a h)^{n}\right]^{-m}\right\}^{2}}{\left[1+(a h)^{n}\right]^{m / 2}}
$$

where

$$
\begin{aligned}
\mathrm{K}_{\mathrm{rel}}(\mathrm{h}) \quad & \text { relative hydraulic conductivity as a function } \\
& \text { of pressure head } \\
\mathrm{h} & =\text { suction head }(\mathrm{m}) \text { (positive) } \\
\mathrm{a} & =\text { curve fitting parameter }\left(\mathrm{m}^{-1}\right) \\
\mathrm{n} & =\text { curve fitting parameter } \\
\mathrm{m} & =1-1 / \mathrm{n}
\end{aligned}
$$

Sinnock et al. (1986) used the Brooks-Corey function to calculate relative conductivity curves for use in calculational models. The Brooks-Corey erponents, derived by curve fitting to water retention data from $U\lrcorner W$ G-4 and USW GU-3, are listed in Appendix B. Relative hydraulic conductivity is calculated as 


$$
\mathrm{K}_{\mathrm{rel}}(S)=\left[\frac{S-S_{r}}{S_{s}-S_{r}}\right] e
$$

with

$$
\begin{aligned}
& = \\
S_{r}= & \text { residuration } \\
S_{s}= & \text { maximum saturation } \\
\mathbf{e}= & \text { a soil characteristic parameter }=3+2 / b \\
b= & \text { negative slope of the log saturation versus log } \\
& \text { suction curve }
\end{aligned}
$$

It should be emphasized that all of the preceding theoretical hydraulic conductivity models for unsaturated flow were developed for soils and are not tested at the high suction ranges and low unsaturated conductivities found in the calico Hills unit.

Another issue related to saturation and scale dependence of permeability involves the need to establish a relationship between suction and/or moisture content and effective permeability for fractured, unsaturated porous media. As discussed previously, scale dependence of hydraulic conductivity is attributed to the presence of matrix variability and fractures or macropores in the medium. Large pores are the first to desaturate under negative pressures. Laboratory data used to establish moisture characteristic curves and effective permeability curves are derived from small matrix samples. The data and the hydraulic conductivity models discussed in the preceding paragraph do not incorporate the effects of fractures on permeability at high saturations. Since larger pores desaturate first, permeability at low saturations is not thought to be affected by fractures, although it is possible that fractures may act as barriers to unsaturated flow. Effective permeability curves for fractured media, or composite curves, have been proposed (Wang and Narasimhan, 1986; Klavetter and Peters, 1986; Peters and Klavetter, 1988; Dudley et al., 1988), but no comparison with data has been reported to date. It is not established if, and under what conditions, fracture flow occurs in the Calico Hills nonwelded unit.

A further concern related to effective hydraulic conductivity is the likelihood that anisotropy of unsaturated tuff becomes more pronounced under increasingly unsaturated conditions (Yeh and Gelhar, 1983; Yeh et al., 1985). An increase in the ratio of horizontal to vertical hydraulic conductivity with increased tension has the effect of magnifying the importance of lateral flow above what would be anticipated on the basis of vertical and horizontal saturated permeability measurements. This phenomenon has been observed repeatedly in the field (see discussion in Gelhar et al., 1985) and is a potentially important issue to transport modeling. studies have 
shown that local effective hydraulic conductivity functions are only minimally hysteretic (Luckner et al., 1989), but that under certain circumstances (i.e., stratification) heterogeneity of the medium can cause strongly anisotropic behavior under wetting conditions but not drying (Mantoglou and Gelhar, 1987).

\subsection{Fluid Potentials and Saturations}

Laboratory measurements of fluid potential as a function of saturation for samples from USW G-4, USW GU-3 and USW G-1 were presented by Peters et al. (1984) and Klavetter and Peters (1987). Accuracy of the thermocouple psychrometer data is reported to be within 10 meters ( 1 bar) (Peters et al., 1984). statistical fitting of the van Genuchten curves to the data (Rutherford et al., 1992) resulted in the saturation curve fitting parameters listed in Appendix B. Samples from zeolitized, vitric and devitrified nonwelded and partially welded tuffs and bedded tuffs are included. The van Genuchten formulation relates saturation and suction according to

$$
S=\left(S_{s}-S_{r}\right)\left[\frac{1}{1+(a h)^{n}}\right]^{m}+S_{r}
$$

with

$$
\begin{aligned}
& \mathrm{h}=\text { suction head ( } \mathrm{m}) \text { (positive) } \\
& \mathrm{s}=\text { saturation as a function of suction head } \\
& \mathrm{S}_{\mathrm{s}}=\text { maximum saturation } \\
& \mathrm{S}_{\mathrm{r}}=\text { residual saturation } \\
& \mathrm{a}=\text { curve fit parameter }\left(\mathrm{m}^{-1}\right) \\
& \mathrm{n}=\text { curve fit parameter } \\
& \mathrm{m}=1-1 / \mathrm{n}
\end{aligned}
$$

Variability within the unit is evident in the curves. Data are obtained by drying the samples in steps and measuring suction at each step. The curves are drying curves. Wetting data are not available, and the importance of hysteresis to analysis and prediction of flow in the tuffs is not established at this time. As long as steady state conditions prevail, changes in saturation do not occur and hysteresis is not an issue. Recent work has shown that significant prediction error may result when hysteresis is neglected (Dane and Wierenga, 1975; Hoa et al., 1977; Kaluarachchi and Parker, 1987). Luckner et al. (1989) discuss and present models for direction-dependent (wetting or drying) saturation-suction relationships.

In the absence of thermal and chemical gradients, fluid potentials in unsaturated media are a function of pressure (matric suction) and elevation. In situ measurements of fluid potentials in the calico Hills nonwelded unit have not been obtained. However, natural bulk density, dry bulk density and 
grain density data from cores allow determination of moisture content, porosity and saturation (Hillel, 1980). Saturation data may then be used in conjunction with moisture characteristic curves obtained in the laboratory to estimate a distribution of in situ fluid potentials. Variations in saturation reflect heterogeneities in the moisture characteristic properties of the medium together with spatial variation of fluid potential. As shown in Table 4, saturation data have been included in Appendix $B$ for drill holes UE-25 a\#1, UE-25 b\#1, G-1, GU-3, G-4, $\mathrm{H}-1$ and J-13. Examination of the data shows that some error is incorporated into the analysis because a few of the calculated saturations exceed one and because saturation values from core extracted below the water table are lower than unity. Some of the error may be due to drying of core during handling (Anderson, 1984). Sources of error in density and porosity measurements are discussed in Schwartz (1990).

Since the data come from different samples it is not possible to combine saturation values directly with moisture characteristic curves to infer in situ fluid potentials. However, it is clear that saturations are generally high in the Calico Hills nonwelded unit. Table 11 summarizes saturation statistics from vitric, zeolitized and devitrified tuff samples obtained above the water table. Mean saturation in vitric tuffs is $80 \%$, in devitrified tuffs is $87 \%$, and in zeolitic tuffs is $92 \%$.

Using available data it is not possible to gain insight into the question of whether or not matric suctions are relatively uniform throughout the unit, as they would be under the unit gradient conditions postulated by Montazer and Wilson (1984), Sinnock et al. (1986), Peters and Klavetter (1988) and others. A statistical study of saturation distribution resulting from unit gradient conditions in the Calico Hills based on the fluid retention curves in Appendix $B$ would be interesting and may help to shed light on the validity of that assumption. Measurements of fluid potentials (matric suctions) in cuttings from the Topopah spring member of the Paintbrush Tuff in drill hole UsW UZ-1 show spatial variations in fluid suction of over an order of magnitude (from -20 to -400 bars) within a vertical distance of 30 meters (Montazer et al., 1988). Equilibrium conditions would dictate approximately a 3-bar difference in fluid suction with a $30 \mathrm{~m}$ change in elevation, and unit gradient conditions would dictate no difference in fluid suction with a change in elevation.

\subsection{Total and Kinematic Porosity}

Total porosity is the ratio of volume occupied by voids to total volume of a sample. Kinematic porosity, or effective porosity, is the ratio of volume of pores that actually 
Table 11. Sample statistics of saturation data for vitric, devicrified and zeolitic tuffs in the unsaturated zone.

\section{vitric}

No. Samples

Minimum

Maximum

Range

Arith. Mean Median

Variance

Skewness

c.V."
14

0.65

0.97

0.32

0.80

0.81

0.009

0.25

0.12
Devitrified

30

0.33

1.02

0.69

0.87

0.90

0.018

$-2.26$

0.15

\section{Zeolitic}

79

0.47

1.31

0.84

0.92

0.94

0.013

$-1.49$

0.12

a Coeficient of variation. 
participate in flow to total volume of saturated medium. This is the porosity that determines the velocity at which a solute moves in porous flow. Total porosity can be considerably greater than kinematic porosity, the difference being determined by the number of dead-end and nonconnected pores and the pore-size distribution. Water molecules in porous media are bound to the solid by molecular forces or free to move in response to fluid gradients. Fine-grained media with small pores and large grain surface areas have a larger percentage of total water adhered to grain surfaces, resulting in a lower kinematic porosity than for larger-grained media. Although kinematic porosity is a function of the magnitude of the hydraulic gradient, it is generally taken to bf a constant, usually determined by tracer tests. The reader is referred to de Marsily (1986) for more on this subject.

Total porosity can be measured directly by fluid displacement or can be determined indirectly from measurements of dry bulk and grain density. Table 12 summarizes sample statistics of total porosity data for vitric, devitrified and zeolitic tuffs. Mean total porosity in vitric tuffs is $37 \%$, in devitrified tuffs is $27 \%$ and in zeolitic tuffs is $29 \%$. The correlation between porosity and log hydraulic conductivity was found to be 0.265 . As was the case with saturation, total porosity shows less variability than does hydraulic conductivity in the unit. Total porosity is the proper parameter for calculation of changes in storage, or capacitance, in unsaturated flow models.

No values of kinematic porosity for the calico Hills nonwelded unit have been published. Montazer and Wilson (1984) cite a possible value of 0.016 for effective porosity of the vitric facies matrix under saturated conditions, based on poresize distribution data. The same authors estimated effective pozosity of the unit under unsaturated conditions to be around 0.23 , with fractures contributing little or nothing under ambient unsaturated conditions.

\subsection{Pore-Size Distribution}

Mercury intrusion pore-size distribution data from USW G-4, USW GU-3 and USW G-1 samples are included on microfiche in Klavetter and Peters (1987), who evaluated the use of these data for indirect determination of hydrologic properties including saturated hydraulic conductivity and moisture characteristic curves. The previous authors concluded that the approach was probably not sufficiently accurate for many performanceassessment applications since mercury intrusion data produced, at times, physically unrealistic saturation curves. 
Table 12. Sample statistics of total porosity data for vitric, devitrified and zeolitic tuffs.

\section{Vitric}

No. Samples

Minimum

Maximum

Range

Arith. Mean

Median

Variance

Skewness

C.V.a

- Coefficient of variation.

\section{Devitrified}

27

0.169

0.48

0.311

0.37

0.39

0.008

$-0.939$

0.24
49

0.131

0.397

0.266

0.27

0.27

0.004

0.141

0.22

\section{Zeolitic}

129

0.097

0.47

0.373

0.29

0.30

0.005

$-0.378$

0.23 
Except for the Montazer and Wilson reference above, no information related to application of pore-size distribution data to determination of kinematic porosity was located. However, these data could provide a means of estimating values for model input until additional data becomes available. Median pore-size data for USW G-1, USW GU-3 and USW G-4 are summarized in Appendix B. It is clear that median pore sizes are extremely small. This is significant because water molecules within 0.1 micron of a particle surface are subjected to adhesive forces of up to several $10^{12} \mathrm{~Pa}$, resulting in increased viscosity and density (de Marsily, 1986). Water molecules within about 0.5 micron of particle surfaces are similarly immobilized and do not move freely. The exact outer limit depends on the nature of the substrate. The result is a reduction in the volume of water that is able to circulate. This reduced area/volume available for flow should be taken into account when calculating velocity in transport models.

\subsection{DISPERSION}

Hydrodynamic dispersion refers to a nonsteady, irreversible spreading of solute beyond the region it is expected to occupy that is observed during flow through a porous medium (Bear, 1972). Characterization of dispersion in saturated and unsaturated Calico Hills nonwelded unit tuffs is required for predictive transport calculations.

Modeling of solute transport with the advection-dispersion equation incorporates a coefficient, analogous to the diffusion coefficient in Fick's Law, to account for dispersion. In the direction parallel to flow, this dispersion coefficient is expressed as

$$
D_{L}=\phi d+\alpha_{L} U
$$

where

$$
\begin{aligned}
& D_{L}=\text { longitudinal dispersion coefficient } \\
& \phi=\text { total porosity } \\
& d=\text { molecular diffusion coefficient in porous media } \\
& \alpha_{L}=\text { longitudinal dispersivity } \\
& \mathrm{U}=\text { modulus of mean pore velocity }
\end{aligned}
$$

Dispersivity is typically determined from tracer test

breakthrough data. No values of dispersivity for tuffs from the Calico Hilis nonwelded unit have been reported. Rundberg et al. (1989) reported results of tracer tests in saturated, intact, densely welded Topopah spring member tuff columns that could not be fit to the classical advection-dispersion equation. Elution 
curves from the intact tuff experiments appeared to exhibit timedependent dispersion at the laboratory scale, but no values for the dispersion coefficients were reported. Dispersivities for tritiated water and pertechnetate in intact tuff were reported to be much greater than dispersivities observed in crushed tuff columns, and dispersivities for sorbing tracers were reported to be significantly greater than dispersivities for tritiated water in the same columns. It was concluded that statistical characterization of the spatial distribution of sorbing minerals and hydraulic conductivity were required for predictive efforts, and that the effects of time-dependent dispersion would be magnified at field and repository scales.

Gelhar et al. (1985) summarized field-scale dispersivities reported in the literature for unsaturated flow in soils. The data are few, but do show an increase of longitudinal dispersivity with scale. Values range from $0.0011 \mathrm{~m}$ to $0.7 \mathrm{~m}$. This phenomenon is also observed for transport in saturated media (see Neuman, 1990).

Recent stochastic theories relate dispersive properties of porous and fractured media to the nonuniform velocity field of flow in heterogeneous media. These approaches are based on stochastic analyses of the hydraulic conductivity field. Reductions in uncertainty of predictions are achieved by conditioning on values of hydraulic conductivity, water potential and solute concentration at known points and by the incorporation of inverse methods (Graham and McLaughlin, 1989). Due to the recent development of the theory, the complexity of the problem, the lack of data and the nonlinearity of processes in unsaturated media, extension to the unsaturated zone has yet to be attempted.

\subsection{Storage Coefficients}

\section{7.a. Specific Storage}

While no published values for specific storage in the calico Hills nonwelded unit have been located by this author, it is possible to estimate a value based on the following relationship (Freeze and Cherry, 1979)

$$
S_{s}=\rho g\left(C_{r}+\phi C_{f}\right)
$$

where

$$
\begin{aligned}
& \mathrm{S}_{\mathrm{s}}=\text { specific storage }[1 / \mathrm{m}] \\
& \rho=\text { fluid density }\left[\mathrm{kg} / \mathrm{m}^{3}\right] \\
& \mathrm{g}=\text { acceleration of gravity }\left[\mathrm{m} / \mathrm{s}^{2}\right] \\
& \mathrm{c}_{\mathrm{r}}=\text { rock compressibility }[1 / \mathrm{Pa}]
\end{aligned}
$$




$$
\begin{aligned}
& \phi=\text { total porosity } \\
& \mathbf{c}_{\mathrm{f}}=\text { fluid compressibility }[1 / \mathrm{Pa}]
\end{aligned}
$$

Using the values summarized in Table 13 and Equation (7), a specific storage of $5.50 \times 10^{-6} \mathrm{~m}^{-1}$ was calculated for vitric tuff and $3.85 \times 10^{-6} \mathrm{~m}^{-1}$ was calculated for zeolitic tuff.

\section{7.b. Capacitance}

Fluid storage in unsaturated media is expressed as capacitance, which is a function of the relationship between suction and water content, water compressibility, bulk rock compressibility and fracture compressibility. Models of capacitance in porous media are discussed by Luckner et al. (1989), Wang and Narasimhan (1986) and Klavetter and Peters (1986). Peters and Klavetter (1988) discuss capacitance models in a fracture-matrix continuum.

\section{THERMOMECHANICAL PROPERTIES}

Thermomechanical property data are presented in Nimick (1990), Nimick et al. (1984; 1987, zeolitized bedded tuffs in lower Topopah Spring), Ortiz et al. (1985), Lappin and Nimick (1985), Ogard et al. (1983) and Price and Jones (1982). Grain and bulk density data can be found in Schwartz (1990) and in U.S. Geological Survey reports from individual drill holes.

Maximum vertical stress at the water table was estimated by Peters et al. (1984) to be on the order of 130 bars.

Table 13. Property values used to calculate specific storage.

Fluid density.............1000. $\mathrm{kg} / \mathrm{m}^{3}$

Acceleration of gravity.......... $81 \mathrm{~m} / \mathrm{s}^{2}$

Rock compressibility $\ldots \ldots \ldots \ldots . . .98 \times 10^{-10} \mathrm{~Pa}^{-1}$ vitric

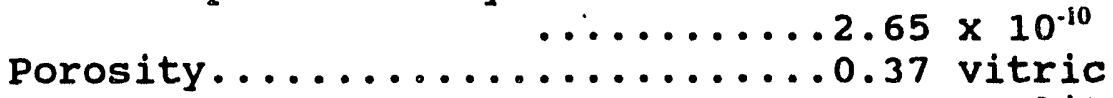

$a^{-1}$ zeolitic

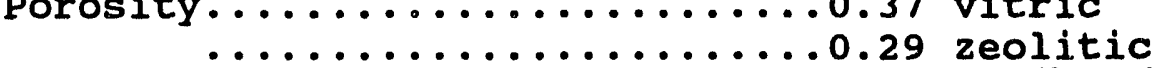

Fluid compressibility........4.4 × $10^{-10} \mathrm{~Pa}^{-1}$

a Rock compressibility Nimick et al. (1984). 


\section{CONCLUSIONS AND RECOMMENDATIONS}

This report summarizes hydrologic data from the Calico Hills nonwelded unit, an informal hydrogeologic unit. Hydraulic conductivity data are found to show significant heterogeneity at both laboratory and aquifer test scales. At both scales, reported hydraulic conductivity values range over several orders of magnitude. This is a strong indication that incorporating variability in field and regional scale flow and transport predictions is important. Even the results of long-term fieldscale tracer tests will be insufficient to provide adequate information for determining dispersive properties of the calico Hills nonwelded unit on a scale of kilometers. Theoretical work focused on the characterization of transport at all scales is needed. Development of a plan for collecting data needed for support of theoretical work as well as for use in existing flow and transport models should be a priority.

Analysis suggests that it is necessary to include devitrified tuffs as distinct from zeolitized tuffs in flow and transport models. Other specific issues and needs identified are summarized below.

1. Physical characteristics and measurements of hydrologic parameters show that the Calico Hills nonwelded

hydrogeologic unit does not conform to the concept of a homogeneous porous medium in the classical sense at the scale of currently available measurements. The effects of heterogeneities in the Calico Hills on contaminant transport processes and on proper representation of those processes in models are not well understood. Specific areas that require additional research include

a. Determination of the nature of fracture flow. The conditions under which fracture flow occurs in the Calico Hills nonwelded unit have fundamental implications for the direction of work in modeling, sorption studies and mineralogical characterization.

b. The question of scale is complicated by the difficulty of obtaining measurements on larger samples or in situ. Relationships between the scale of measurements and the scale of modeling must be determined, particularly for permeability and dispersivity. As these relationships may well be saturation dependent, it is not possible to identify scales most in need of characterization a priori. 
c. Investigate possible directional or preferential flow effects due to capillary barrier and/or saturation-dependent anisotropy induced by interlayered bedded tuffs and devitrified tuffs in vitric and zeolitic facies.

d. Evaluate the existence and volume of an REV for matrix and fracture-matrix hydraulic conductivity measurements, for both saturated and unsaturated conditions.

e. Evaluate the effects of variations in sample size, handling and test methods on measured permeabilities as a means of assessing currently available data from Yucca Mountain.

f. Evaluate whether partial welding in tuffs has significant effects on hydrologic processes relative to those in nonwelded tuff.

2. Effective permeability relationships for both liquids and gases in unsaturated vitric, devitrified and zeolitized partially welded and nonwelded tuff are needed.

3. A basis for determining effective cross-sectional area of flow is required for velocity calculations. Kinematic porosity of tuffs from the Calico Hills nonwelded unit has not been characterized. It may be possible to correlate kinematic porosity with pore-size distribution in some cases.

4. Dispersion in saturated and unsaturated vitric, devitrified and zeolitic partially welded and nonwelded tuffs at various scales must be characterized. A plan for systematic sampling of hydraulic conductivity and unsaturated matrix properties is needed to establish a data base for both deterministic and stochastic transport modeling. Traditional and more recent approaches to characterizing dispersion must be tested against field data as a means of testing theory and application to the medium of interest.

5. Cross correlation between hydraulic conductivity and mineralogy should be further investi jated. The potential effects of a positive correlation between large hydraulic conductivity and nonsorptive mineralogy have implications for radionuclide transport, as does the reverse situation. Any such correlations will probably be saturation dependent.

6. Models require in situ saturation and suction distribution data for setting initial and boundary conditions in flow and transport models. 
7. Techniques for assigning hydraulic conductivities to grid blocks at larger than measurement scales are needed.

8. Research related to quantifying net percolation flux and spatial distribution of flow should be continued.

9. Improved methods for obtaining measurements of all kinds in the unsaturated zone are needed.

Hydrologic and geochemical processes in the unsaturated zone are extremely complex. Interest in unsaturated transport is relatively recent, and understanding of those processes is at an early stage of development. Continued work aimed at characterizing processes important to contaminant transport in unsaturated tuffs, determining parameters quantifying those processes and field testing is needed.

Acknowledgments

Preparation of this report was funded by the Los Alamos National Laboratory Yucca Mountain site Characterization Project under Los Alamos National Laboratory contract \#9-XT8-1281Q-1 with Science and Engineering Associates, Inc., 1570 Pacheco Street, Santa Fe, New Mexico 87501. 


\section{REFERENCES}

Anderson, L.A., "Water Permeability and Related Rock Properties Measured on Core Samples From the Yucca Mountain USW GU-3/G-3 and USW G-4 Boreholes, Nevada Test Site, Nevada," U.S. Geological Survey Open-File Report USGS-OFR-92-201 (1992).

Anderson, L.A., "Rock Property Analysis of Core Samples From the Yucca Mountain UE-25 A\#1 Borehole, Nevada Test Site, Nevada," U.S. Geological Survey Open-File Report USGS-OFR-81-1338 (1981), YMP Accession No. HQS.880517.1897

Anderson, L.A.; "Rock Property Measurements On Large-Volume Core Samples From Yucca Mountain USW GU-3/G-3 and USW G-4 Boreholes, Nevada Test Site, Nevada," U.S. Geological Survey Open-File Report 84-552 (1984), YMP Accession No. HQS.880517.1039

Bear, J., Dynamics of Fluids in Porous Media (American Elsevier Publishing Co., Inc., New York, 1972), YMP Accession No. NNA. 890713.0163

Bentley, C.B., J.H. Robison and R.W. Spengler, "Geohydrologic Data for Test Well USW H-5, Yucca Mountain Area, Nye County, Nevada," U.S. Geological Survey Open-File Report 83-853 (1983), YMP Accession No. HQS.880517.1069

Bish, D.L. and S.J. Chipera, "Revised Mineralogic Summary of Yucca Mountain, Nevada," Los Alamos National Laboratory report LA-11497-MS (1989), YMP Accession No. NNA.891005.0072

Bish, D.L., D.T. Vaniman, R.S. Rundberg, K. Wolfsberg, W.R. Daniels and D.E. Broxton, "Natural Sorptive Barriers in Yucca Mountain, Nevada, for Long-Term Isolation of High-Level Waste," in Radioactive Waste Management 3 (International Atomic Energy Agency, 1984b) 415-432, YMP Accession No. NNA.890602.0025

Brooks, R.H. and A.T. Corey, "Properties of Porous Media Affecting Fluid Flow," Journal of the Irrigation and Drainage Division Am. SOC. Civ. Eng. 92, IR2, 61-88 (1966), YMP Accession No. NNA. 870407.0356

Broxton, D.E., F.M. Byers, Jr. and R.G. Warren, "Petrography and Phenocryst Chemistry of Volcanic Units at Yucca Mountain, Nevada: A Comparison of Outcrop and Drill Hole Samples," Los Alamos National Laboratory report LA-11503-MS (1989), YMP Accession No. NNA. 890224.0089

Bryant, E.A. and D.T. Vaniman, "Research and Development Related to the Nevada Nuclear Waste Sto:age Investigations, July 1 September 30, 1983," Los Alamos National Laboratory report LA10006-PR (1984), YMP Accession No. HQS.880517.1962 
Carr, M.D., S.J. Waddell, G.S. Vick, J.M. Stock, S.A. Monsen, A.G. Harris, B.W. Cork, F.M. Byers, Jr., "Geology of Drill Hole UE-25 P\#1: A Test Hole Into Pre-Tertiary Rocks Near Yucca Mountain, Southern Nevada," U.S. Geological Survey open-File Report 86-175 (1986), YMP Accession No. HQS.880517.2633

Craig, R.W. and J.H. Robison, "Geohydrology of Rocks Penetrated by Test Well UE-25 P\#1, Yucca Mountain Area, Nye County, Nevada," U.S. Geological Survey Water-Resources Investigations Report USGS-WRI-84-4248 (1984), YMP Accession No. NNA. 870519.0106

Craig, R.W., R.L. Reed and R.W. Spengler, "Geohydrologic Data for Test Well USW H-6, Yucca Mountain Area, Nye County, Nevada," U.S. Geological Survey open-File Report 83-856 (1983), YMP Accession No. NNA.870406.0058

Dagan, G., Flow and Transport in Porous Formations (SpringerVerlag, New York, 1989), YMP Accession No. Readily Available

Dagan, G., "Theory of Solute Transport by Ground-Water," Annual Reviews of Fluid Mechanics 19, 183-215 (1987), YMP Accession No. NNA. 920320.0015

Dagan, G., "Statistical Theory of Groundwater Flow and Transport: Pore to Laboratory, Laboratory to Formation, and Formation to Regional Scale," Water Resources Research 22, 9, $120 S$ - 134S (1986), YMP Accession No. NNA.891107.0098

Dane, J.H. and P.J. Wierenga, "Effect of Hysteresis on the Prediction of Infiltration, Redistribution and Drainage of Water in a Layered Soil Under Transient Flow Conditions," J. Hydrology 25, 229-242 (1975), YMP Accession No. NNA.910506.0134

de Marsily, G., Quantitative Hydrogeology (Academic Press, Inc., Orlando, Florida, 1986), YMP Accession No. NNA.910207.0116

Dudley, A.L., R.R. Peters, J.H. Gauthier, M.L. Wilson, M.S. Tierney and E.A. Klavetter, "Total System Performance Assessment Code (TOSPAC) Volume 1: Physical and Mathematical Bases," Sandia National Laboratory report SAND 85-0002 (1988), YMP Accession No. NNA.881202.0211

Freeze, R.A., "A Stochastic-Conceptual Analysis of OneDimensional Groundwater Flow in a Non-Uniform Homogeneous Media," Water Resources Research 11, 5, 725-741 (1975), YMP Accession No. NNA. 890713.0237

Freeze, R.A. and J.A. Cherry, Groundwater (Prentice-Hall, Inc., Englewood Cliffs, New Jersey, 1979), YMP Accession No. NNA. 870406.0444 
Gelhar, L.W. and C.L. Axness, "Three-Dimensional stochastic Analysis of Macrodispersion in Aquifers," Water Resources Research 19, 1, 161 - 180 (1983), YMP Accession No. NNA. 920320.0016

Gelhar, L.W., A. Mantoglou, C. Welty and K.R. Rehfeldt, "A Review of Field-Scale Physical Solute Transport Processes in Saturated and Unsaturated Porous Media," Electric Power Research Institute report EA-4190 (1985), YMP Accession No. NNA. 900123.0068

Glass, R.J., T.S. Steenhuis and J.-Y. Parlange, "Wetting Front Instability as a Rapid and Far-Reaching Hydrologic Process in the Vadose Zone," Journal of Contaminant Hydrology 3, 207-226

(1988), YMP Accession No. NNA.920320.0017

Graham, w. and D. McLaughlin, "stochastic Analysis of Nonstationary Subsurface Solute Transport, 2. Conditional Moments," Water Resources Research 25, 11, 2331 - 2355 (1989), YMP Accession No. NNA.920320.0018

Hillel, D., Fundamentals of Soil Physics (Academic Press, Inc., Orlando, Florida, 1980), YMP Accession No. HQS.880517.1776

Hoa, H.T., R. Gaudu and C. Thirriot, "Infiucrice of Hysteresis Effect on Transient Flows in Saturated-Unsaturated Porous Media," Water Resources Research 13, 6, 992-996 (1977), YMP Accession No. NNA. 910506.0135

Kaluarachchi, J.J. and J.C. Parker, "Effects of Hysteresis With Air Entrapment on Water Flow in the Unsaturated Zone," Water Resources Research 23, 10, 1967-1976 (1987), YMP Accession No. NNA. 920320.0019

Klavetter, E.A. and R.R. Peters, "An Evaluation of the Use of Mercury Porisimetry in Calculating Hydrologic Properties of Tuffs From Yucca Mountain, Nevada," Sandia National Laboratories report SAND 86-0286 (1987), YMP Accession No. HQS.880517.3119

Klavetter, E.A. and R.R. Peters, "Estimation of Hydrologic Properties of an Unsaturated, Fractured Rock Mass," Sandia National Laboratories report SAND 84-2642 (1986), YMP Accession No. NNA. 870317.0738

Lahoud, R.G., D.H. Lobmeyer and M.S. Whitfield, "Geohydrology of Volcanic Tuff Penetrated by Test Well UE-25 B\#1, Yucca Mountain, Nye County, Nevada," U.S. Geological Survey Water Resource Investigation Report 84-4253 (1984), YMP Accession No. NNA. 890922.0286 
Langkopf, B.S. and P.R. Knirk, "Rock-Mass Classification of Candidate Repository Units at Yucca Mountain, Nye County, Nevada," Sandia National Laboratories report SAND 82-2034 (1986), YMV Accession No. HQS.880517.1662

Lappin, A.R. and F.B. Nimick, "Bulk and Thermal Properties of the Functional Tuffaceous Beds in Holes USW G-1, UE-25A\#1, and USW G-2, Yucca Mountain, Nevada," Sandia National. Laboratories report SAND 82-1434 (1985), YMP Accession No. NNA.890315.0020

Lappin, A.R., R.G. VanBuskirk, D.O. Enniss, S.W. Butters, F.M. Prater, C.B. Muller and J.L. Bergosh, "Thermal Conductivity, Bulk Properties, and Thermal stratigraphy of silicic Tuffs From the Upper Portion of Hole USW G-1, Yucca Mountain, Nye County, Nevada," Sandia National Laboratories report SAND 81-1873 (1982), YMP Accession No. HQS.880517.1669

Lobmeyer, D.H., M.S. Whitfield, Jr., R.G. Lahoud and L. Bruckheimer, "Geohydrologic Data for Test Well UE-25 B\#1H, Nevada Test Site, Nye County, Nevada," U.S. Geological Survey open-File Report 83-855 (1983), YMP Accession No. NNA.890922.0285

Luckner, L., M.Th. van Genuchten and D.R. Nielsen, "A Consistent Set of Parametric Models for the Two-Phase Flow of Immiscible Fluids in the Subsurface," Water Resources Research 25, 10, 2187-2193 (1989), YMP Accession No. NNA.920320.0020

Maldonado, F. and S.L. Koether, "Stratigraphy, structure, and Some Petrographic Features of Tertiary Volcanic Rocks at the Usw G-2 Drill Hole, Yucca Mountain, Nye County, Nevada," U.S. Geological Survey Open-File Report 83-732 (1983), YMP Accession No. NNA. 870506.0143

Mantoglou, A. and L.W. Gelhar, "Effective Hydraulic Conductivities of Transient Unsaturated Flow in Stratified Soils," Water Resources Research 23, 1, 57-67 (1987), YMP Accession No. NNA.891109.0138

Montazer, P. and W.E. Wilson, "Conceptual Hydrologic Model of Flow in the Unsaturated Zone, Yucca Mountain, Nevada," U.S. Geological Survey Water-Resources Investigations Report 84-4345 (1984), YMP Accession No. NNA.890327.0051

Montazer, P., E.P. Weeks, F. Thamir, D. Hammermeister, S.N. Yard and P.B. Hofrichter, "Monitoring the Vadose Zone in Fractured Tuff," Ground Water Monitoring Review 8, 2, 72-88 (1988), YMP Accession No. NNA.900123.0073 
Mualem, Y., "Hydraulic Conductivity of Unsaturated Soils: Prediction and Formulas," in Methods of Soil Analysis, Part I. Physical and Mineralogical Methods Agron. Monogr. 9, 2nd ed., (American Society of Agronomy-Soil Science Society of America, Madison, Wisconsin 1986) 799-823, YMP Accession No. NNA. 920501.0122

Mualem, Y., "A New Model for Predicting the Hydraulic Conductivity of Unsaturated Porous Media," Water Resources Research 12, 3, 513-522 (1976), YMP Accession No. NNA.890522.0250

Muller, D.C. and J.E. Kibler, "Preliminary Analysis of Geophysical Logs From the WT Series of Drill Holes, Yucca Mountain, Nye County, Nevada," U.S. Geologic Survey open-File Report 86-46 (1985), YMP Accession No. HQS.880517.1354

Neuman, S.P., "Universal Scaling of Hydraulic Conductivities and Dispersivities in Geologic Media," Water Resources Research 26, 8, 1749-1758 (1990), YMP Accession No. NNA.920320.0021

Neuman, S.P., "Stochastic Continuum Representation of Fractured Rock Permeability as an Alternative to the REV and Fracture Network Concepts," Proc. 28th U.S. Symposium on Rock Mechanics 533-561 (Tucson, Arizona, 1987), YMP Accession No. NNA. 920320.0022

Neuman, S.P., C.L. Winter and C.M. Newman, "Stochastic Theory of Field-Scale Fickian Dispersion in Anisotropic Porous Media," Water Resources Research 23, 3, 453-466 (1987), YMP Accession No. NNA. 920320.0023

Neuman, S.P. and J.S. Depner, "Use of Variable-Scale Pressure Test Data to Estimate the Log Hydraulic Conductivity Covariance and Dispersivity of Fractured Granites Near oracle, Arizona," Journal of Hydrology 102,475-501 (1988), YMP Accession No. NNA. 920501.0123

Nimick, F.B., "The Thermal Conductivity of Seven Thermal/Mechanical Units at Yucca Mountain, Nevada," Sandia National Laboratories report SAND 88-1387 (1990), YMP Accession No. NNA. 891213.0201

Nimick, F.B., R.G. van Buskirk and A.F. McFarland, "Uniaxial and Triaxial Compression Test Series on the Topopah Spring Member From USW G-2, Yucca Mountain, Nevada," Sandia National Laboratories report SAND 85-0703 (1987), YMP Accession No. NNA. 891019.0289 
Nimick, F.B., S.J. Bauer and J.R. Tillerman, "Recommended Matrix ard Rock-Matrix Bulk, Mechanical and Thermal Properties for Thermomechanical Stratigraphy of Yucca Mountain," Sandia National Laboratories Keystone Document 6310-85-1 (1984), YMP Accession No. HQS.880517.2323

Ogard, A.E., K. Wolfsberg and D.T. Vaniman, "Research and Development Related to the Nevada Nuclear Waste Storage Investigations. April 1 - June 30, 1983," Los Alamos National Laboratory report LA-9846-PR (1983), YMP Accession No. HQS. 880517.2034

Ortiz, T.S., R.L. Williams, F.B. Nimick, B.C. Whittet and D.L. South, "A Three-Dimensional Model of Thermal/Mechanical and Hydrologic stratigraphy at Yucca Mountain, Southern Nevada," Sandia National Laboratories report SAND 84-1076 (1985), YMP Accession NO. HQS.880517.1691

Peters, R.R. and E.A. Klavetter, "A Continuum Model for Water Movement in an Unsaturated Fractured Rock Mass," Water Resources Research 24, 3,416-430 (1988), YMP Accession No. NNA.890523.0139

Peters, R.R., E.A. Klavetter, I.J. Hall, S.C. Blair, P.R. Heller and G.W. Gee, "Fracture and Matrix Hyorologic Characteristics of Tuffaceous Materials From Yucca Mountain, Nye County, Nevada," Sandia National Laboratories report SAND 84-1471 (1984), YMP Accession No. NNA.900810.0674

Price, R.H. and A.K. Jones, "Uniaxial and Triaxial Compression Test Series on Calico Hills Tuff," Sandia National Laboratories report SAND 82-1314 (1982), YMP Accession No. NNA.900810.0480

Rundberg, R.S., A.J. Mitchell, M.A. Ott, J.L. Thompson and I.R. Triay, "Laboratory studies of Radionuclide Migration in Tuff," in Proceedings of the Topical Meeting on Nuclear Waste Isolation in the Unsaturated Zone Focus '89, 248-255 (1989), YMP Accession No. NNA. 901025.0006

Rush, F.E., W. Thordarson and L. Bruckheimer, "Geohydrologic and Drill-Hole Data for Test Well USW H-1, Adjacent to Nevada Test Site, Nye County, Nevada," U.S. Geological survey Open-File Report 83-141 (1983), YMP Accession No. HQS.880517.1835

Rush, F.E., W. Thordarson and D.G. Pyles, "Results of Hydraulic Tests in Well USW $\mathrm{H}-1$, Nevada Test Site, Nye County, Nevada," U.S. Geological Survey Water Resources Investigation Report 844032 (1984), YMP Accession No. HQS.880517.1836

Rutherford, B.M., I.J. Hall, R.G. Easterling, R.R. Peters and E.A. Klavetter, "Statistical Analysis of Hydrologic Data for Yucca Mountain," Sandia National Laboratories report SAND 872380 (1992), YMP Accession No. NNA.910822.0001 
Schwartz, B.M., "SNL Yucca Mountain Project Data Report: Density and Porosity Data for Tuffs From the Unsaturated zone at Yucca Mountain, Nevada," Sandia National Laboratories report SAND 88-0811 (1990), YMP Accession No. NNA.900108.0028

Scott, R.B. and M. Castellanos, "Stratigraphic and structural Relations of Volcanic Rocks in Drill Holes USW GU-3 and USW G-3, Yucca Mountain, Nye County, Nevada," U.S. Geological Survey Open-File Report 84-491 (1984), YMP Accession No. NNA.870519.0095

Scott, R.B., R.W. Spengler, S. Diehl, A.R. Lappin and M.P. Chornack, "Geolrogic Character of Tuffs in the Unsaturated Zone at Yucca Mountain. Southern Nevada," Sandia National Laboratories report SAND 83-0143 in Role of the Unsaturated Zone in Radioactive and Hazardous Waste Disposal, James Mercer Ed. (Ann Artor Science, Ann Arbor, Michigan, 1983), YMP Accession No. HQS. 880517.1446

Site and Engineering Properties Database, Sandia National Laboratory, Product No. SEP0076 (1990a), YMP Accession No. NNA. 900614.0462

Site and Engineering Properties Database, Sandia National Laboratory, Product No. SEP0078 (1990b), YMP Accession No. NNA. 900807.0188

Sinnock, S. (Ed.), Y.T. Lin and M.S. Tierney, "Preliminary Estimates of Groundwater Travel Time and Radionuclide Transport at the Yucca Mountain Repository Site," Sandia National Laboratories report SAND 85-2701 (1986), YMP Accession No. HQS. 880517.1844

Sinnock, S., J.A. Fernandez and W.S. Twenhofel, "Attributes and Associated Favorability Graphs for the NNWSI Area-to-Location Screening Activity," Sandia National Laboratories report SAND 820838 (1984), YMP Accession No. HQS.880517.2867

Spengler, R.W. and M.P. Chornack, "Stratigraphic and structural Characteristics of Volcanic Rocks in Core Hole USW G4, Yucca Mountain, Nye County, Nevada," U.S. Geological Survey open-File Report 84-789 (1984), YMP Accession No. NNA.890804.0012

Spengler, R.W., F.M. Byers, Jr. and J.B. Warner, "Stratigraphy and structure of volcanic rocks in drill hole USW G-1, Yucca Mountain, Nye County, Nevada," U.S. Geological Survey Open-File Report 81-1349 (1981), YMP Accession No. HQS. 880517.1492

Spengler, R.W., D.C. Muller and R.B. Livermore, "Preliminary Report on the Geology and Geophysics of Drill Hole UE-25 A\#1, Yucca Mountain, Nevada Test Site," U.S. Geological Survey OpenFile Report 79-1244 (1979), YMP Accession NC. HQS.880517.1491 
Thordarson, W., "Geohydrologic Data and Test Results From Well J13, Nevada Test Site, Nye County, Nevada," U.S. Geological Survey Water Resources Investigation Report 83-4171 (1983), YMP

Accession No. NNA.870518.0071

Thordarson, W., F.E. Rush, R.W. Spengler and S.J. Waddell, "Geohydrologic and drill-hole data for test well UsW H-3, Yucca Mountain, Nye County, Nevada," U.S. Geological Survey open-File Report 84-149 (1984), YMP Accession No. NNA.870406.0056

Tien, P.L., M.D. Siegel, C.D. Updegraff, K.K. Wahi and R.V. Guzowski, "Repository Site Data Report for Unsaturated Tuff, Yucca Mountain, Nevada," U.S. Nuclear Regulatory Commission Report NUREG/CR-4110 (1985), YMP Accession No. HQS.880517.1853

van Genuchten, M.Th., "A Closed-Form Equation for Predicting the Hydraulic Conductivity of Unsaturated Soils," Soil Sci. Am. J. 44, 892-898 (1980), YMP Accession No. NNA.890522.0287

Yeh, T.-C. and L.W. Gelhar, "Unsaturated Flow in Heterogeneous Soils," in Role of the Unsaturated Zone in Radioactive and Hazardous Waste Disposal, J.W. Mercer et al., Eds. (Ann Arbor Science, Ann Arbor, Michigan, 1983) 71-79, YMP Accession No. NNA. 920320.0024

Yeh, T.-C., L.W. Gelhar and A.L. Gutjahr, "Stochastic Analysis of Unsaturated Flow in Heterogeneous Soils 3. Observations and Applications," Water Resources Research 21, 9, 465-471 (1985), YMP Accession No. NNA. 920320.0025

Wang, J.S.Y. and T.N. Narasimhan, "Hydrologic Mechanisms Governing Partially Saturated Fluid Flow in Fractured Welded Units and Porous Nonwelded Units at Yucca Mountain," Sandia National Laboratories report SAND 85-7114 (1986), YMP Accession No. HQS.880517.2900

Whitfield, M., "Vacuum Drilling of Unsaturated Tuffs at a Potential Radioactive-Waste Repository, Yucca Mountain, Nevada," in Characterization and Monitoring of the Vadose (Unsaturated)

Zone (National Water Well Association, 1985) 412-423, YMP Accession No. NNA.870407.0327

Whitfield, M.S., Jr., W. Thordarson and E.P. Eshom, "Geohydrologic and Drill-Hole Data for Test Well USW H-4, Yucca Mountain, Nye County, Nevada," U.S. Geological Survey Open-File Report 84-449 (1984), YMP Accession No. NNA.870407.0317

Winograd, I.J. and W. Thordarson, "Hydrogeologic and Hydrochemical Framework, South-Central Great Basin, NevadaCalifornia, with Special Reference to the Nevada Test Site," U.S. Geological Survey Professional Paper 712-C (1975), YMP Accession No. HQS.880517.2908 
U.S. Department of Energy, Office of Civilian Radioactive Waste Management, Site Characterization Plan, Yucca Mountain Site, Nevada Research and Development Area, Nevada I (1988), YMP Accession NO. HQ0.881201.0002

U.S. Department of Energy, office of Civilian Radioactive Waste Management, Site Characterization Plan, Yucca Mountain Site, Nevada Research and Development Area, Nevada II (1988), YMP Accession No. HQO.881201.0002

U.S. Geological Survey, "A Summary of Geologic studies Through January 1, 1983, of a Potential High-Level Radioactive Waste Repository Site at Yucca Mountain, Southern Nye County, Nevada," U.S. Geological Survey Open-File Report USGS OFR-84-792 (1984), YMP Accession No. HQS.880517.1538

Zimmerman, R.M., "First Phase of Small Diameter Heater Experiments in Tuff," Proc. 24th U.S. Symposium on Rock Mechanics, (Texas A\&M University, June 1983) 271-282, YMP Accession No. NNA.870406.0162 


\begin{abstract}
APPENDIX A
RELATIVE ABUNDANCE OF MINERALS AND GLASS
\end{abstract}

IN SELECTED WELLS AT YUCCA MOUNTAIN, NEVADA

AFTER BISH AND CHIPERA, 1989 


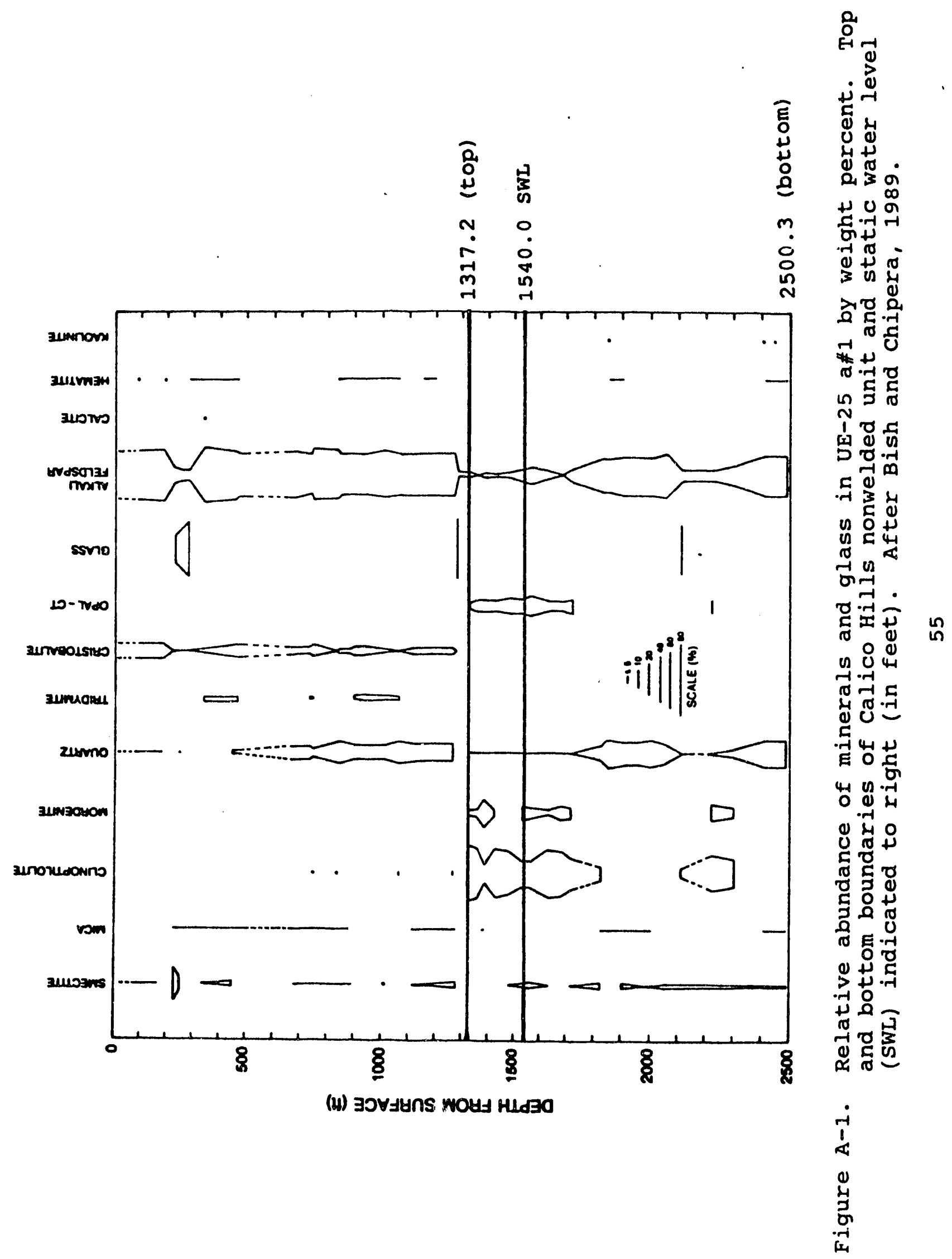




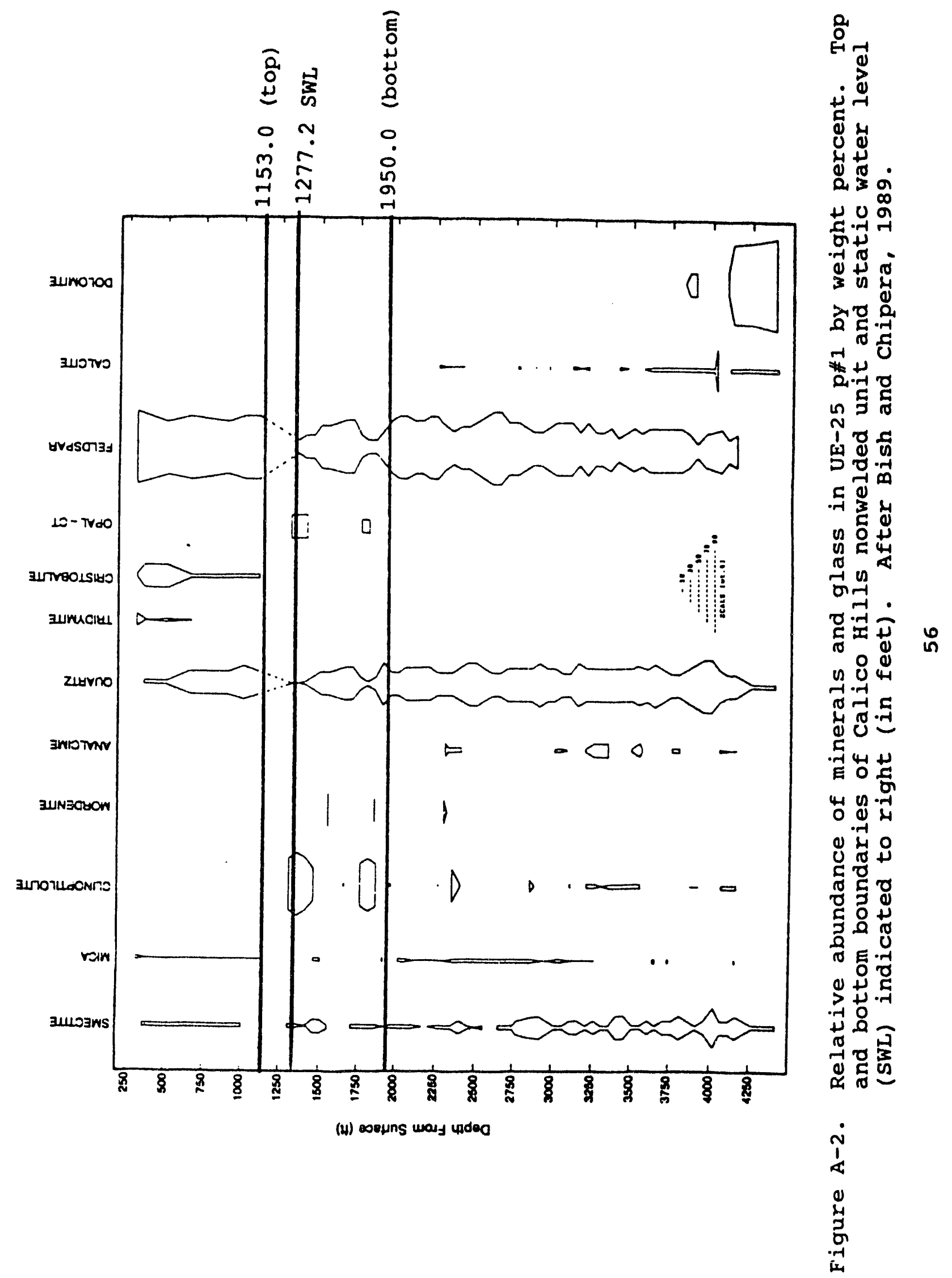




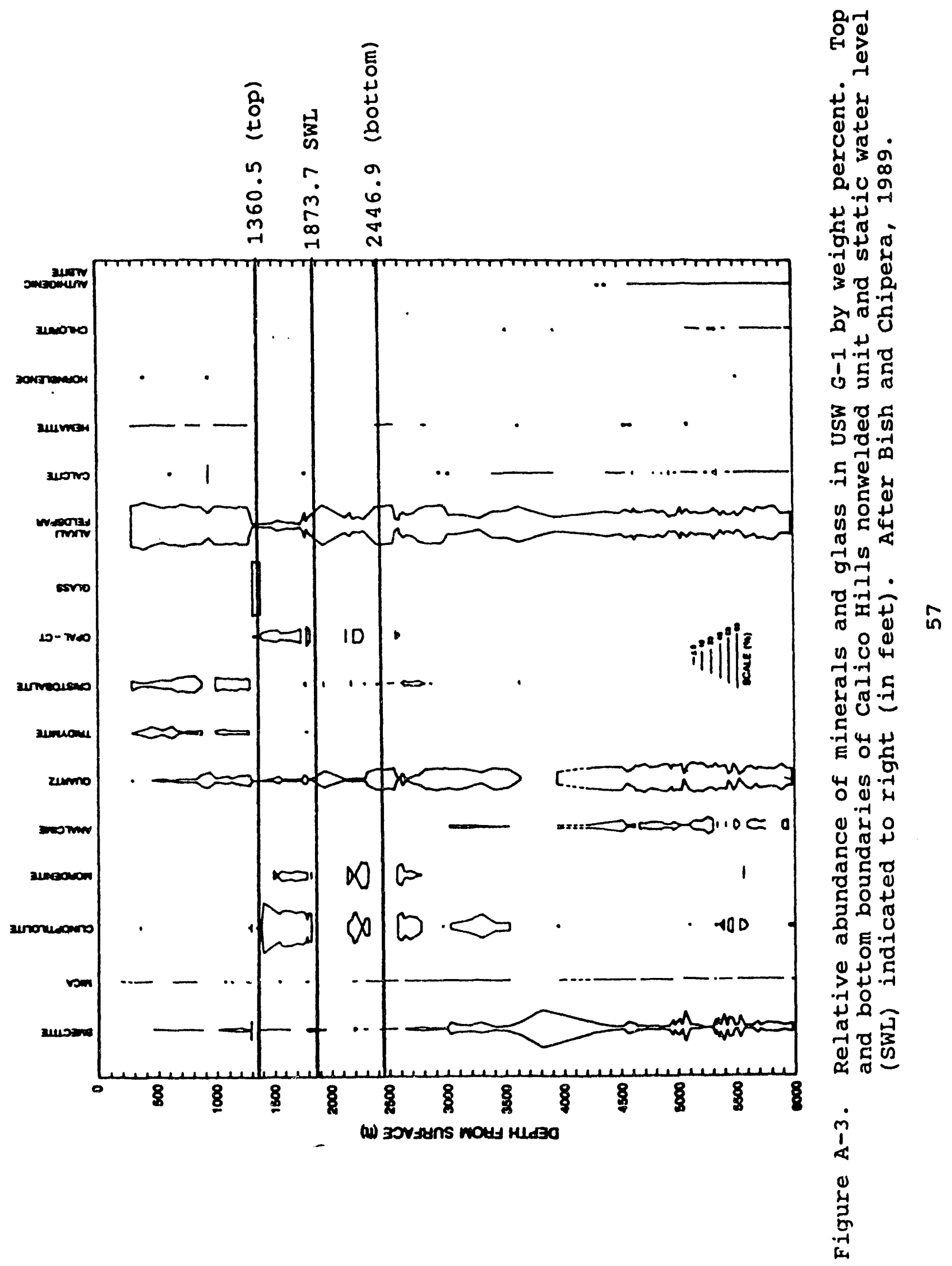




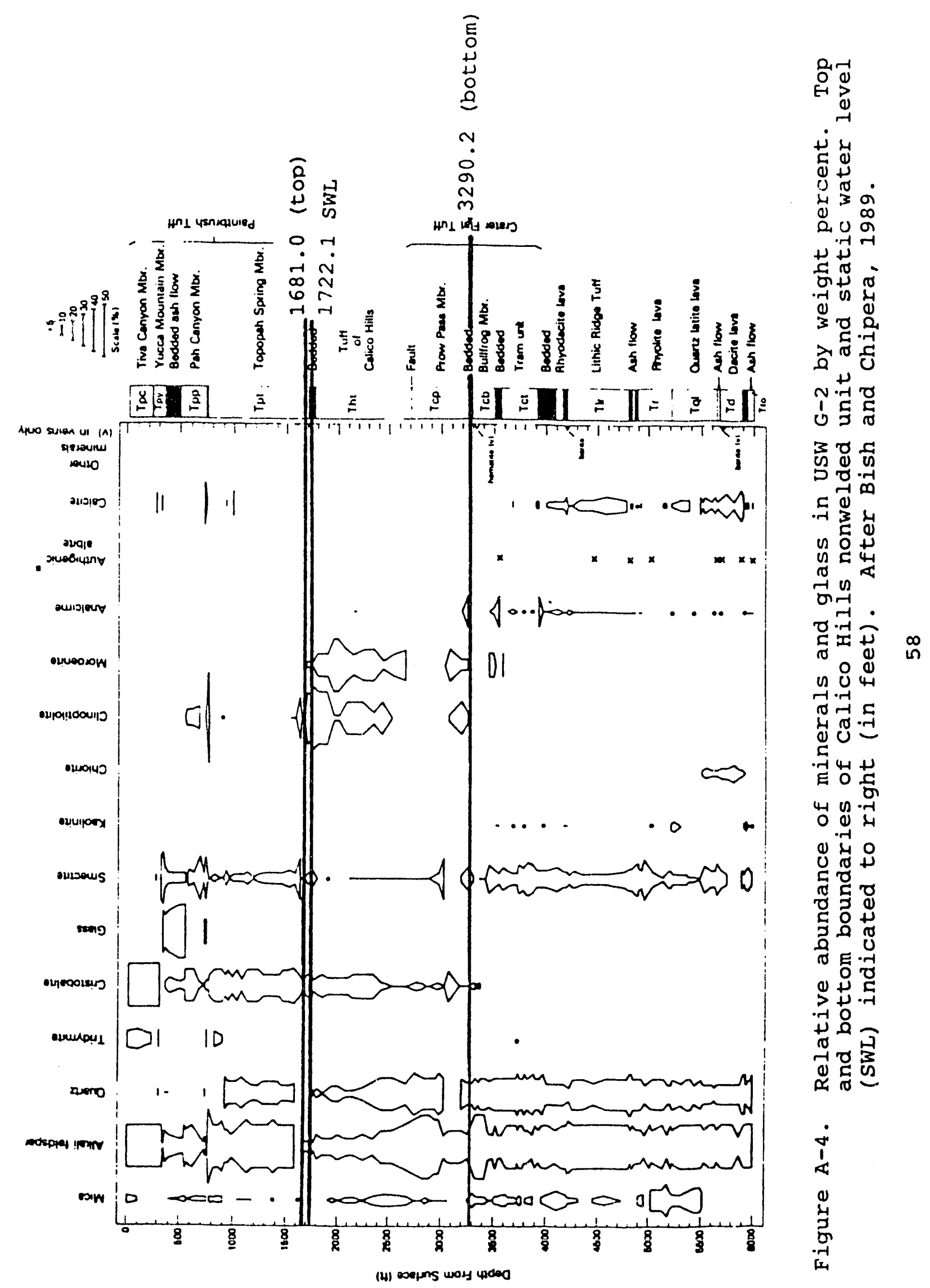




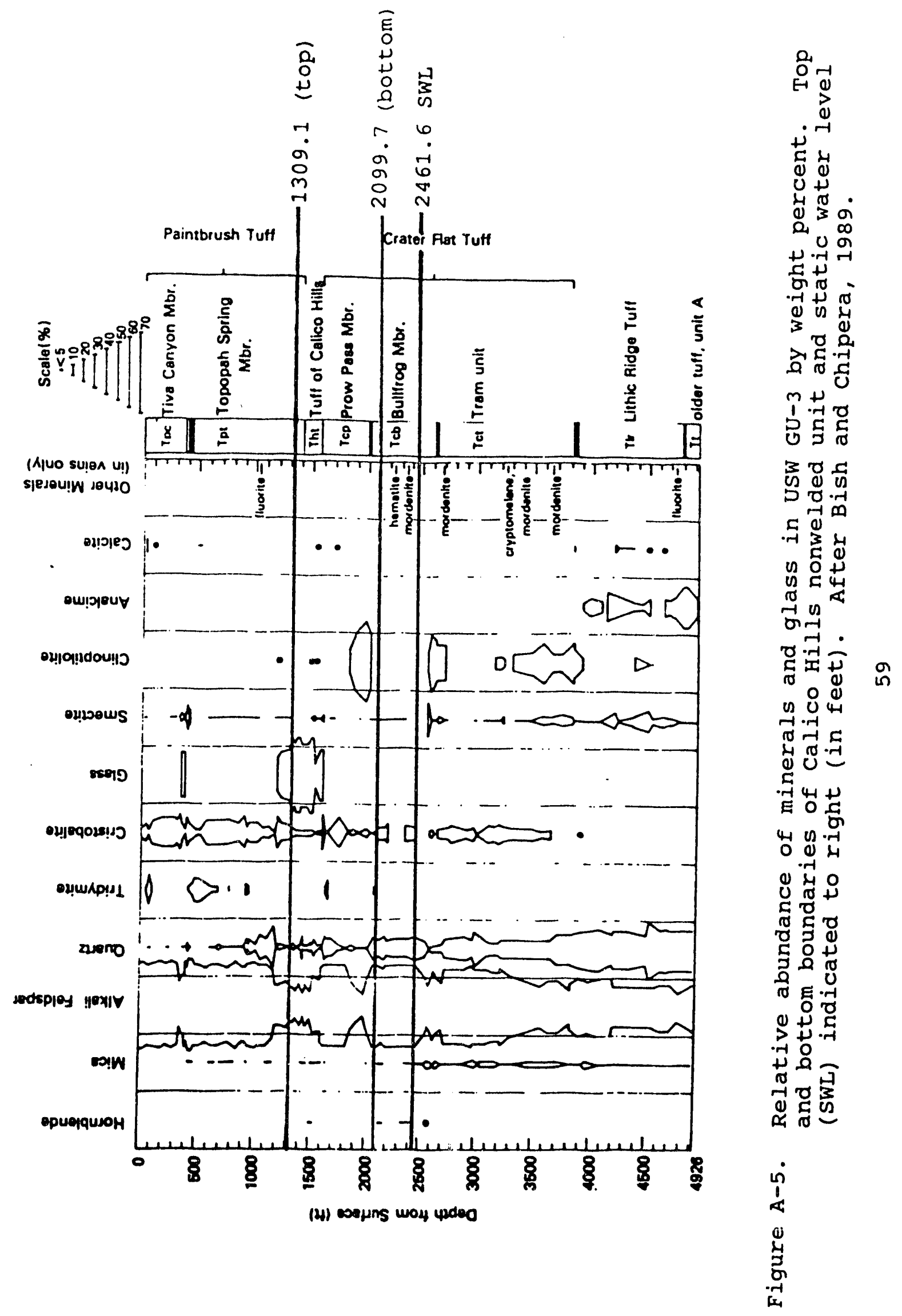




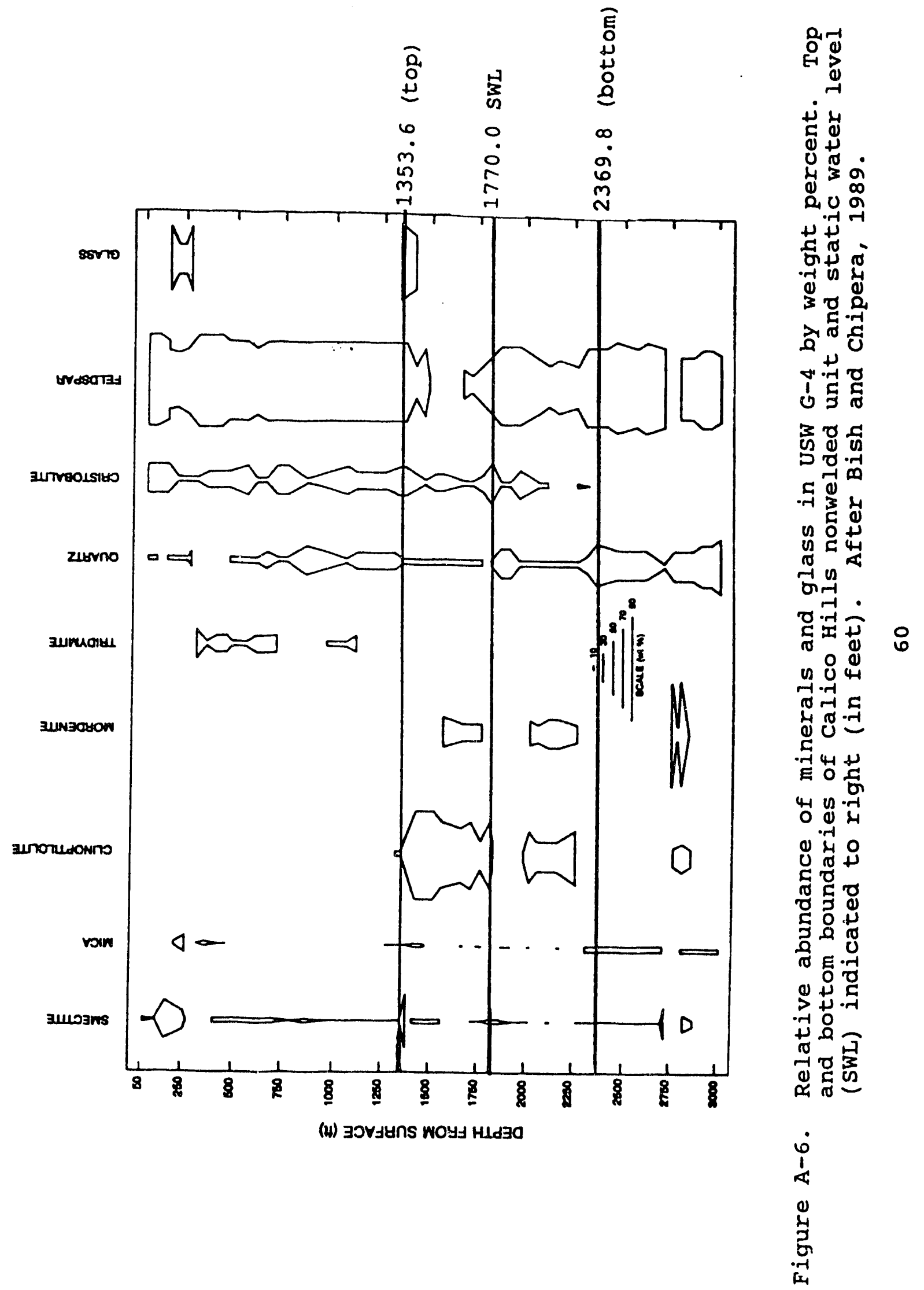




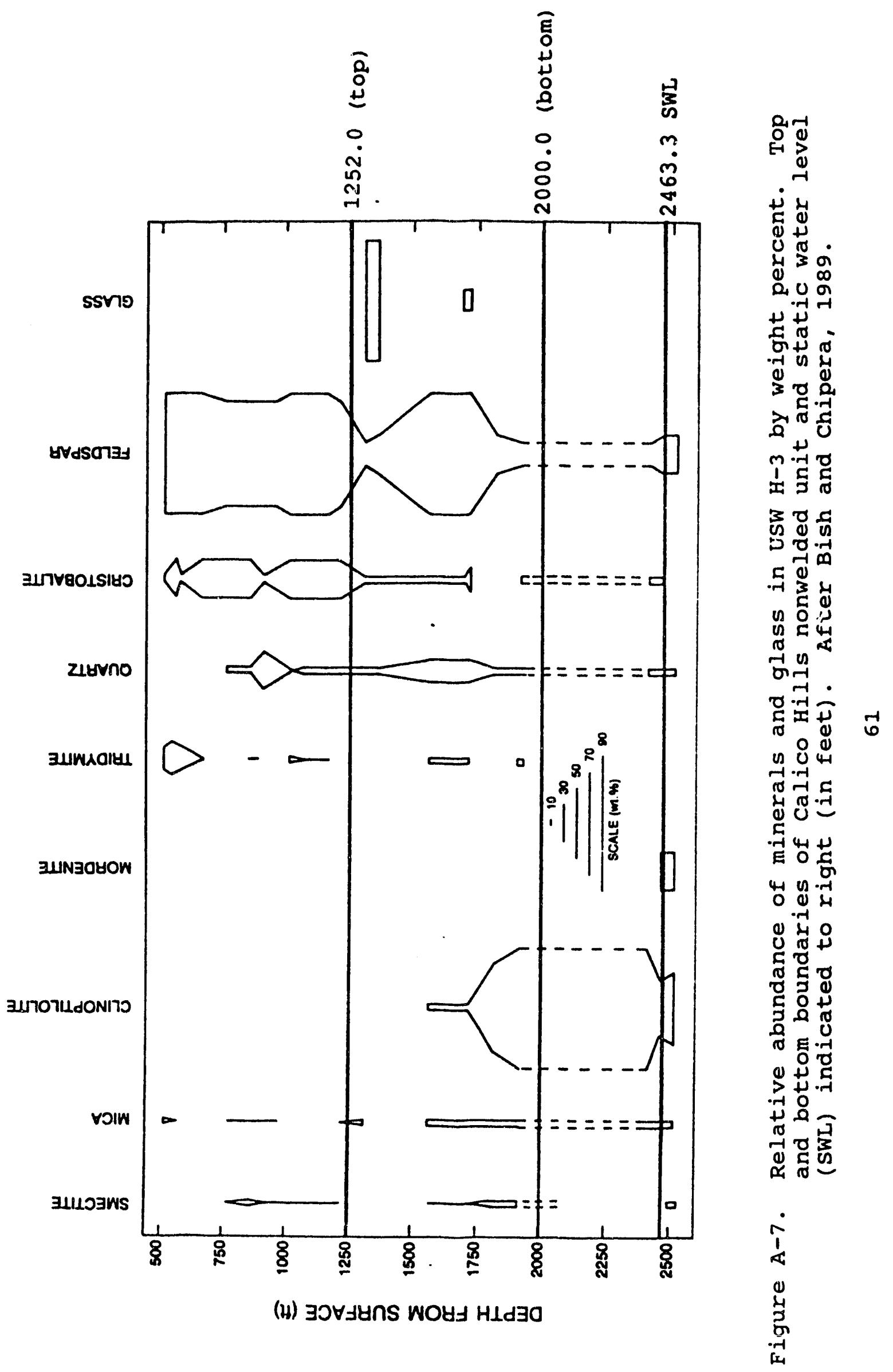




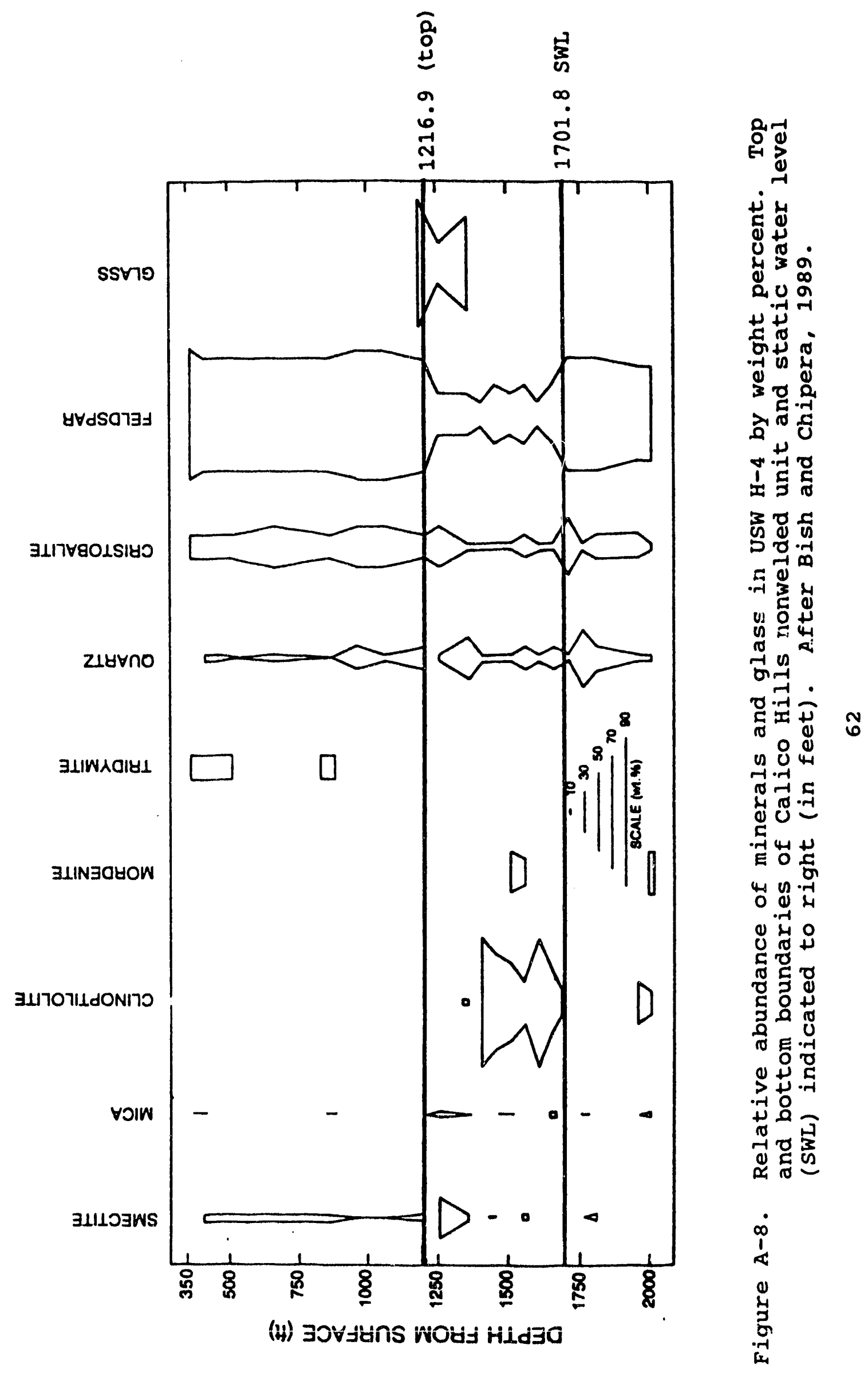




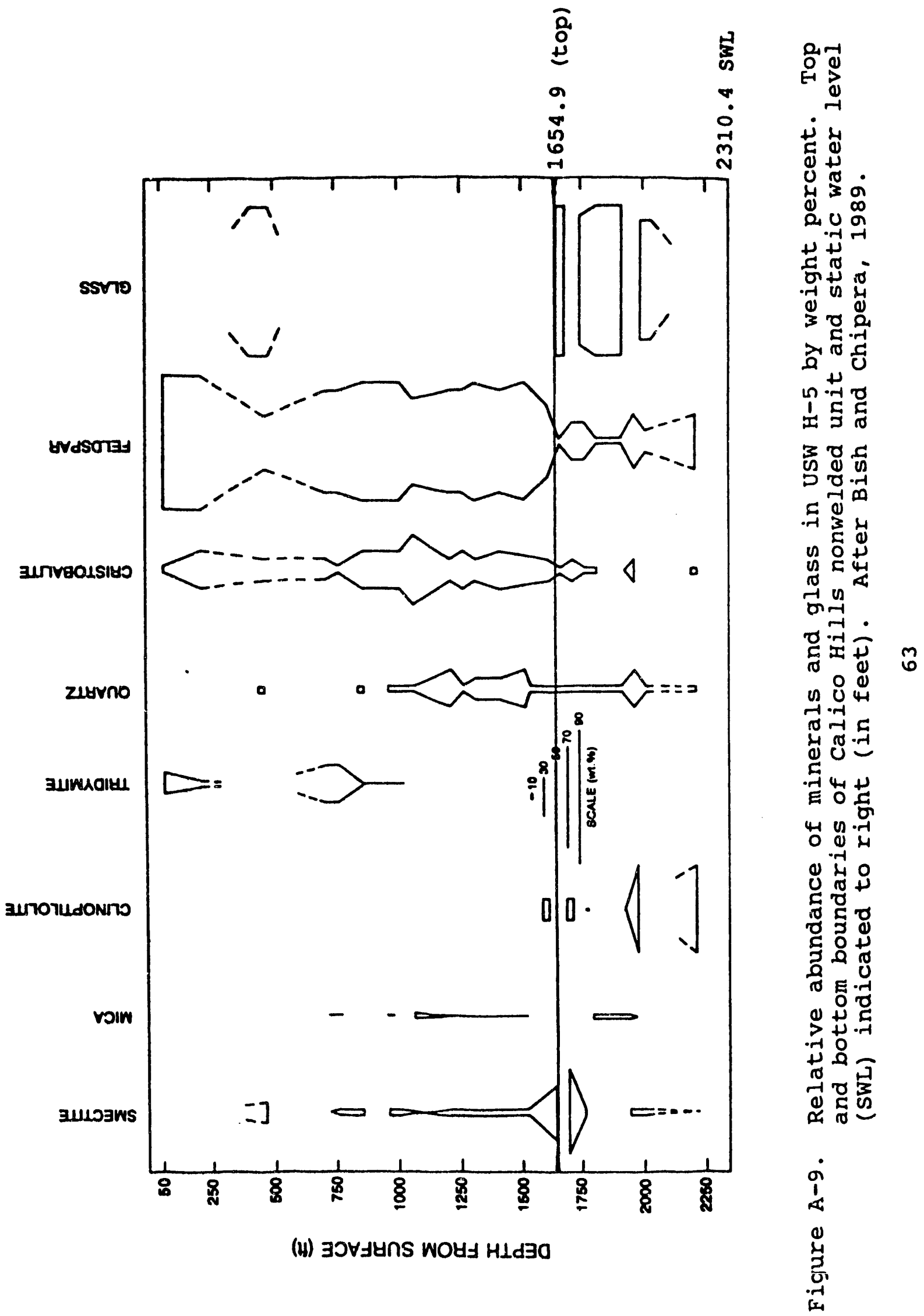




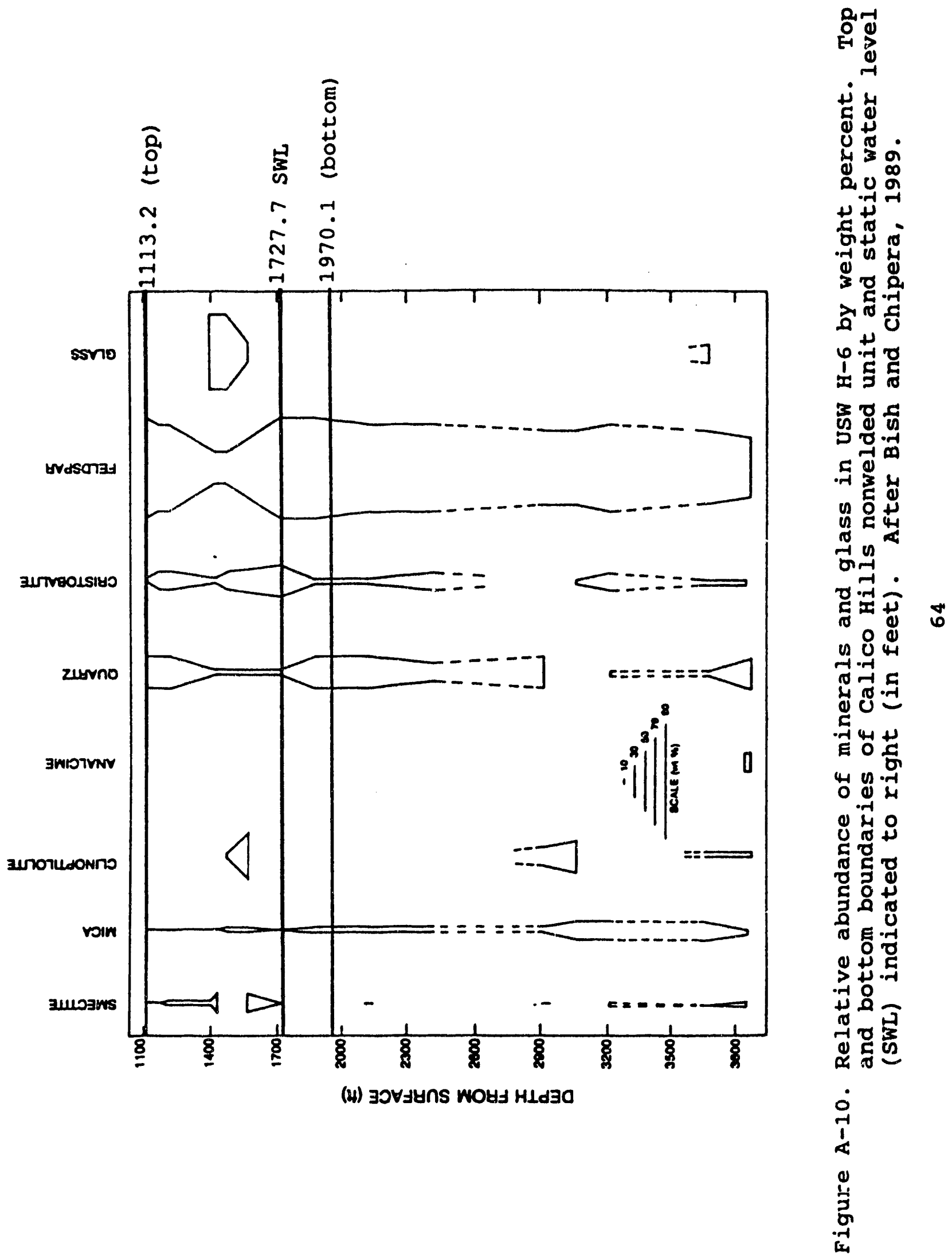




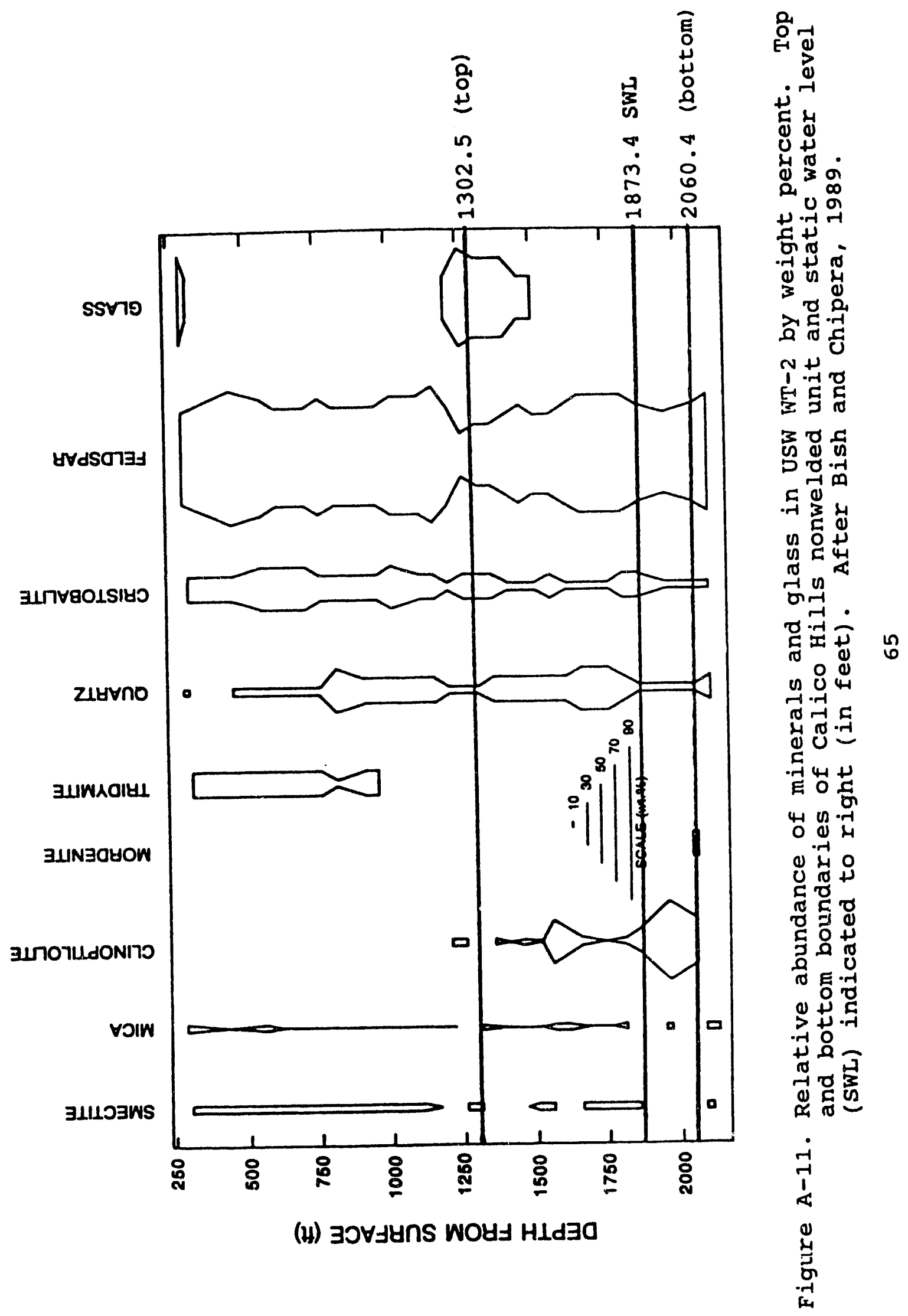




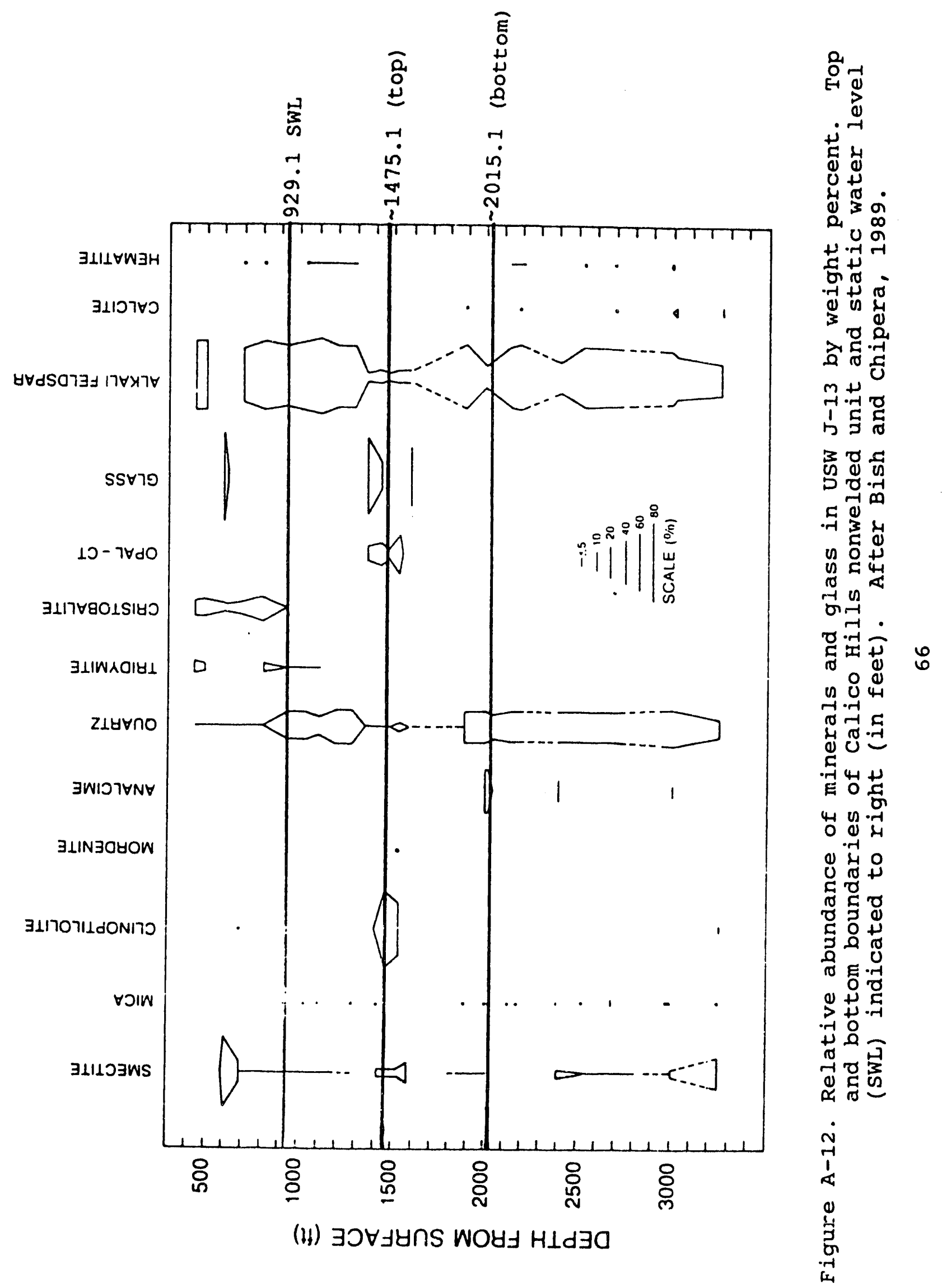




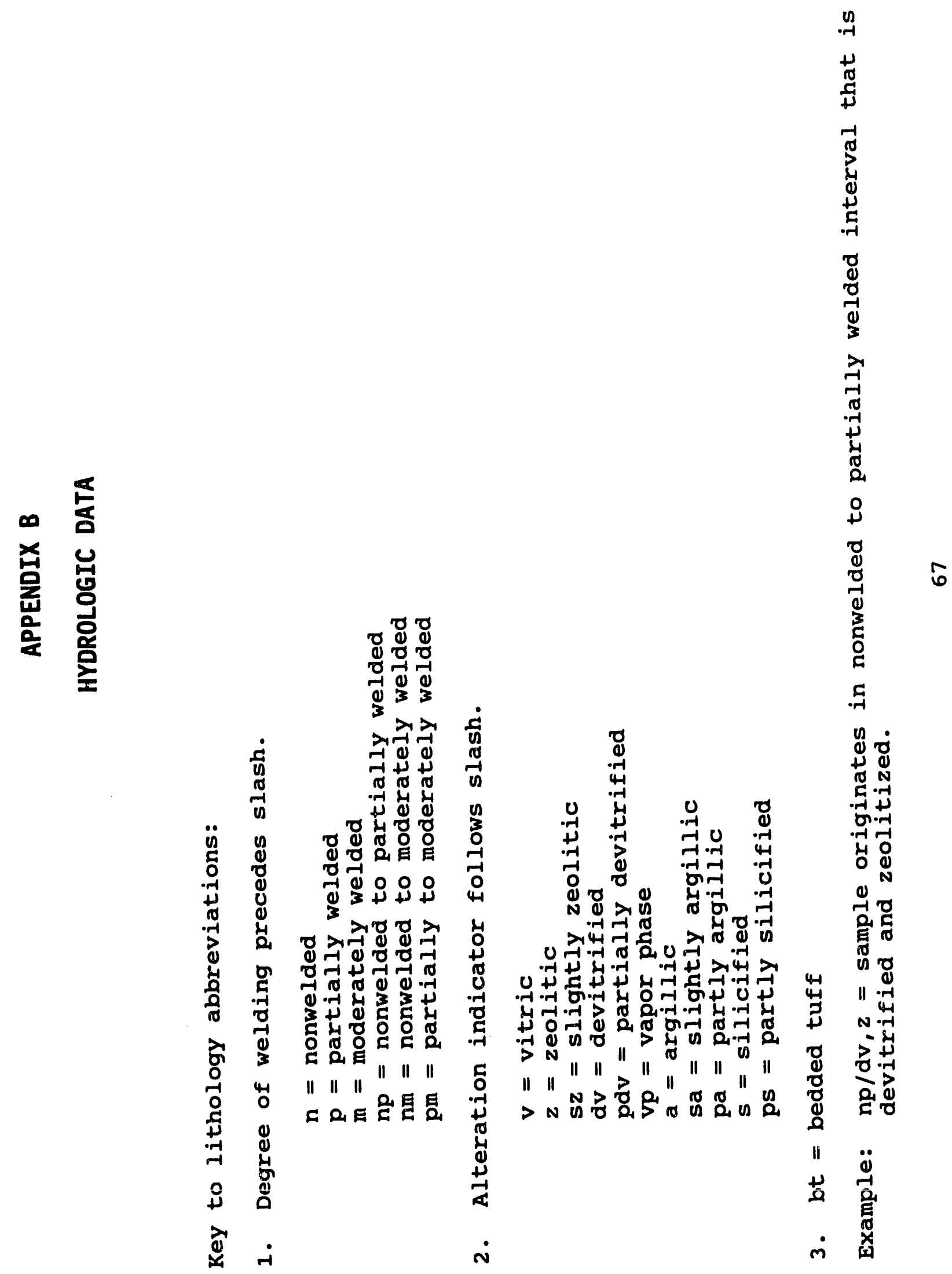




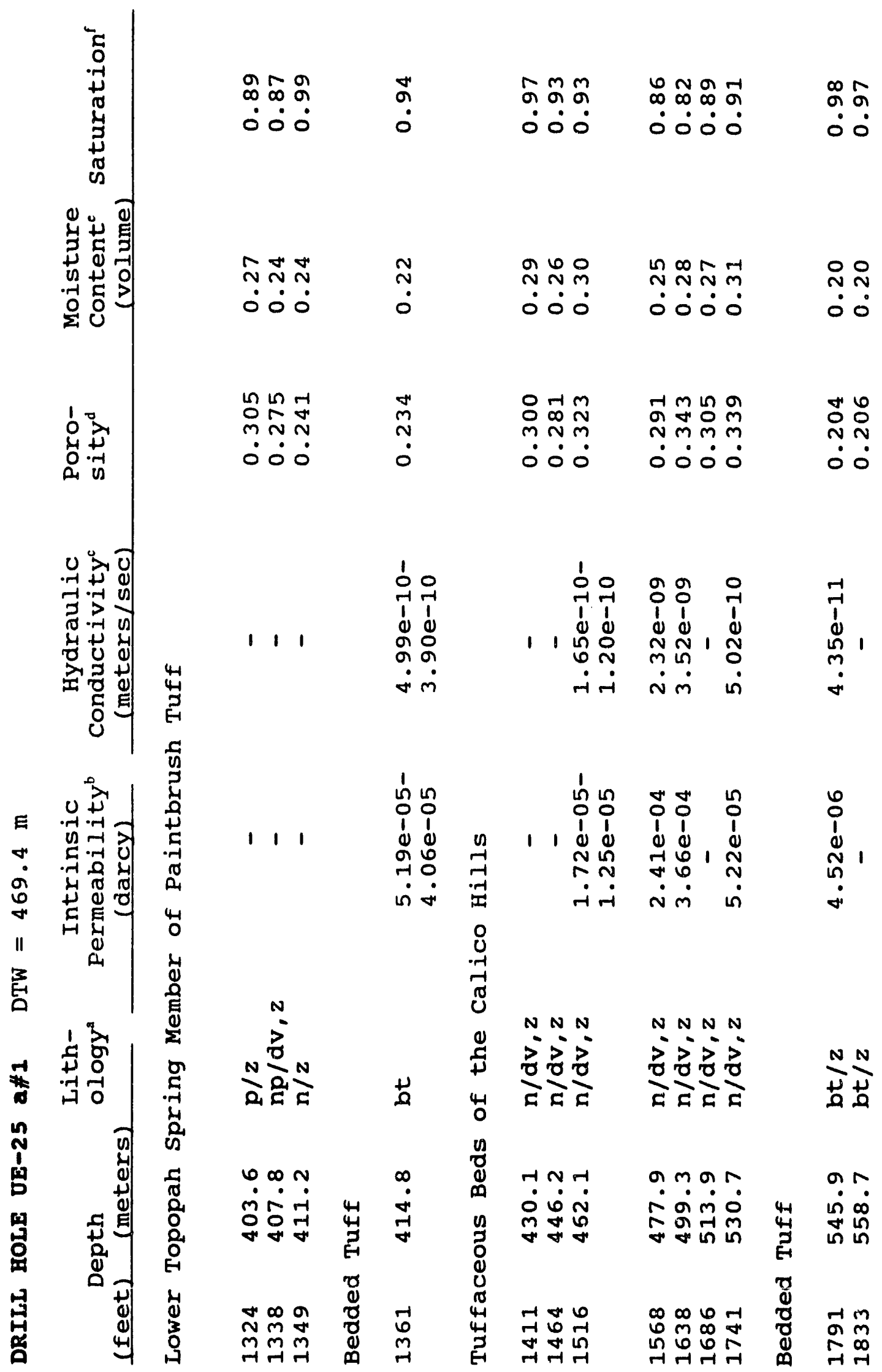




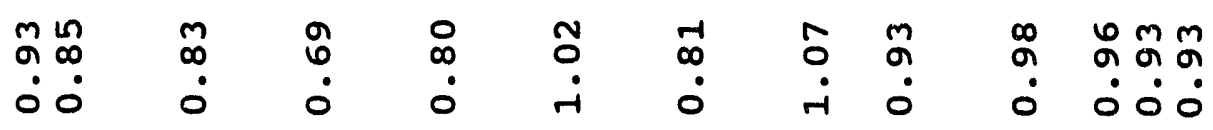

a

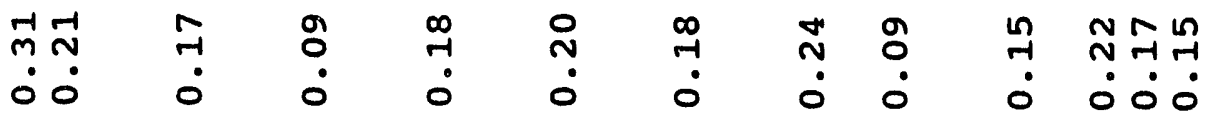

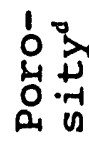

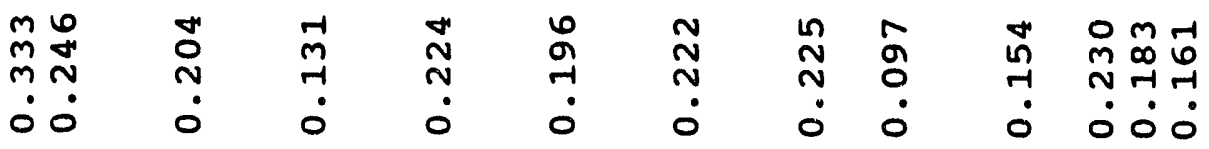

$0: 0$

$\rightarrow \rightarrow-10$

क्ष

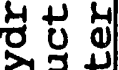

经通

国

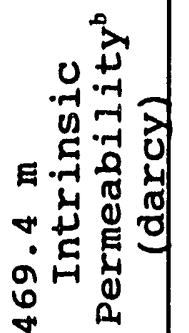

$\stackrel{1}{\infty} \infty$

1

\author{
.
}

욱윽

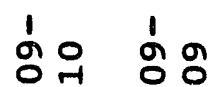

1 11 i 1

1)

ڤஸ்

ถูก

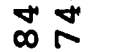

N-1

लक बूँ

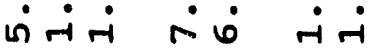

in $\dot{\sim} \dot{\sim}$

$\dot{v} \dot{v}$

의요

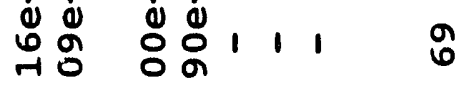

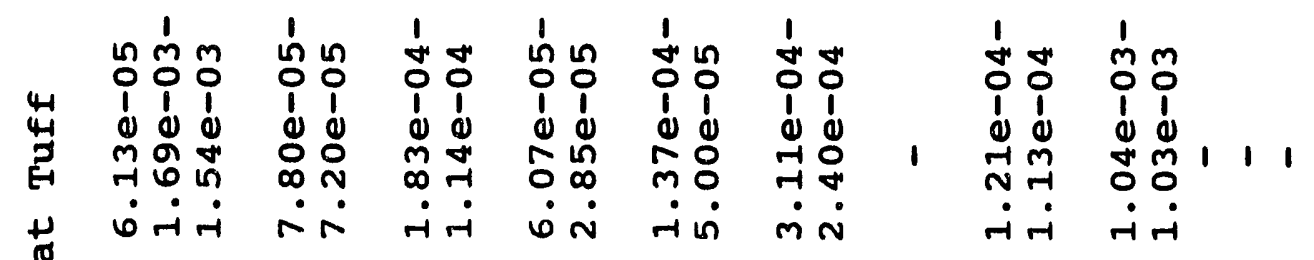

II

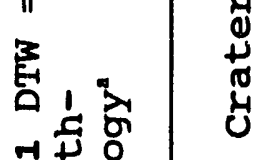

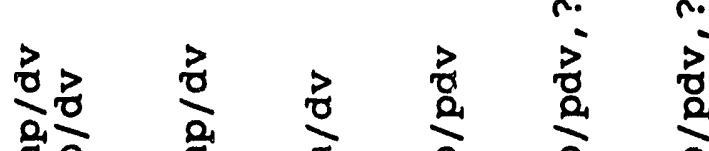

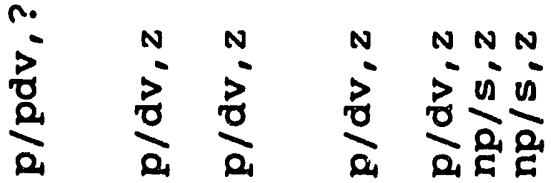

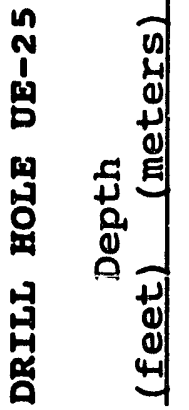

品

نே.

$\begin{array}{ll}0 & 0 \\ 0 & 0 \\ 0 & 0\end{array}$

$\begin{array}{ll}\stackrel{n}{m} & \dot{m} \\ \dot{0} & \stackrel{\sim}{0}\end{array}$

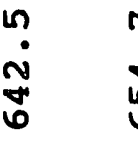

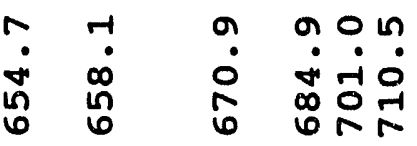

品 出

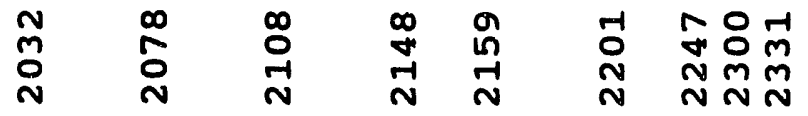




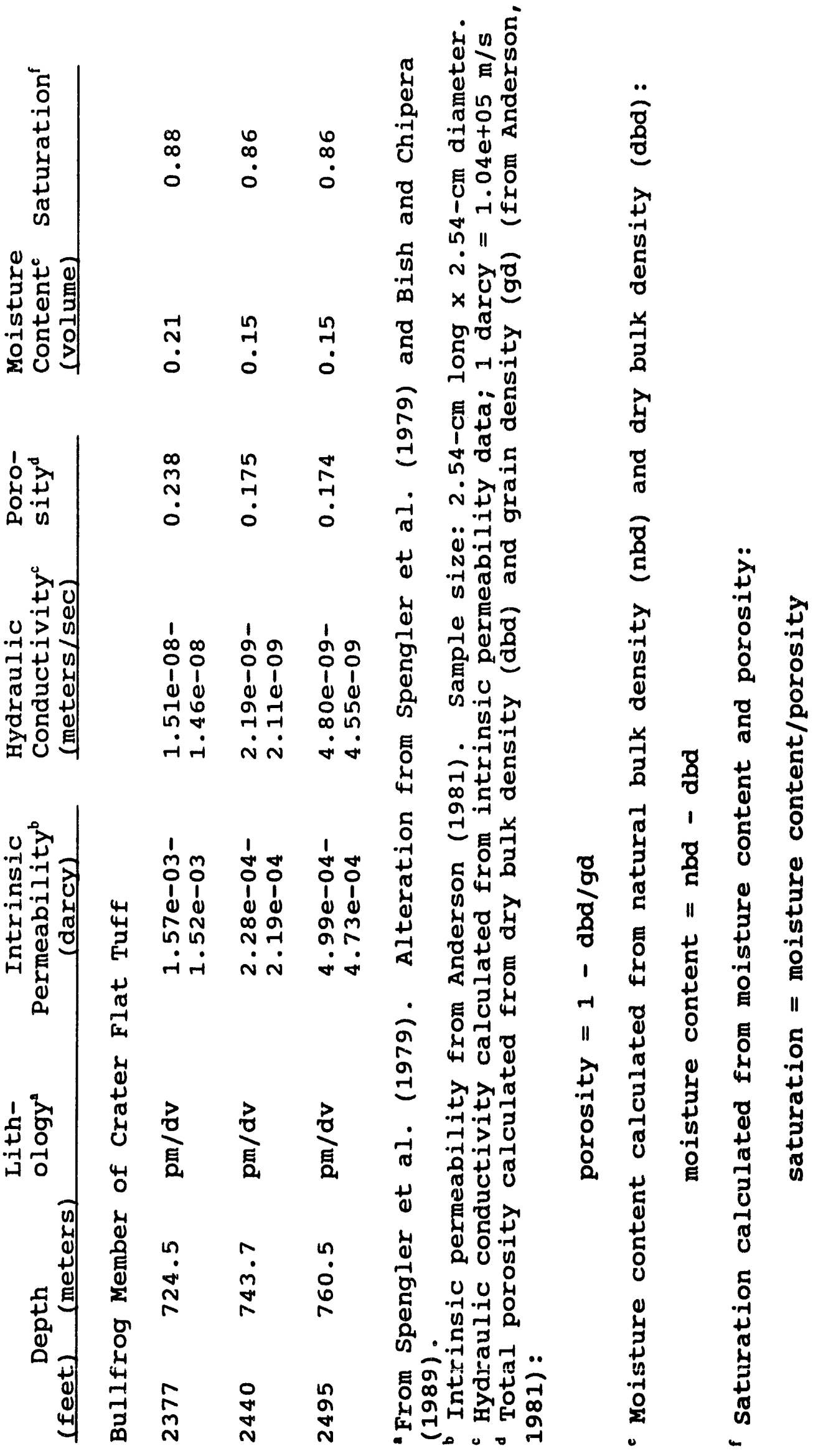




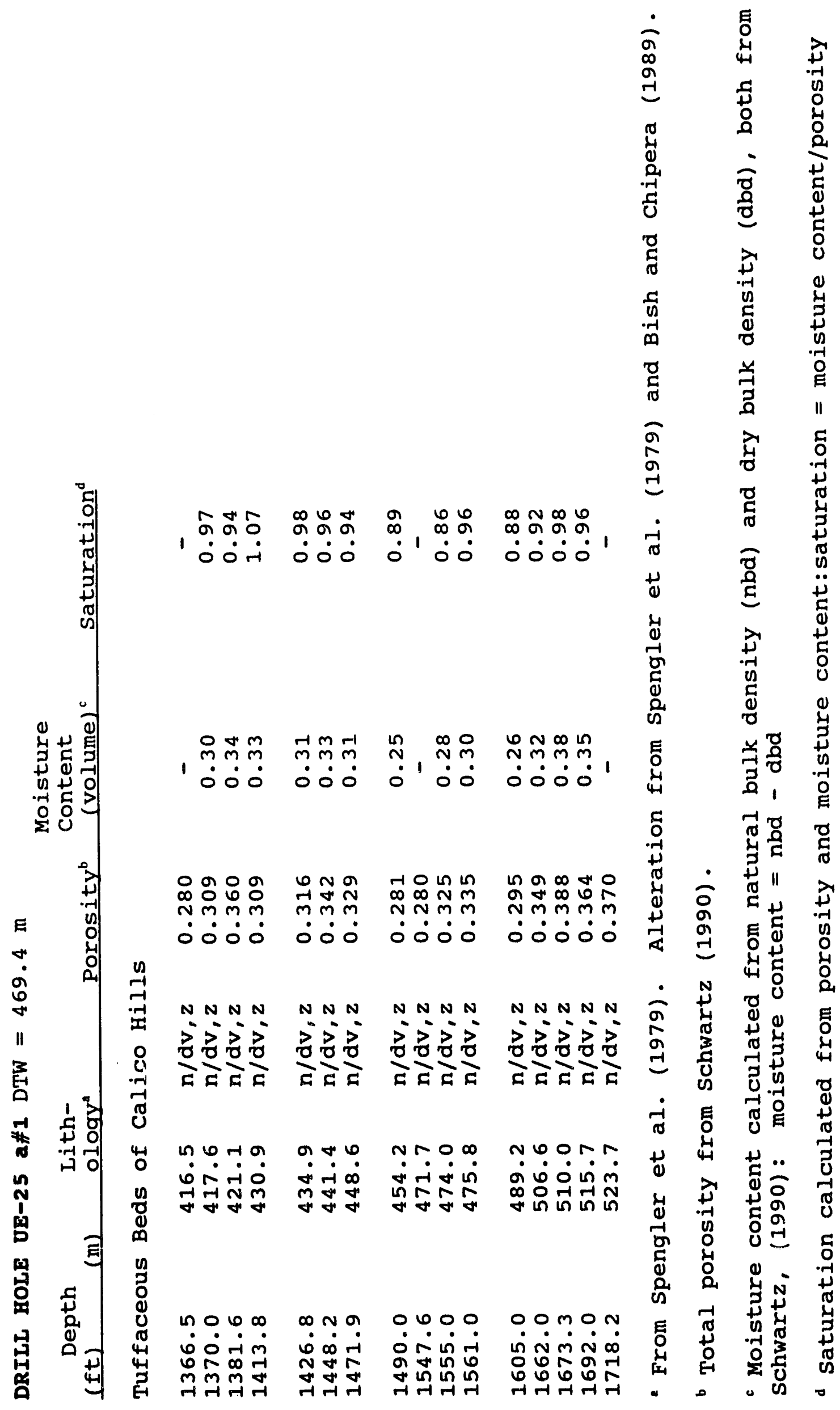




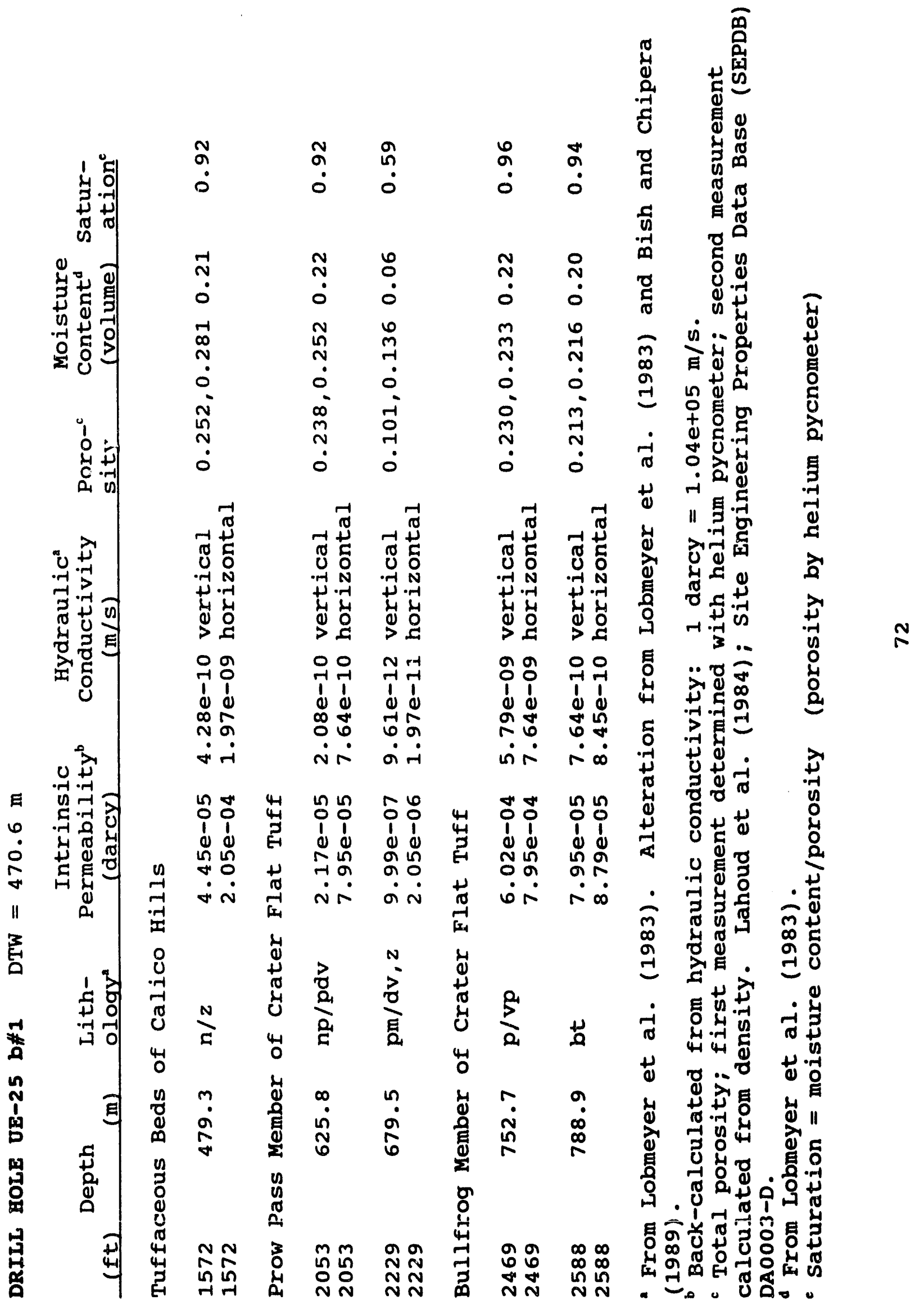




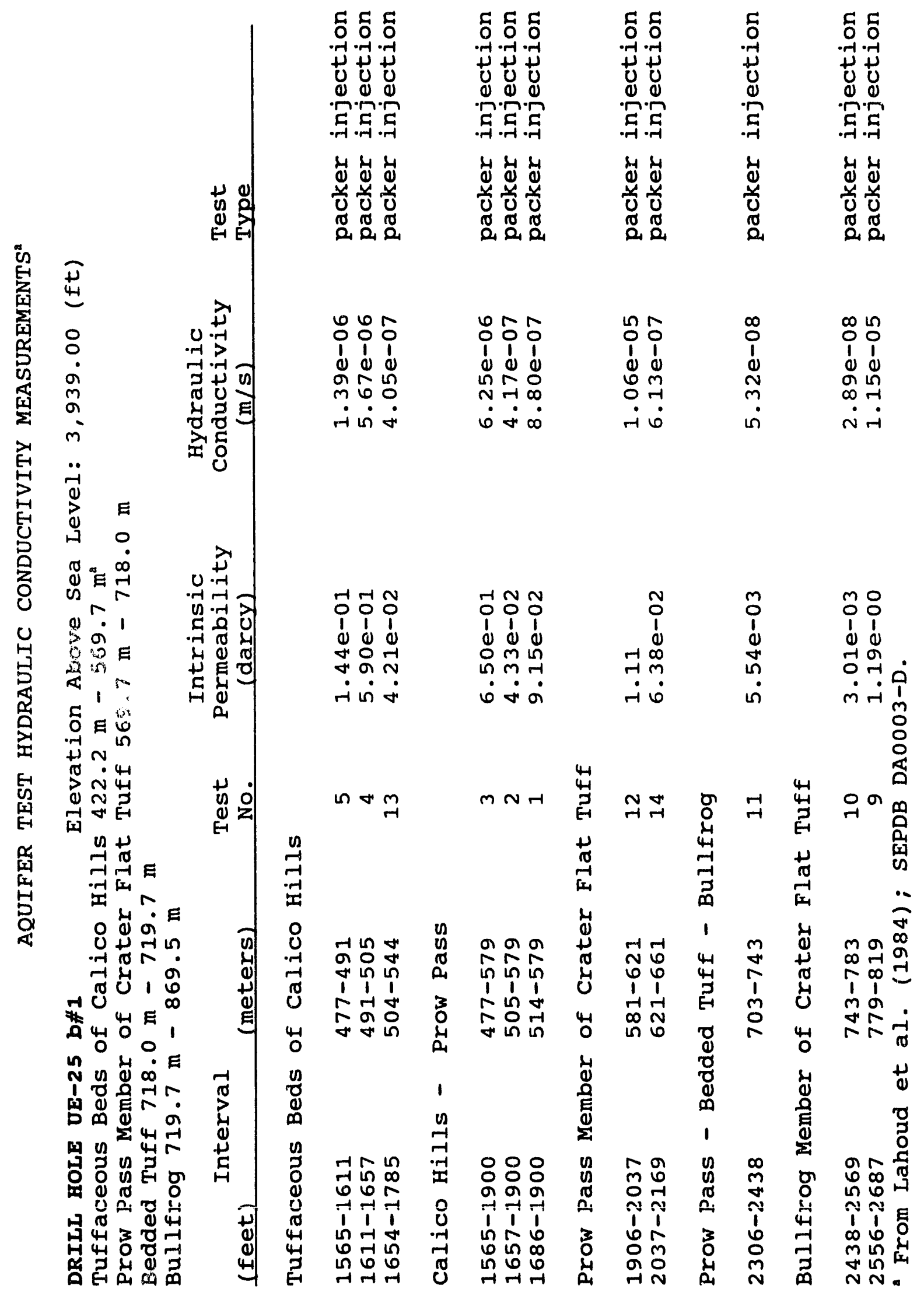




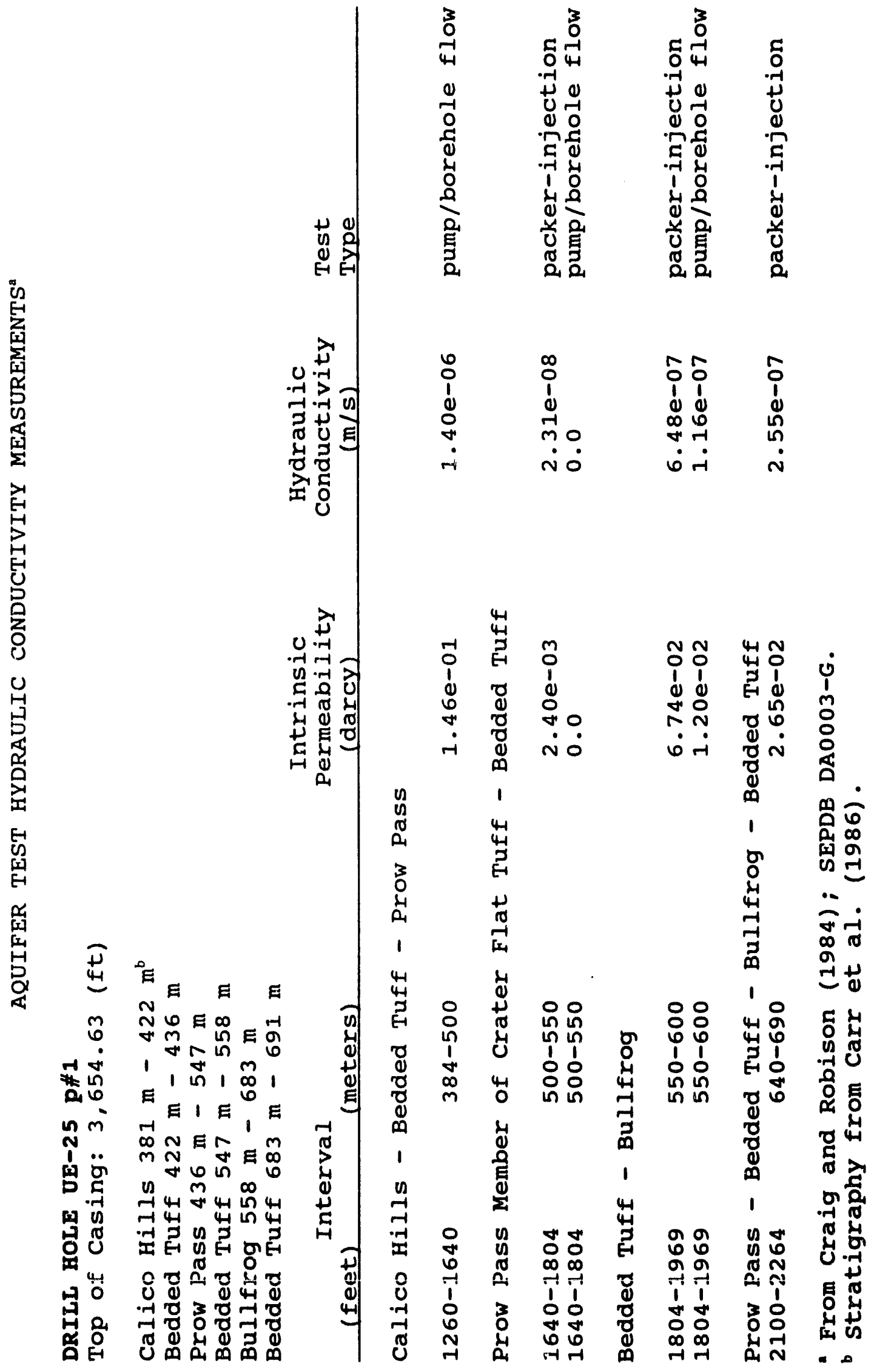




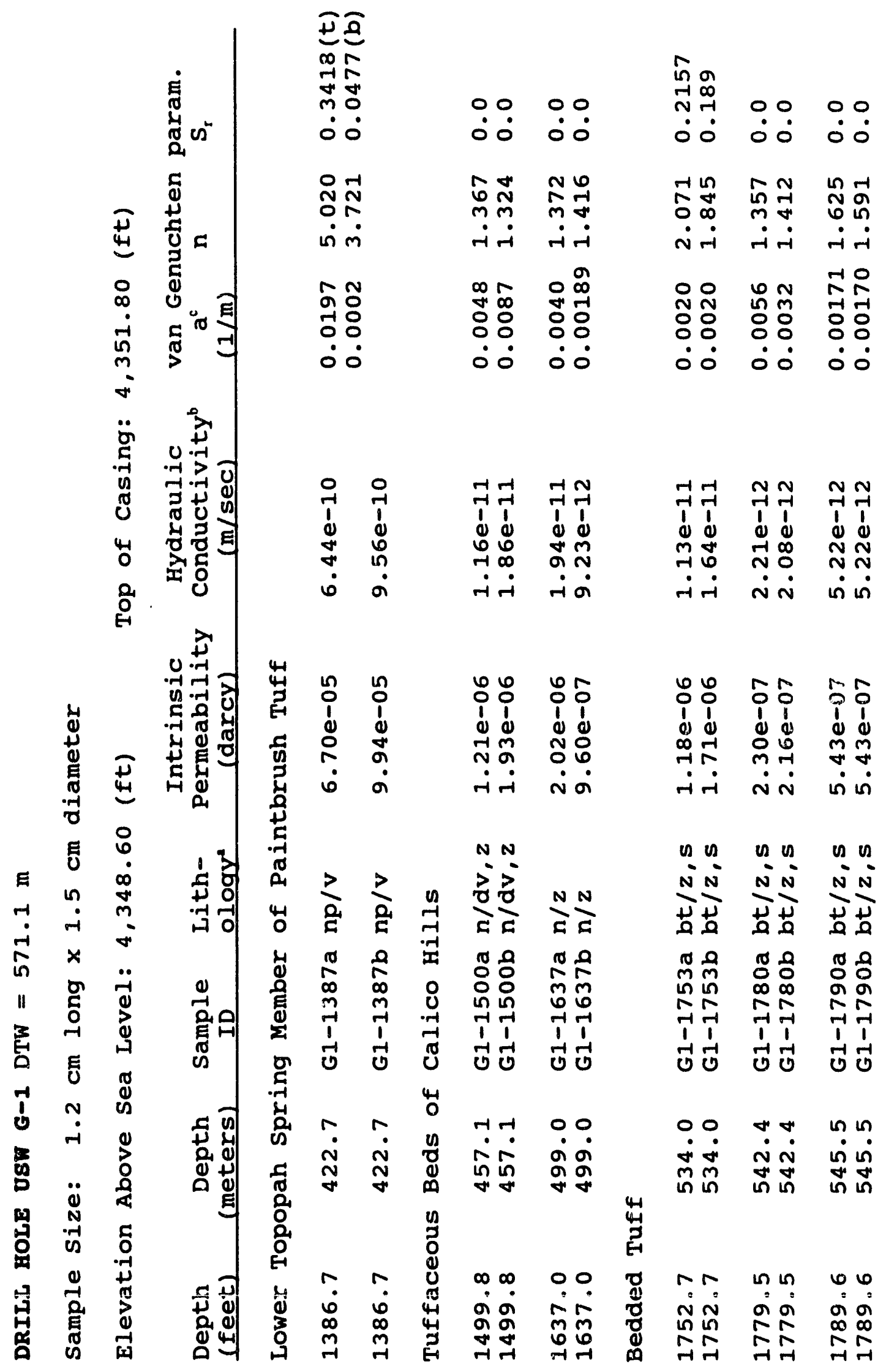




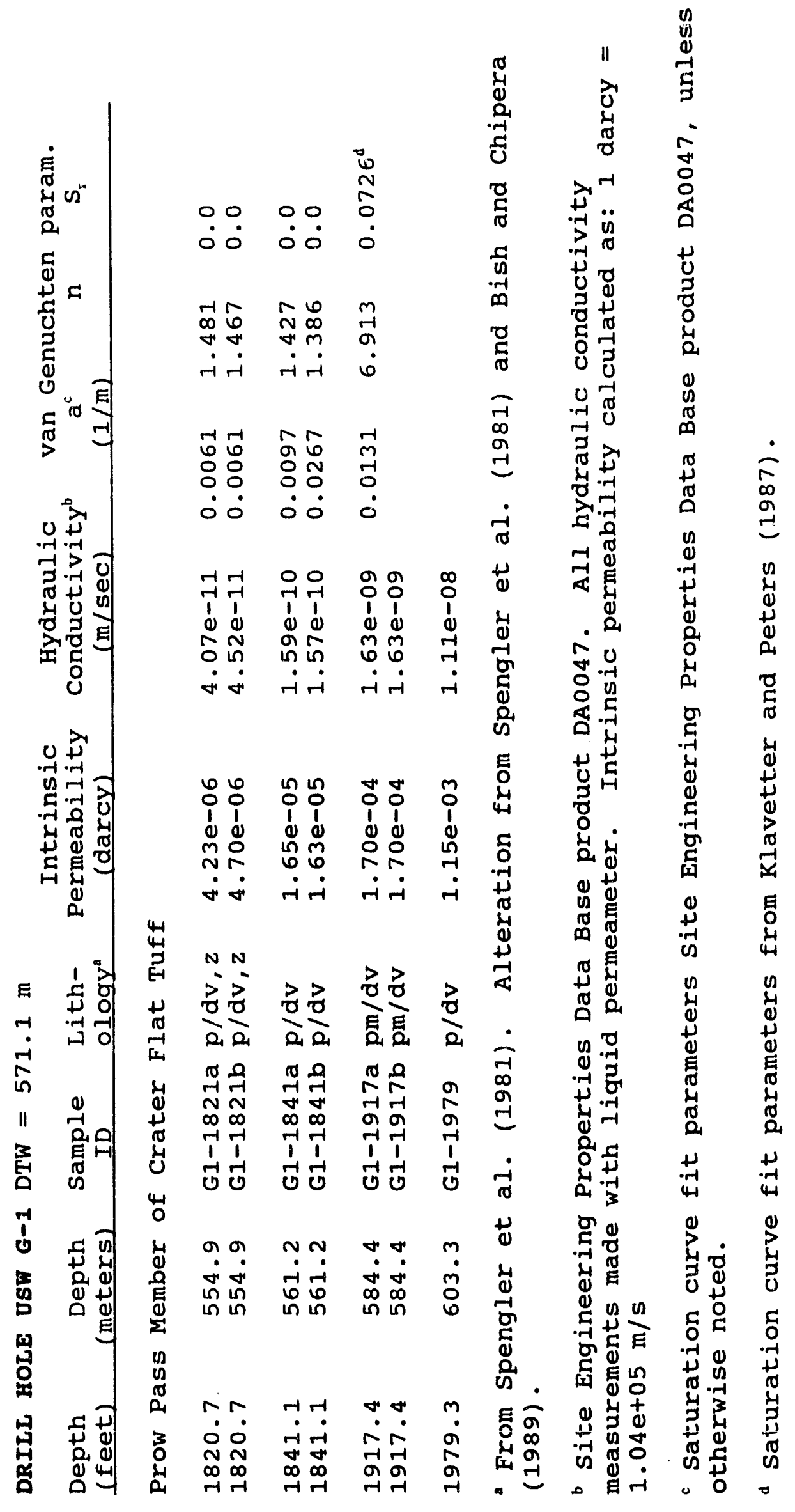

$\stackrel{0}{r}$ 


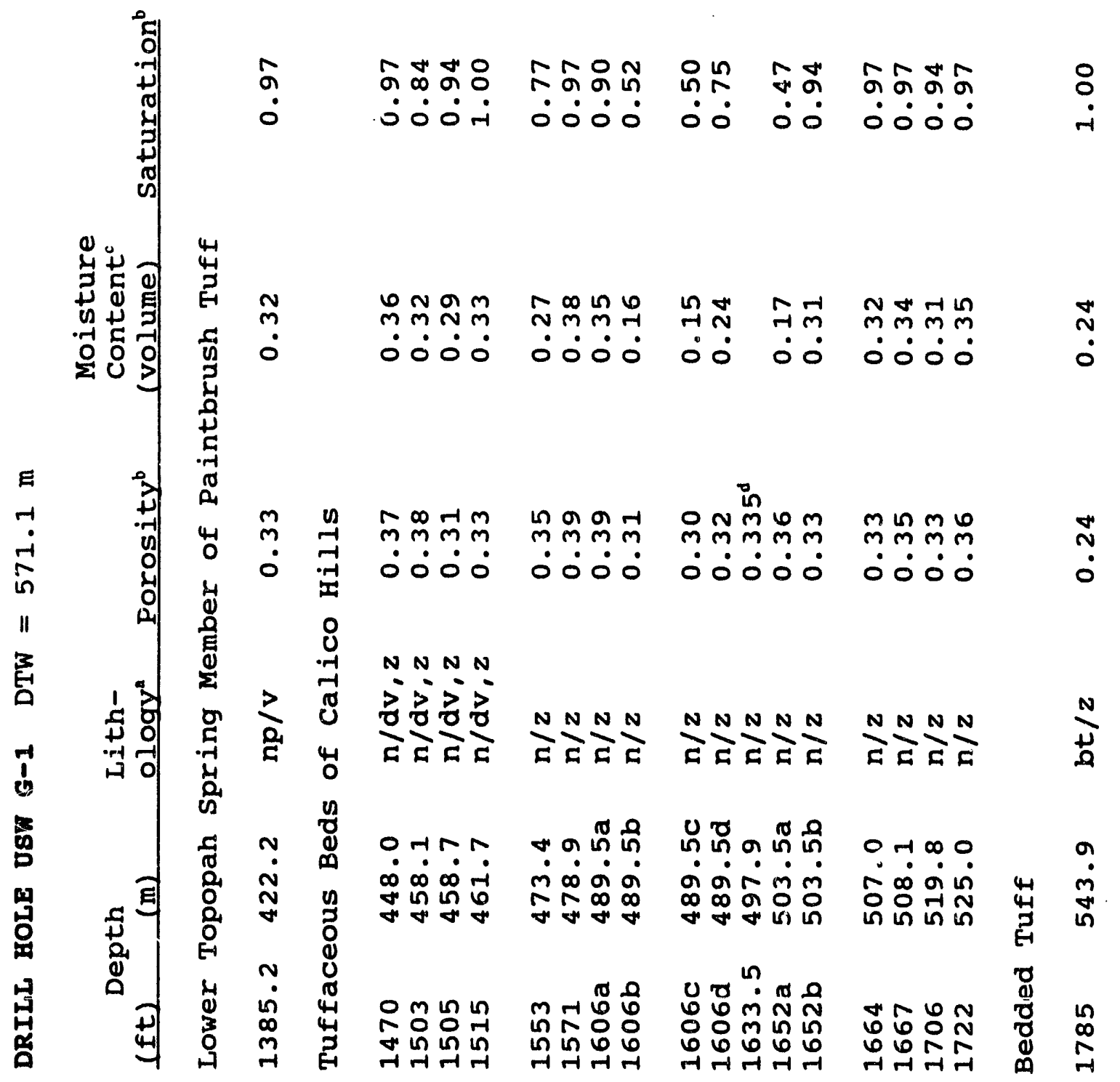




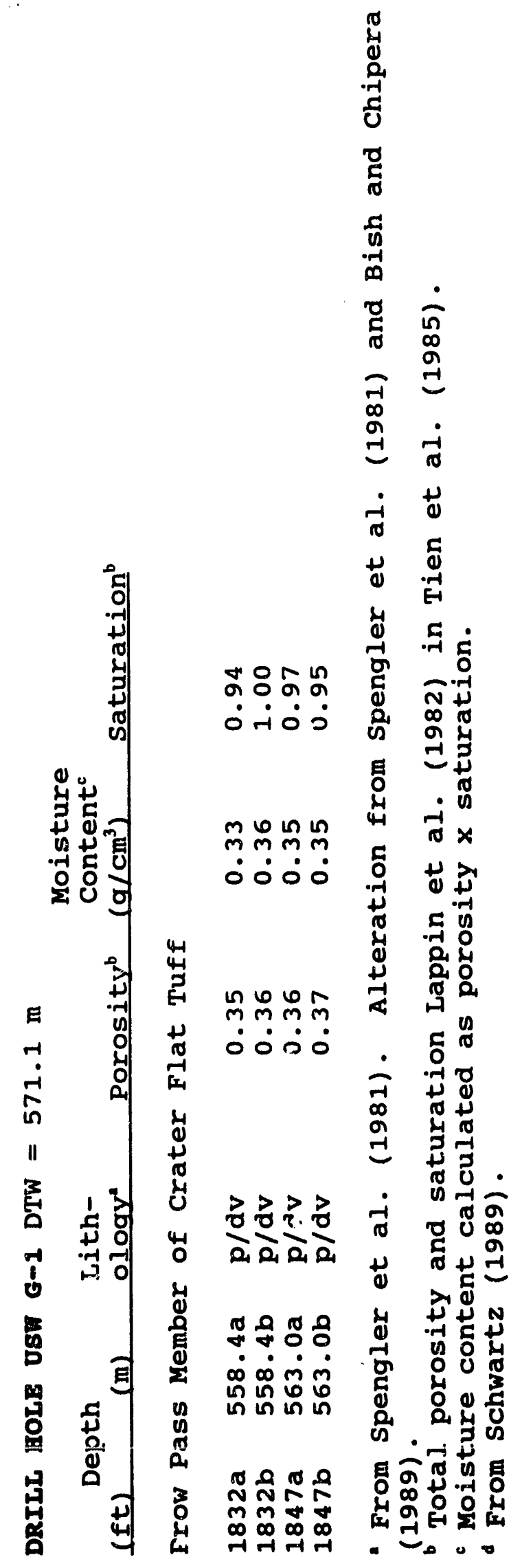




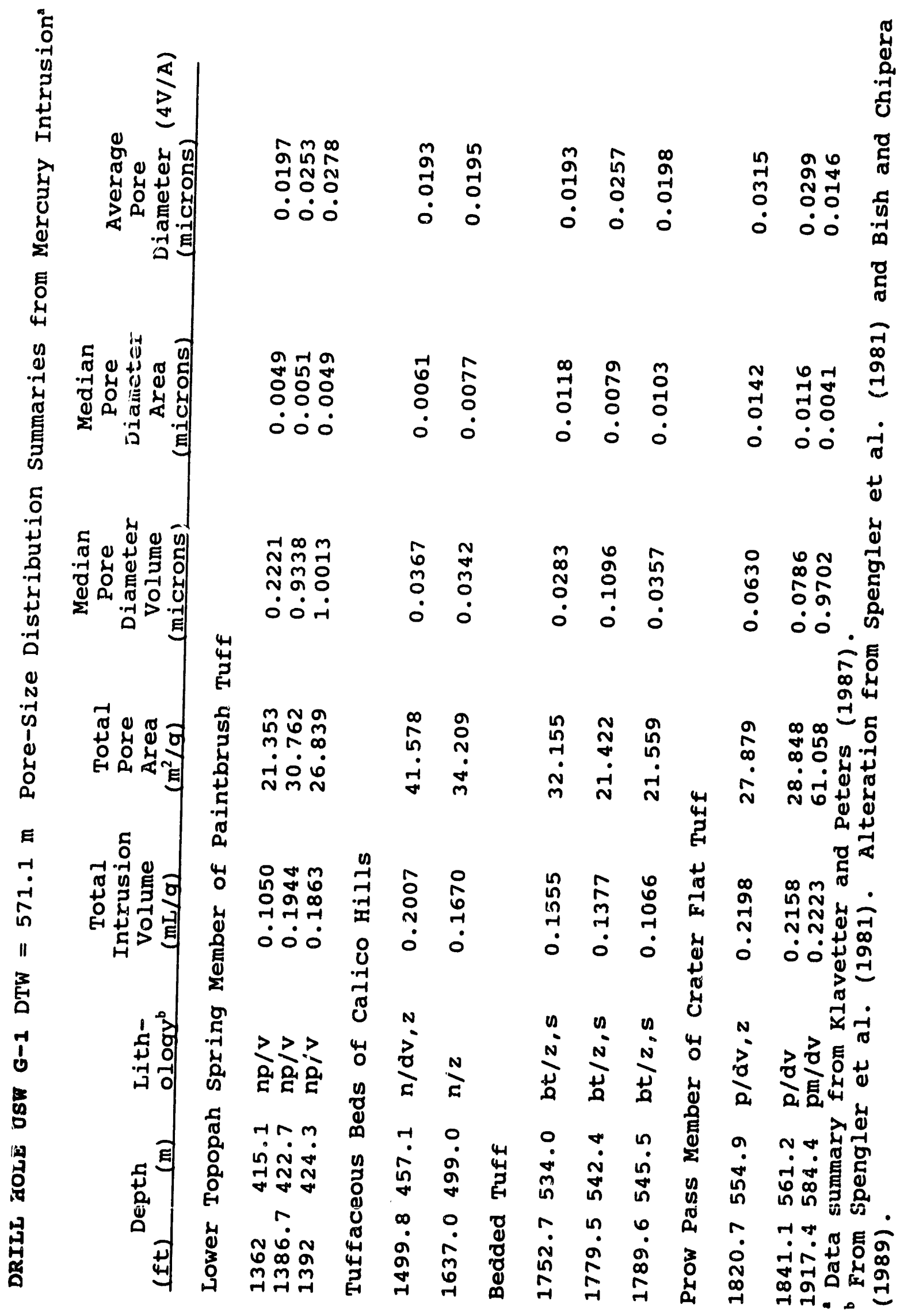




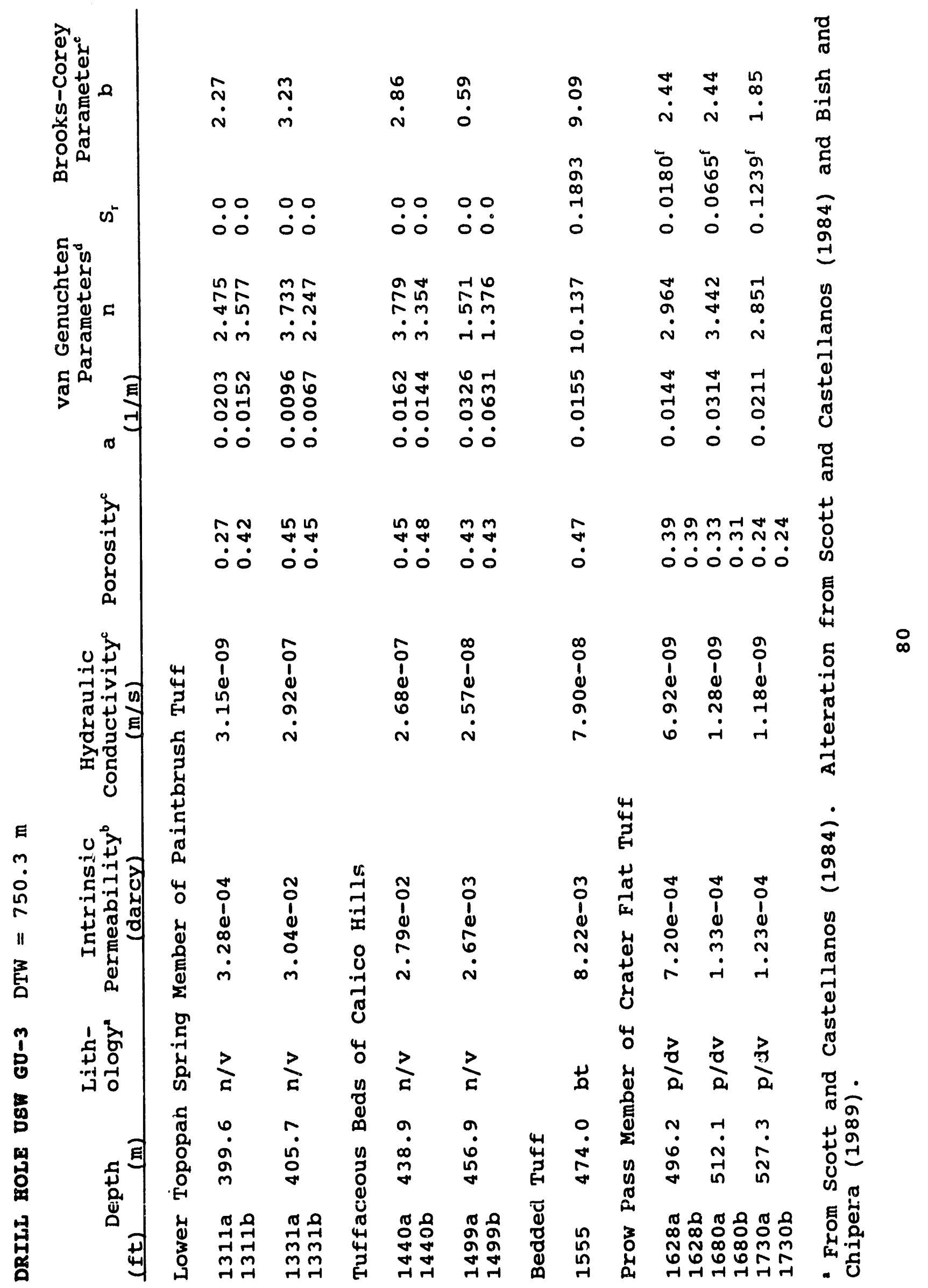




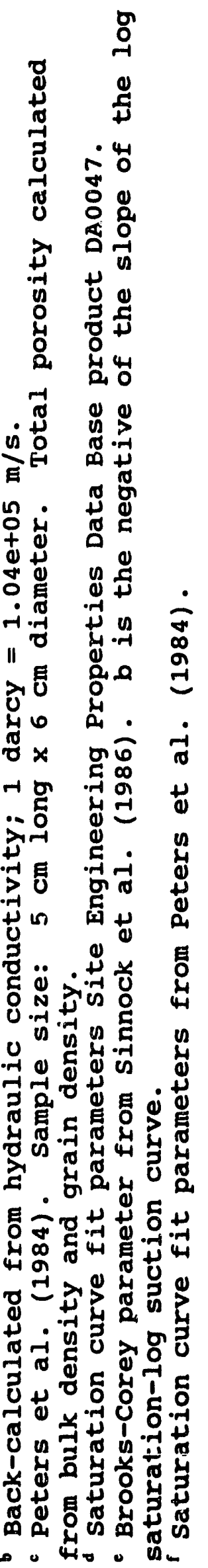




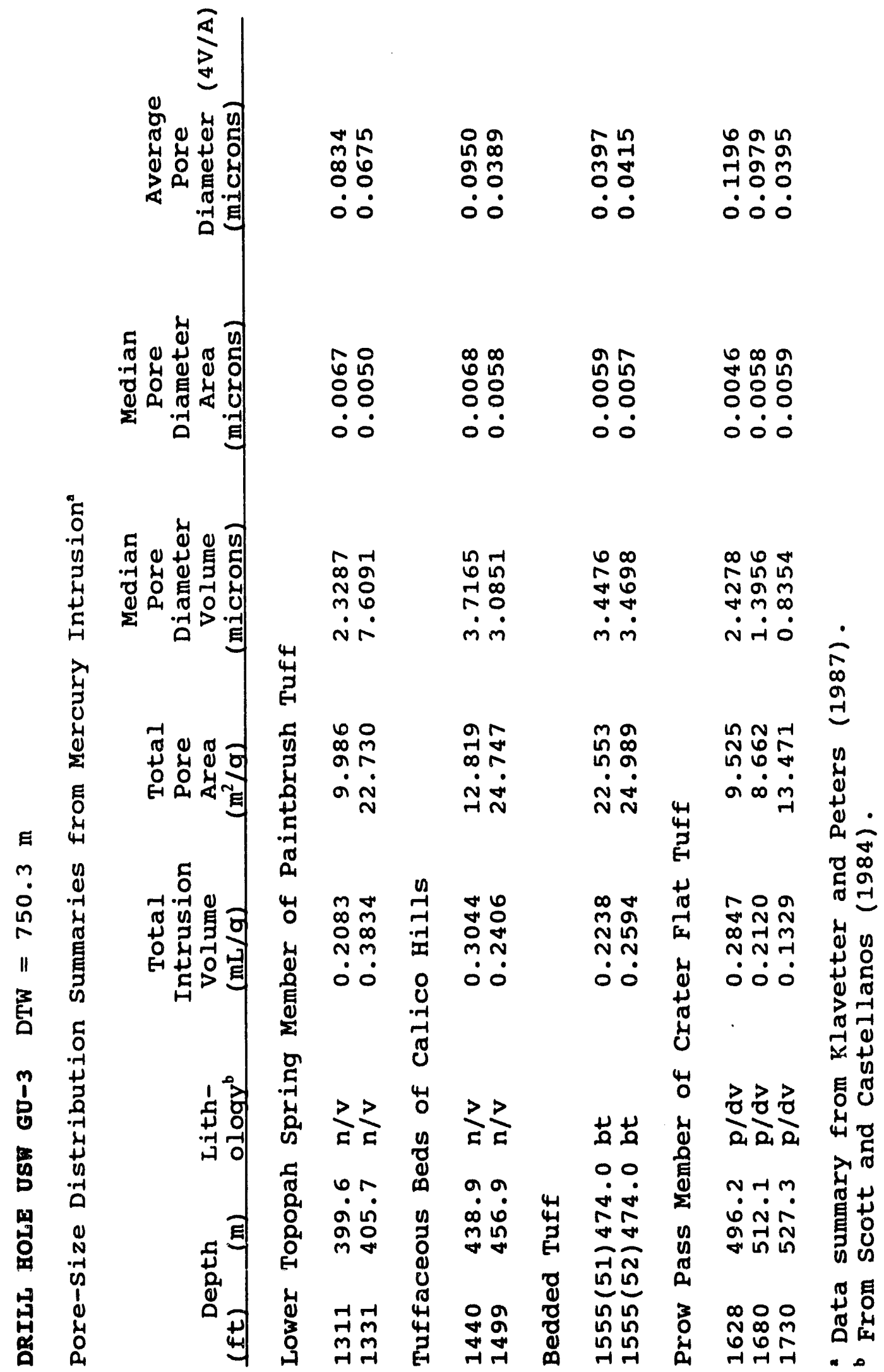




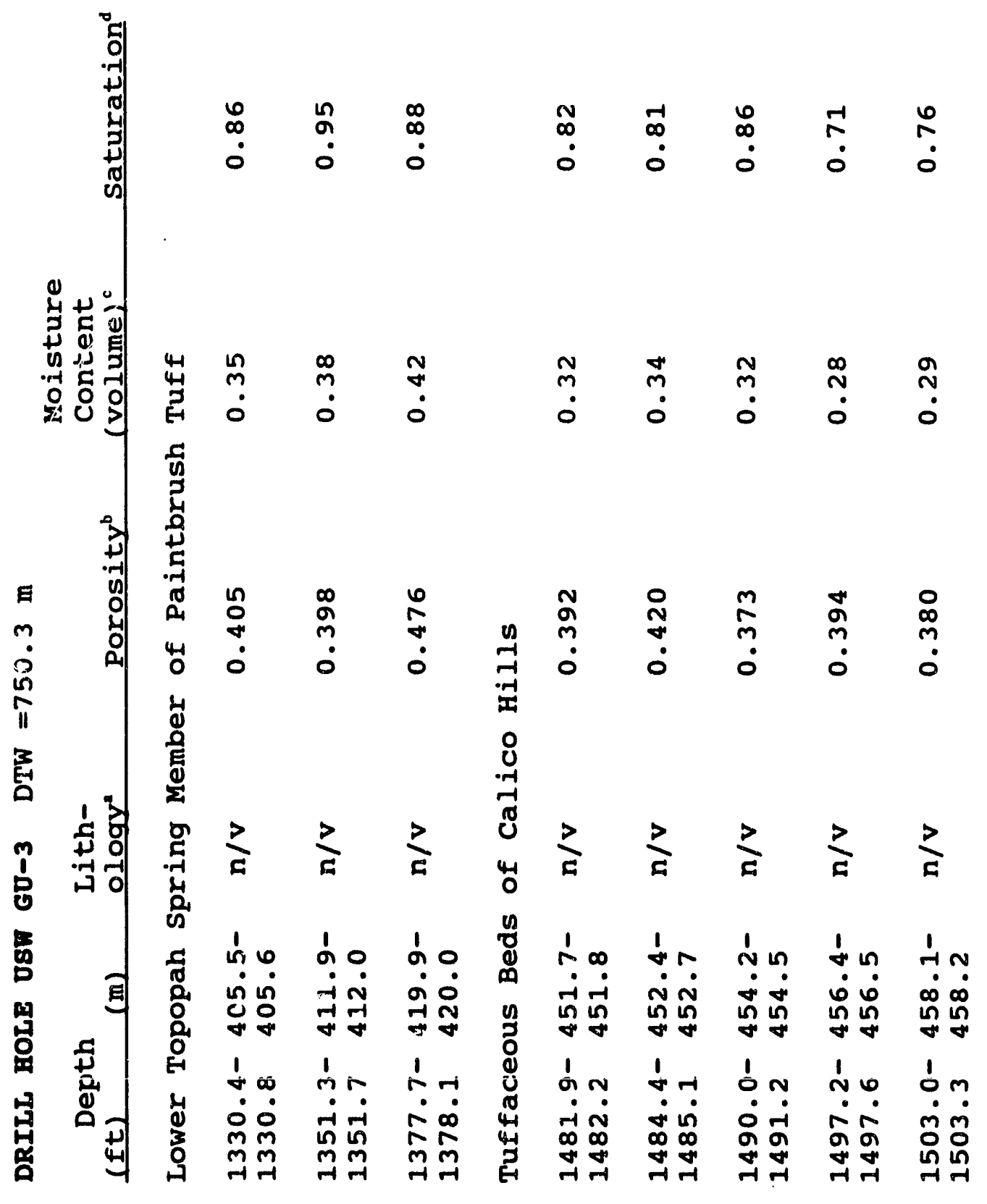




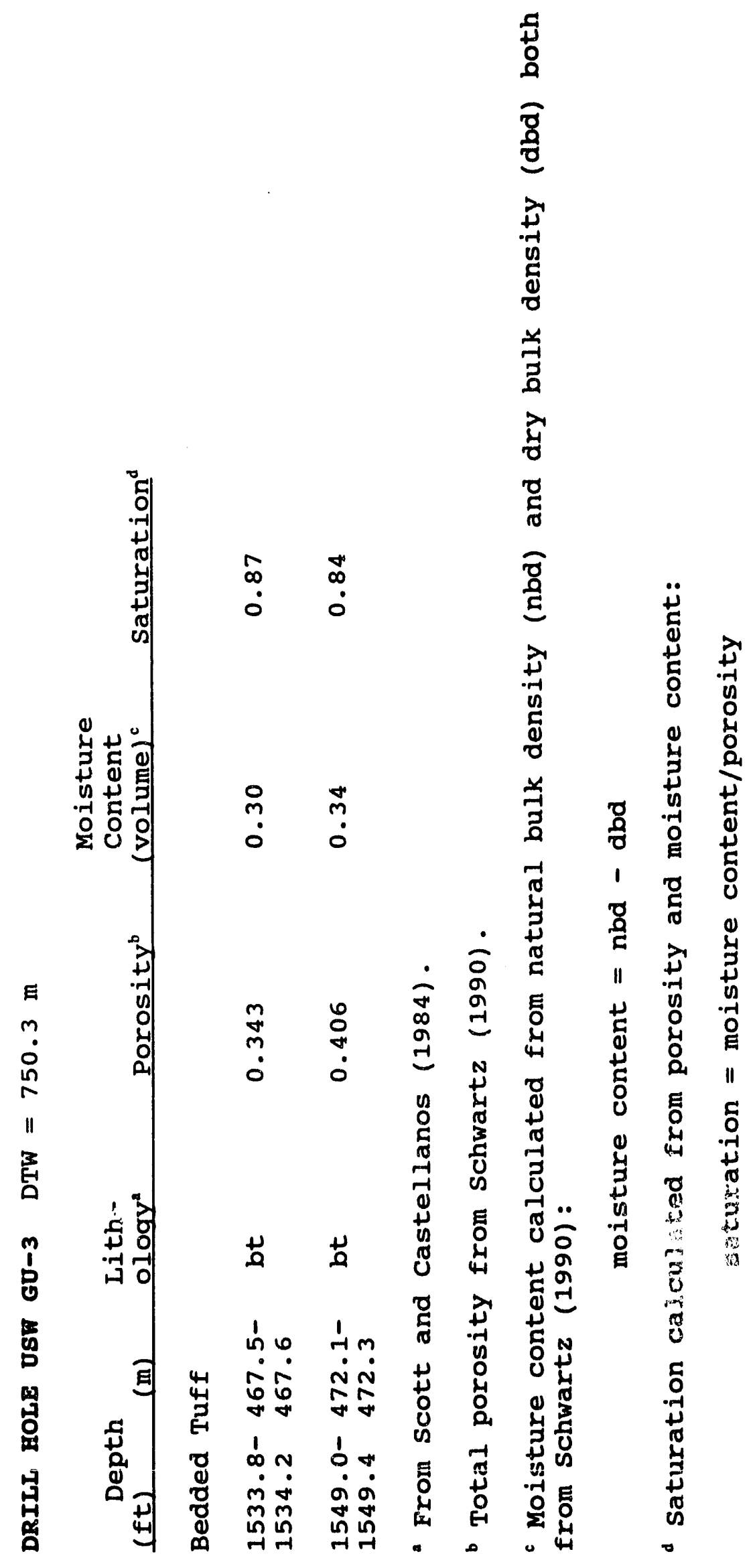




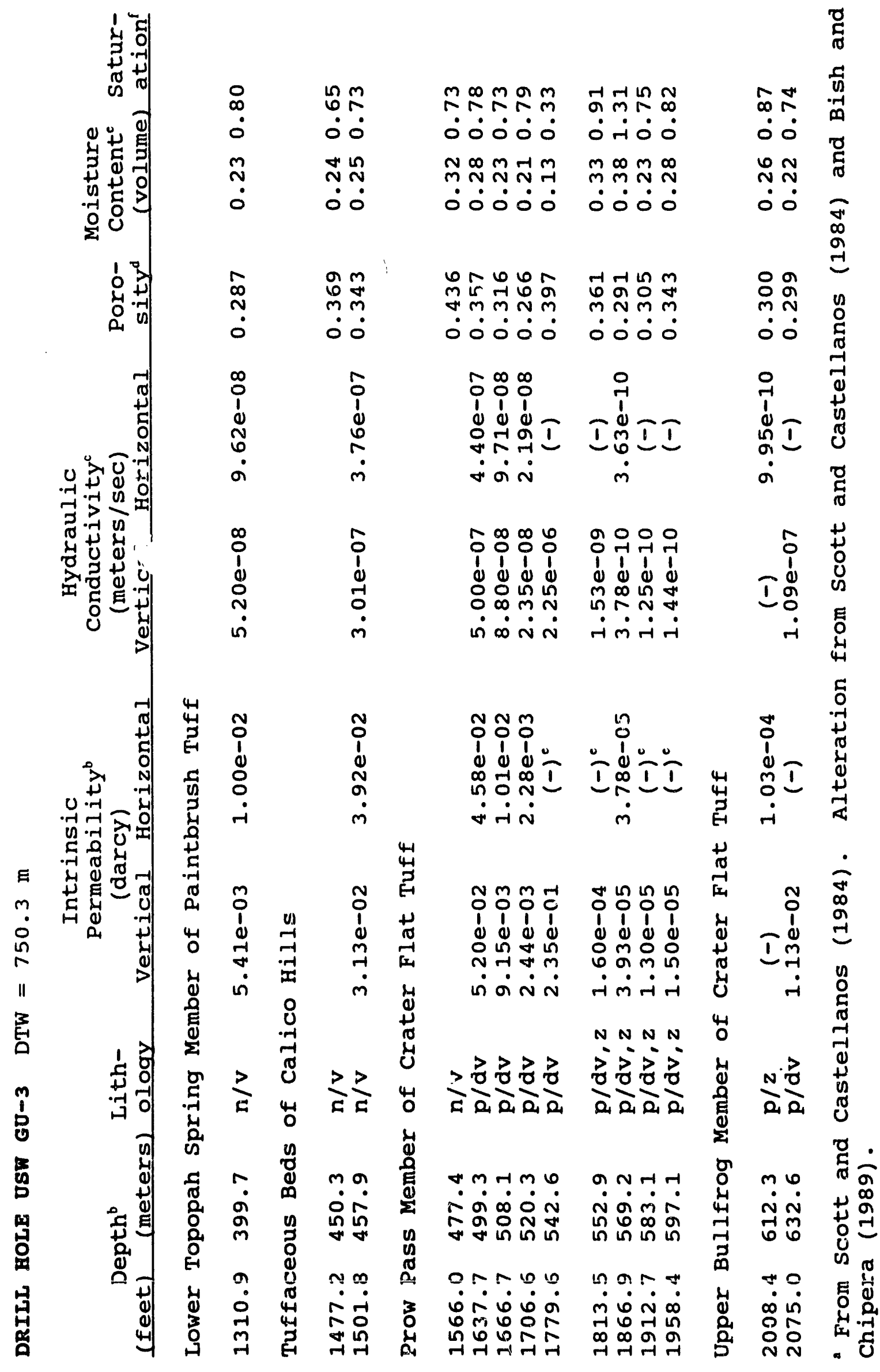




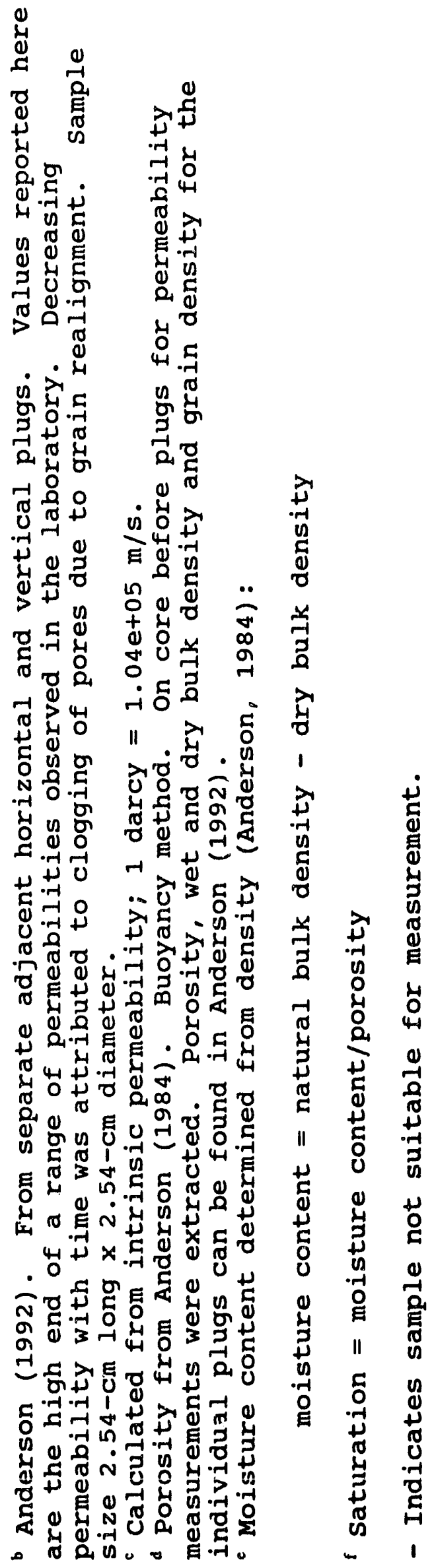




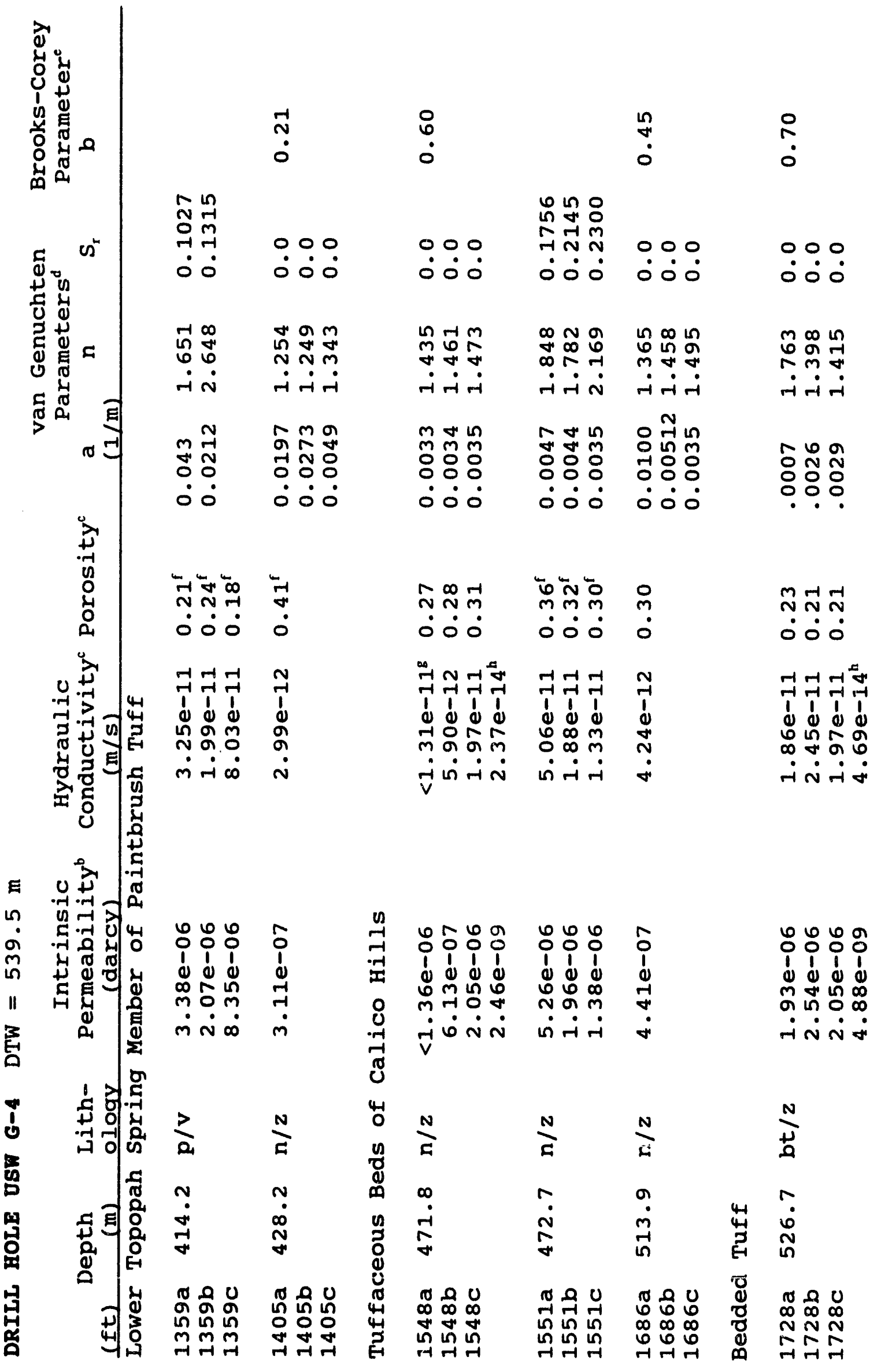




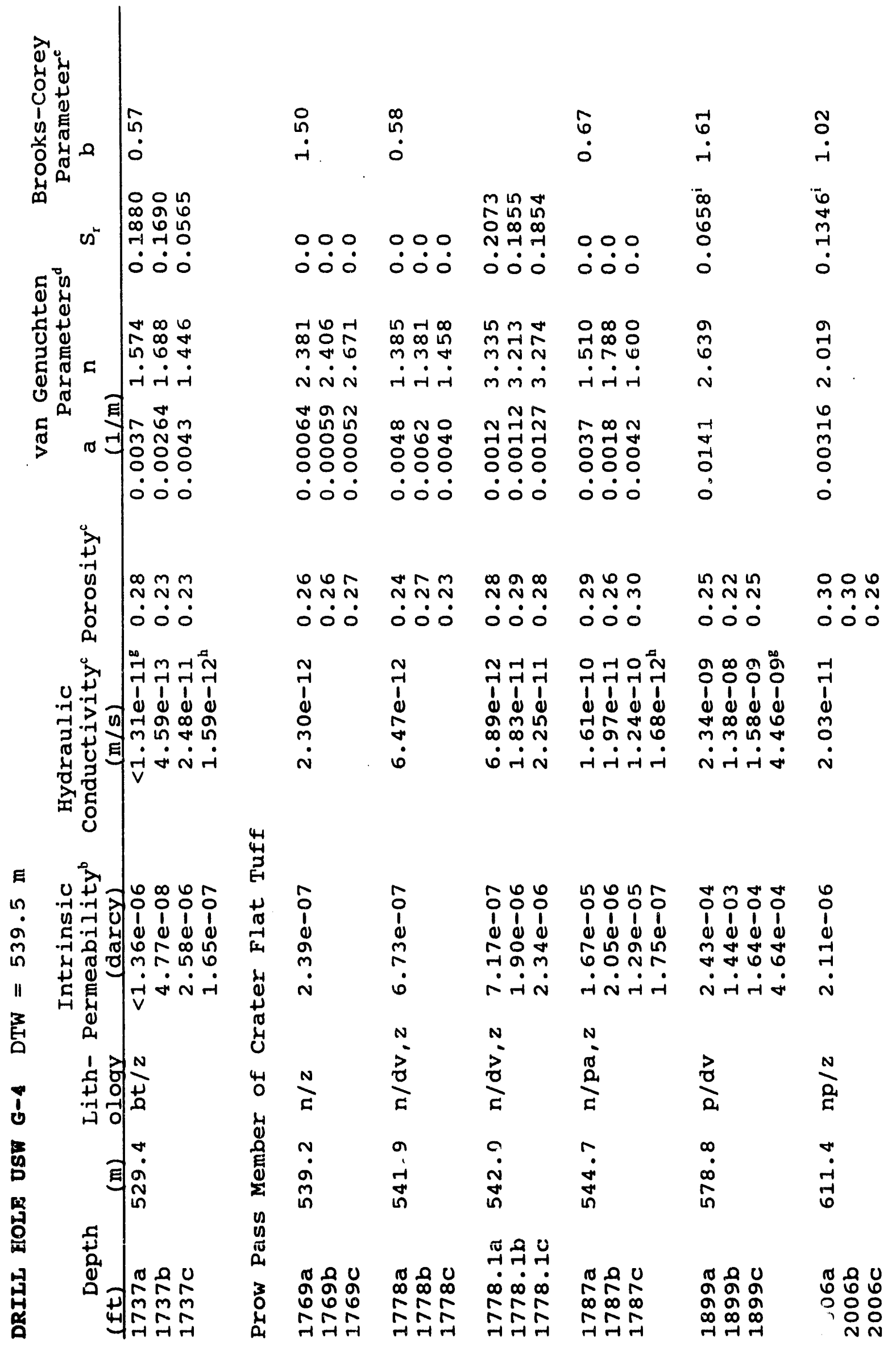




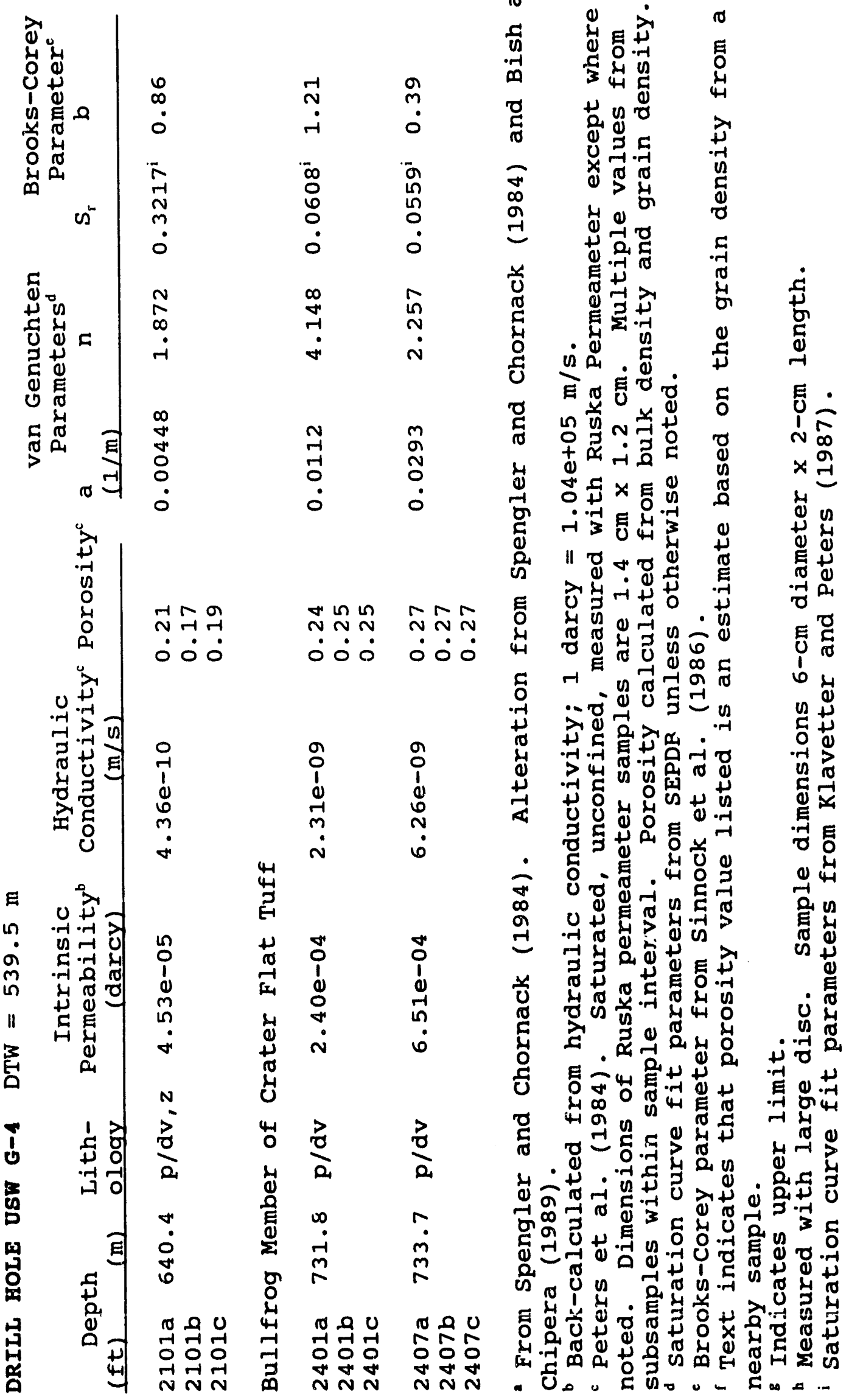




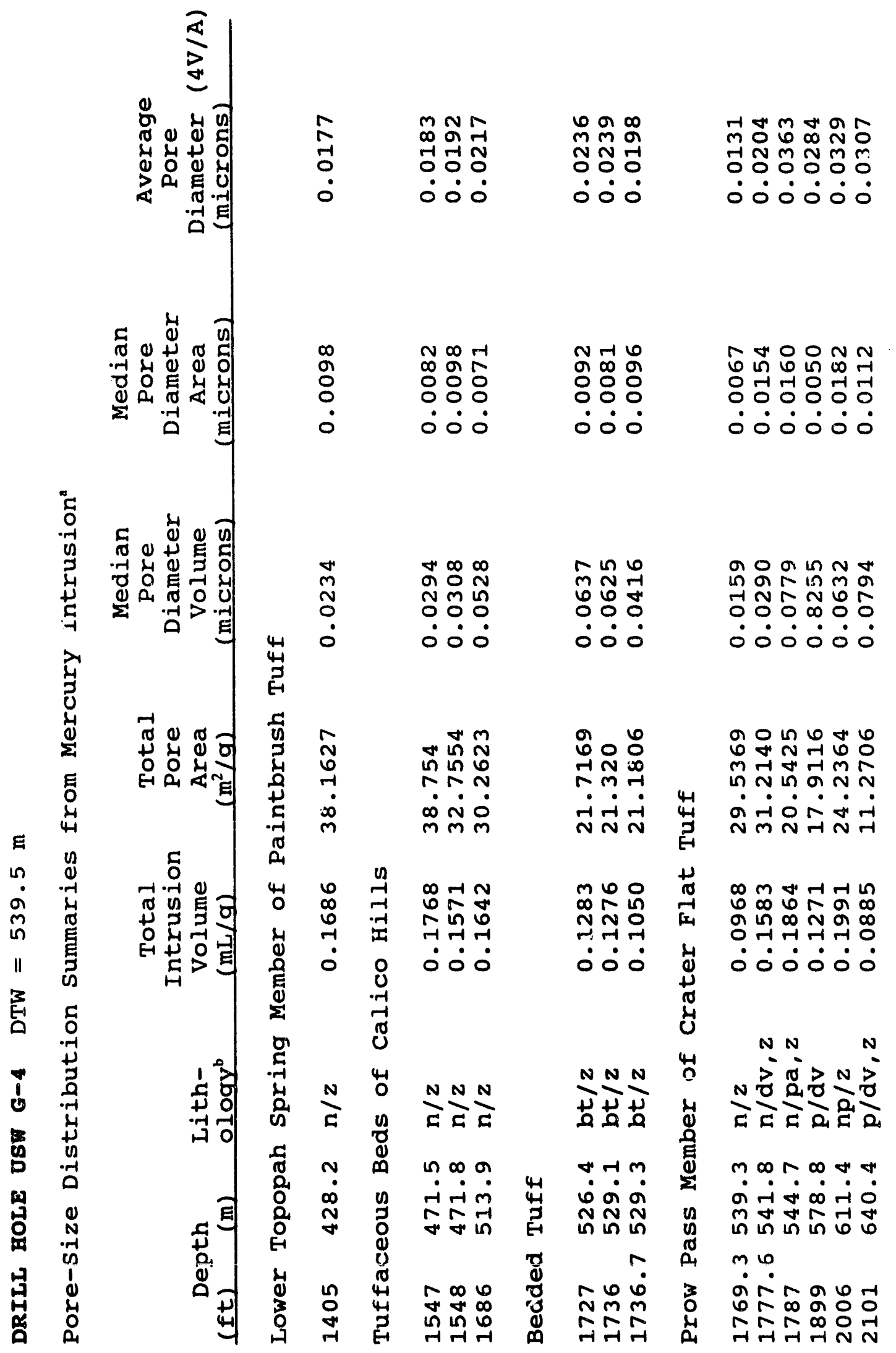




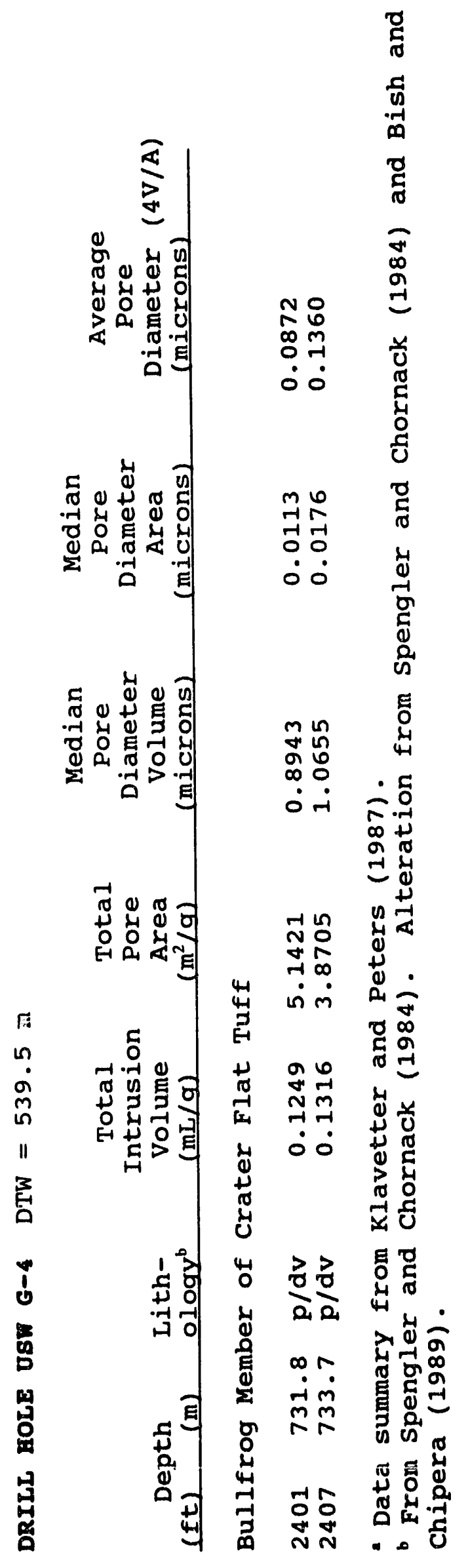




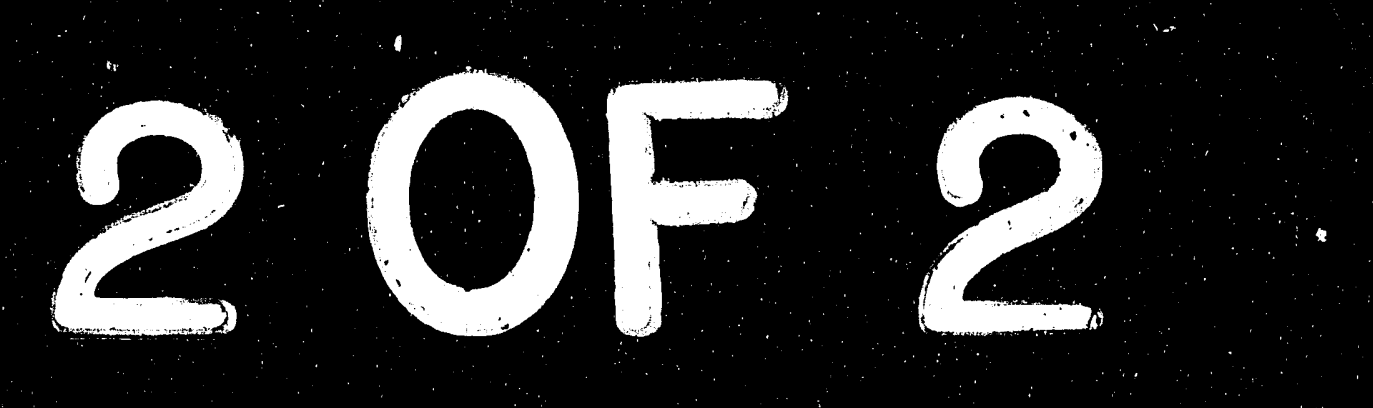

1

(i)

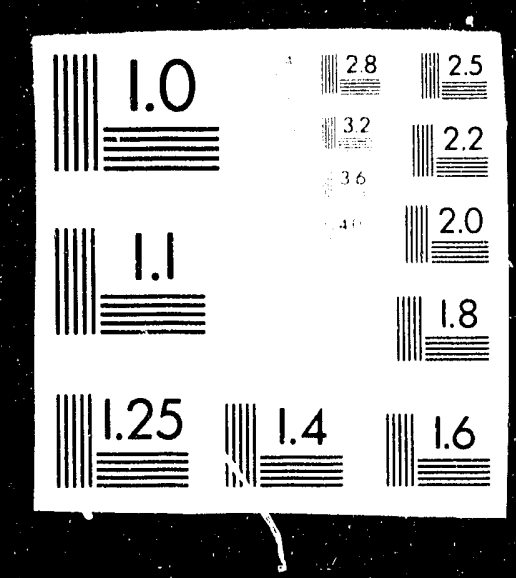

4

te 


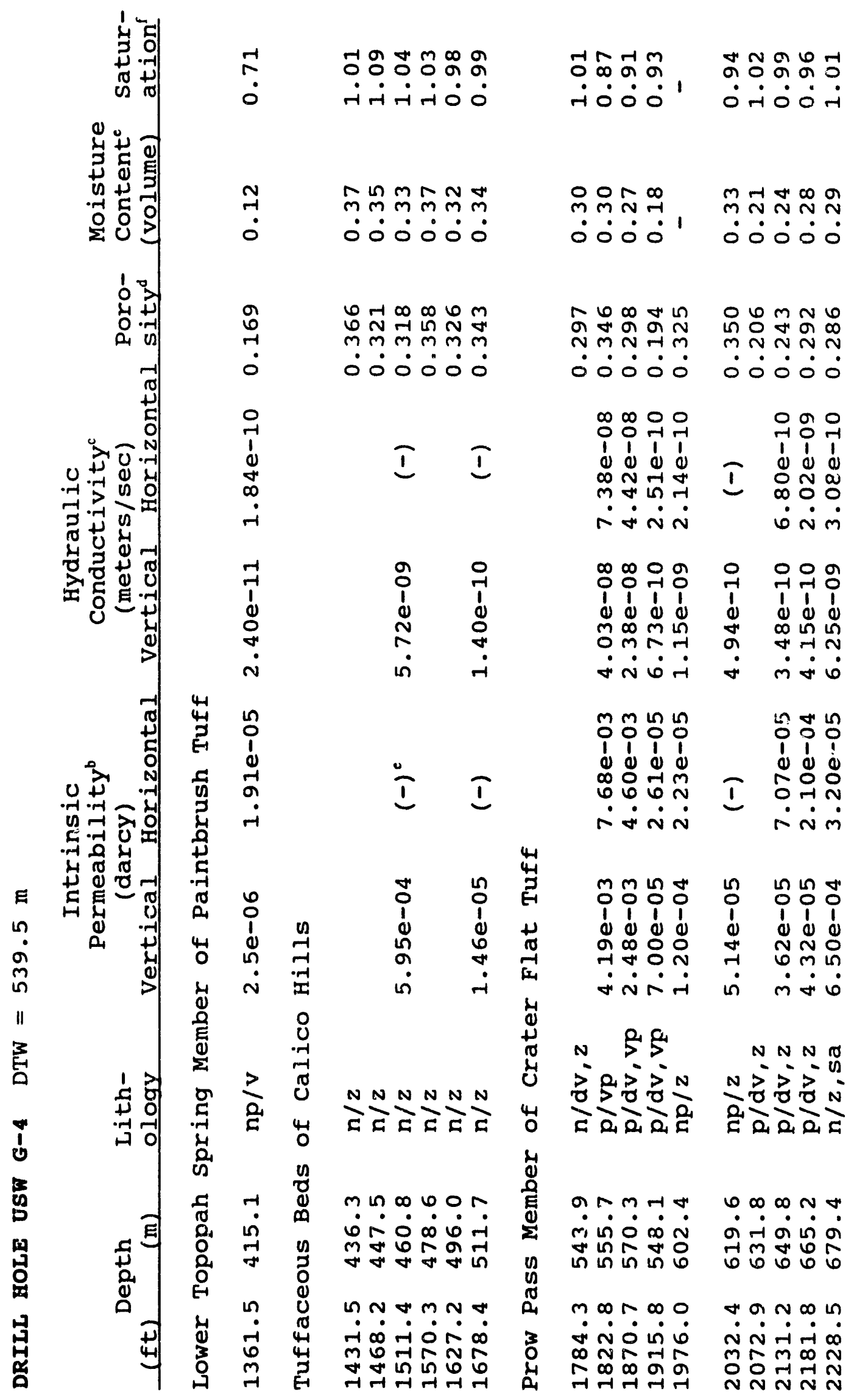




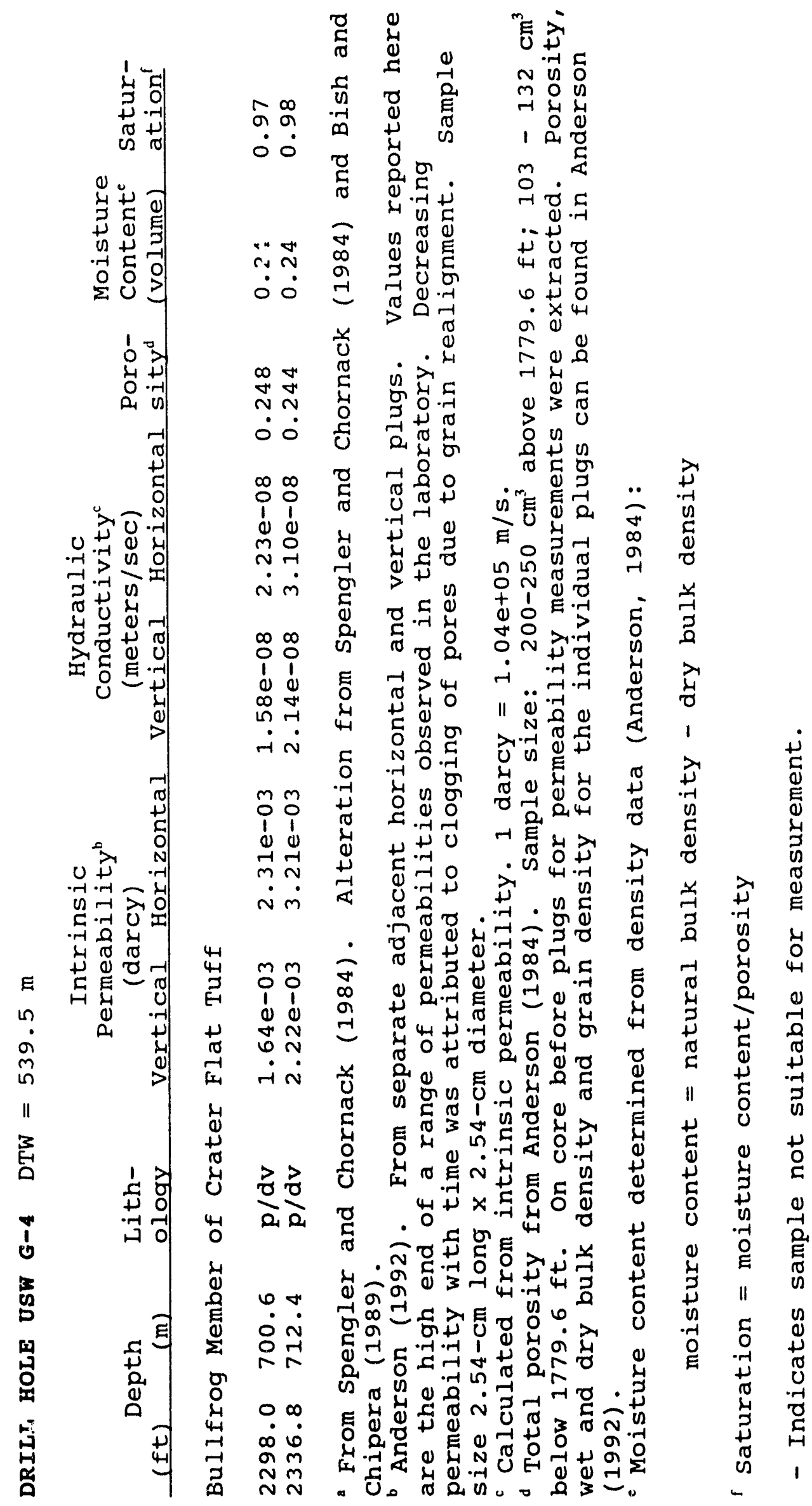




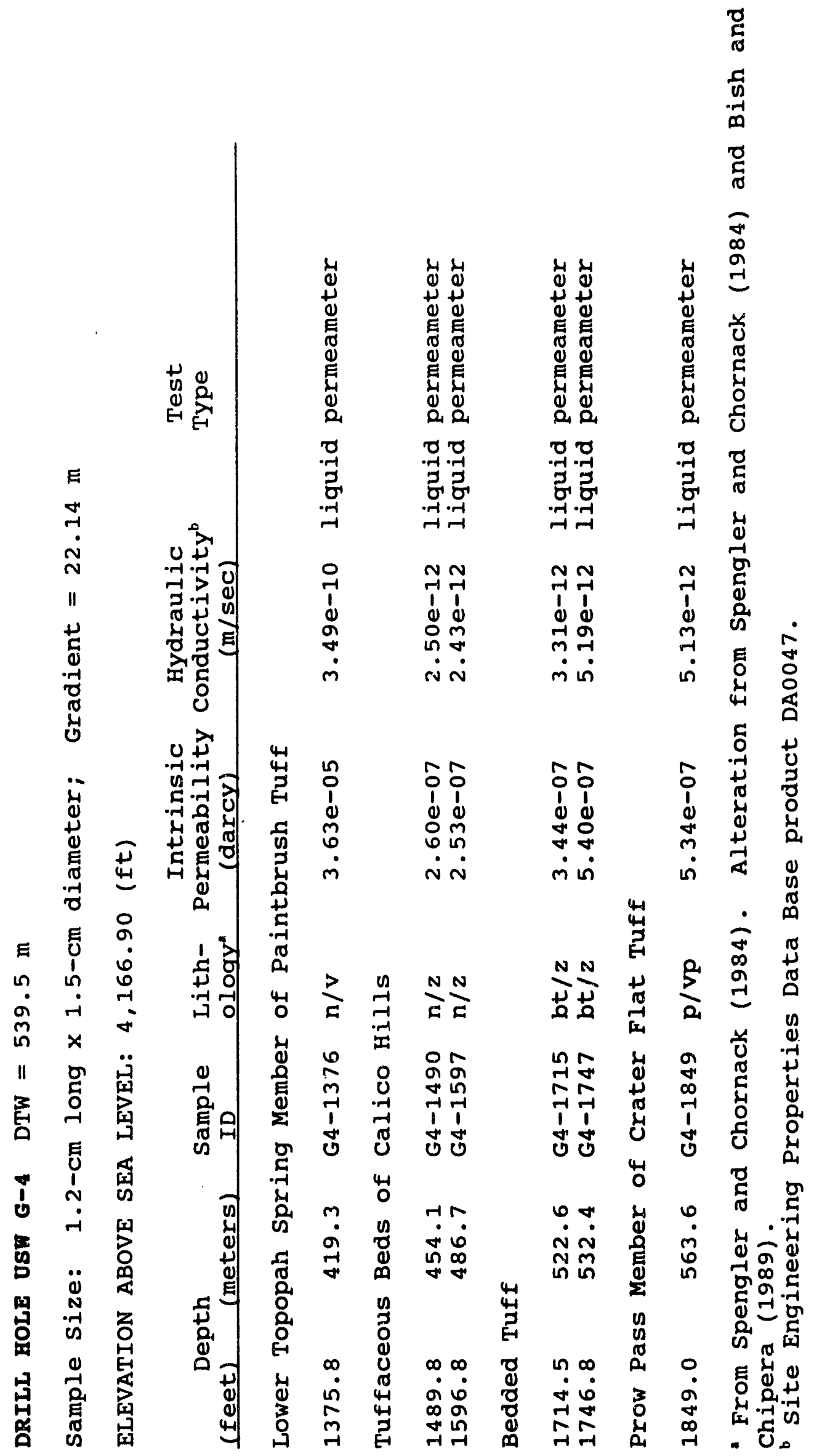




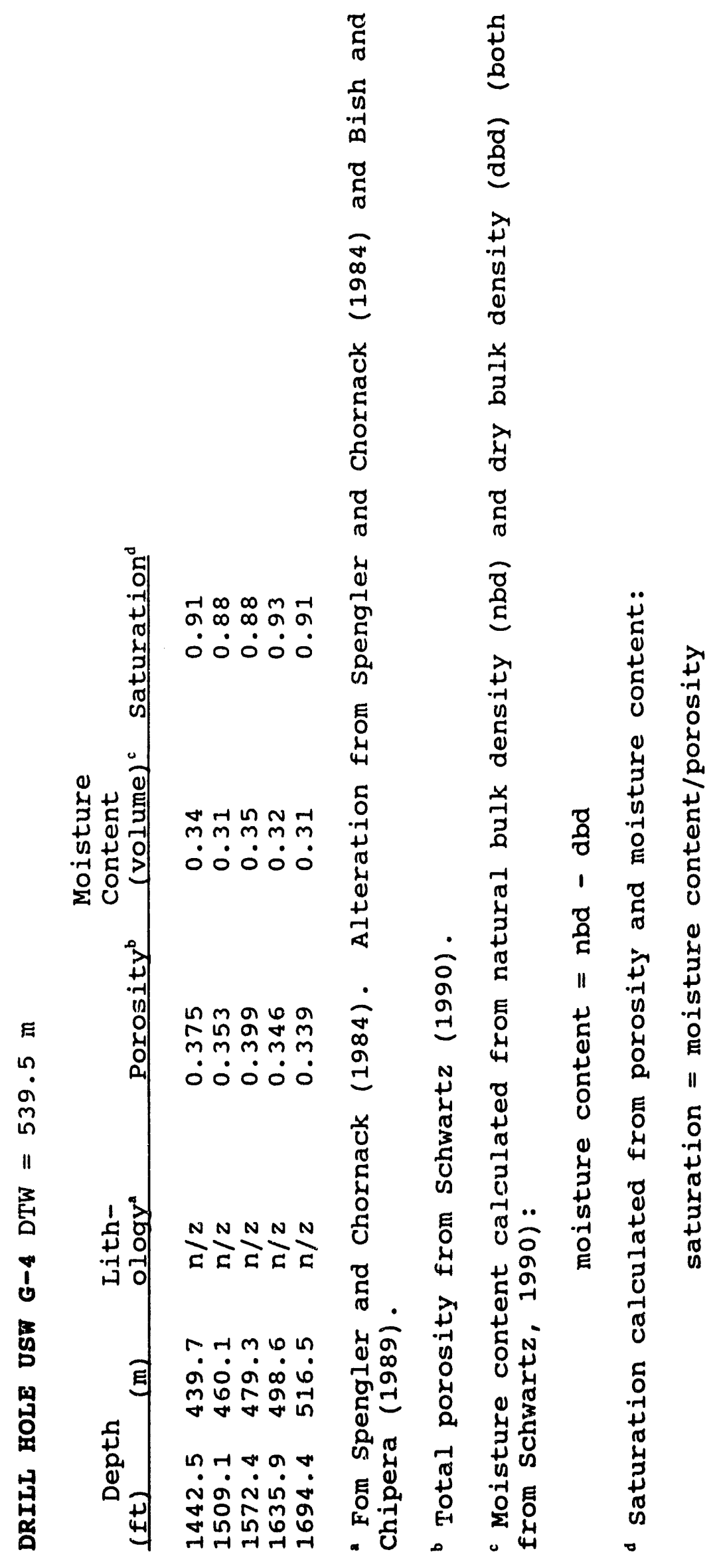


词

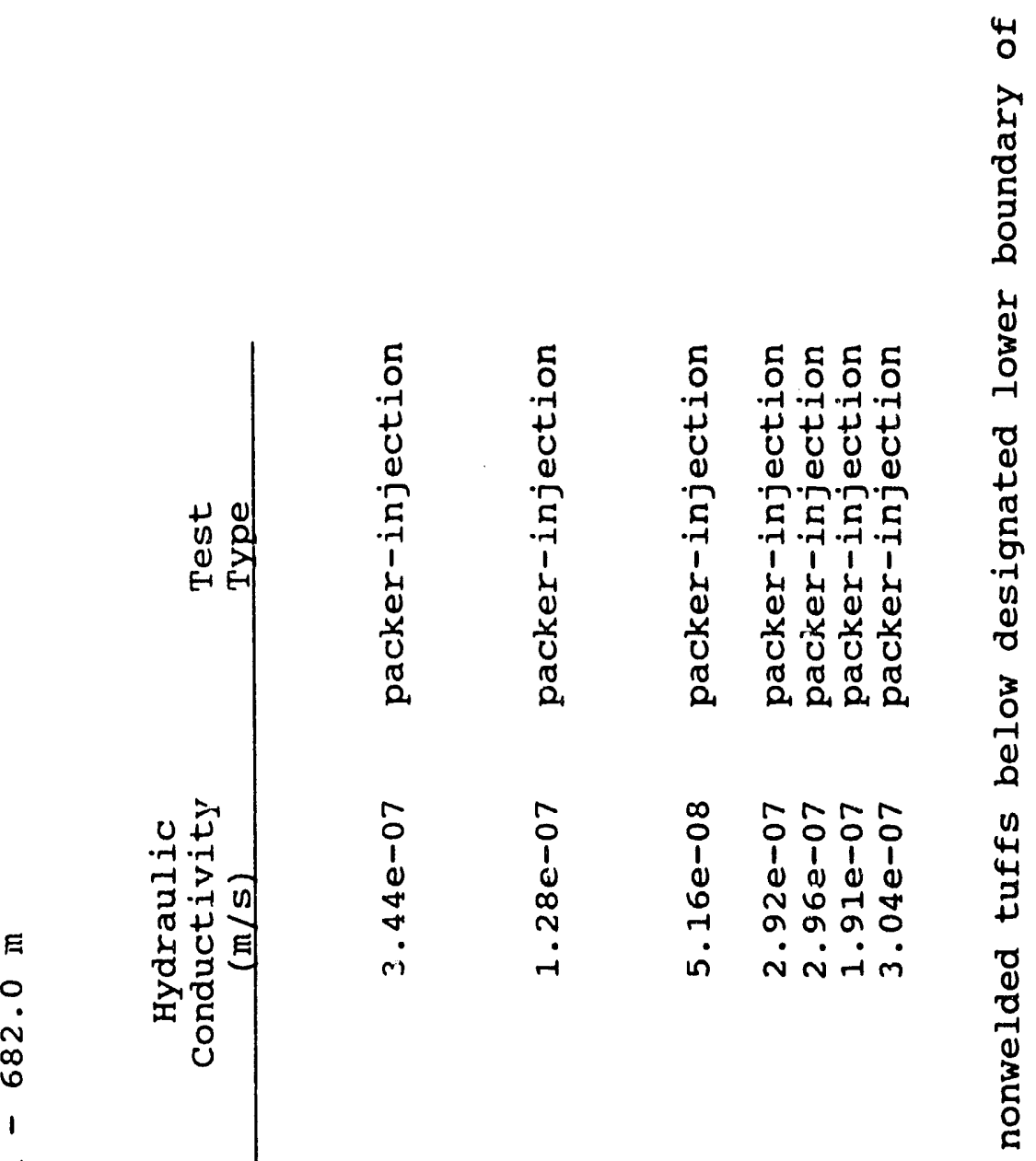

恣 苔

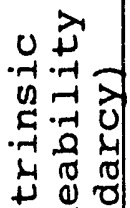

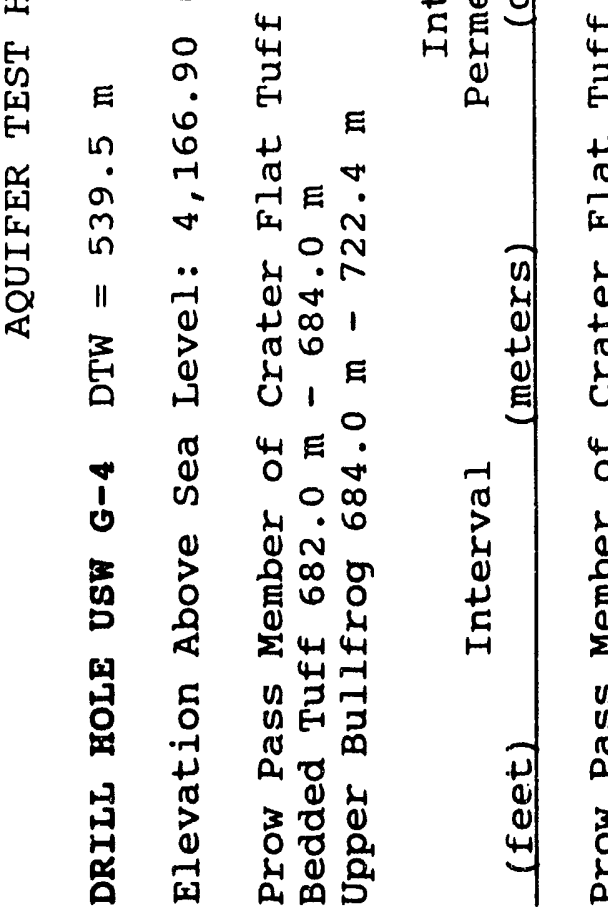

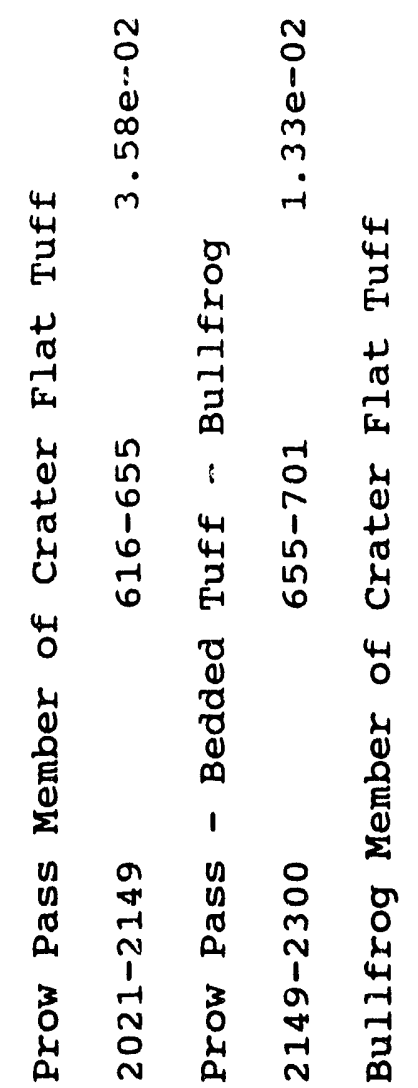

$\stackrel{m}{m}$

$+$

$\begin{array}{lllll}1 & 1 & 0 & 0 & 1 \\ 1 & 0 & 0 & 0 & 0\end{array}$

ब

m oँ कून

in $\dot{m} \dot{m} \dot{i m}$

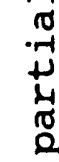

$\dot{0} \rightarrow$

잉

N $n$ n

N

i $T$ i $\infty$ \&

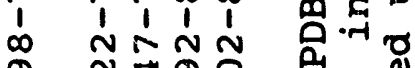

ơ N

4

ऽ नु

깅

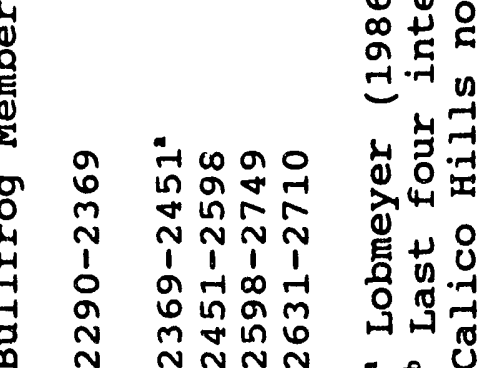

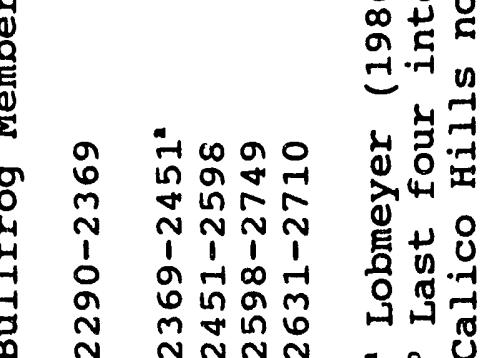

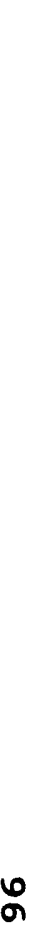




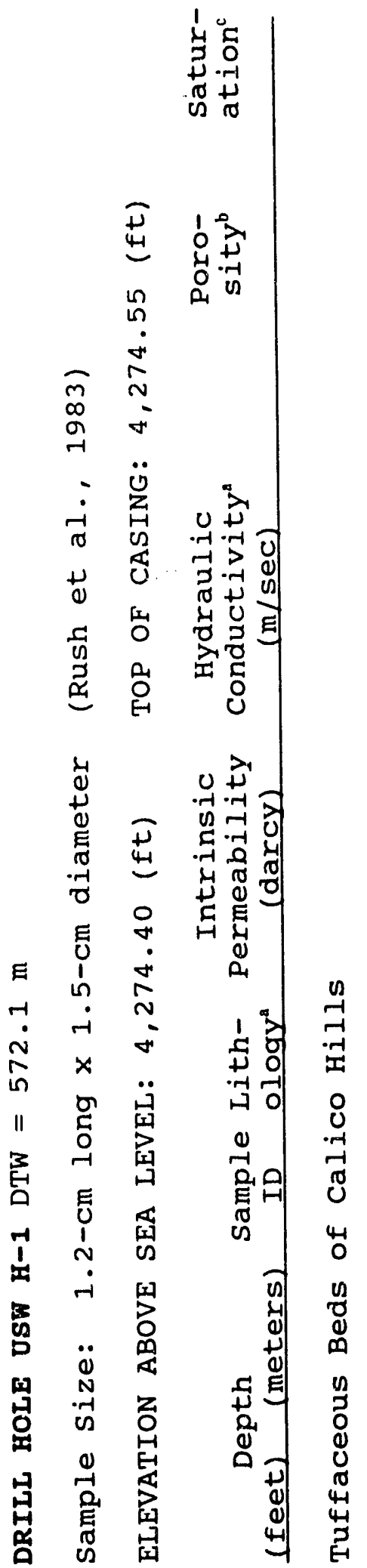

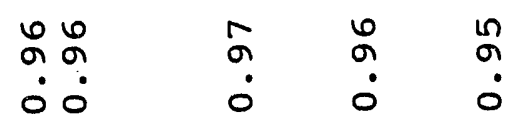

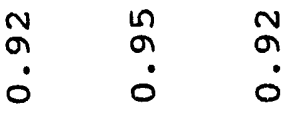

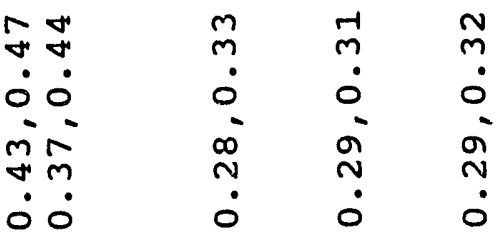

$\begin{array}{lll}m & m & m \\ \dot{m} & \dot{m} & \dot{0} \\ \stackrel{n}{n} & \stackrel{n}{m} & \dot{m} \\ \dot{0} & \dot{0} & \dot{0}\end{array}$

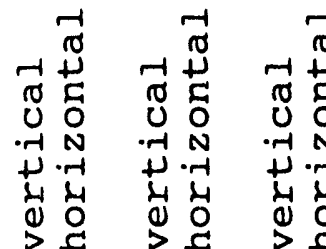

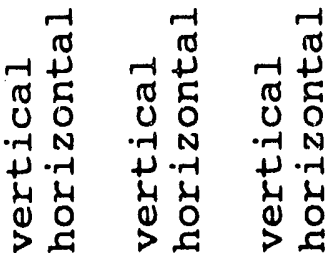

우 웅우 우의 9

$\begin{array}{rllllllll}-1 & 0 & -1 & -1 & -1 & 1 & 0 & 0 & 1 \\ 1 & 1 & 1 & 1 & 1 & 1 & 1 & 1 & 1\end{array}$

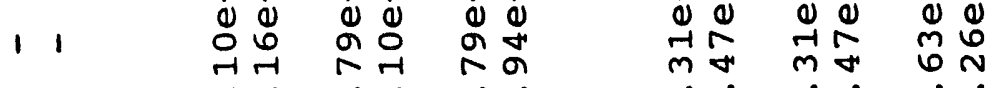

$\dot{\infty} \dot{-i} \dot{\infty} \dot{0} \quad \dot{\sim} \dot{N} \dot{m} \dot{\sigma}$

ลิ

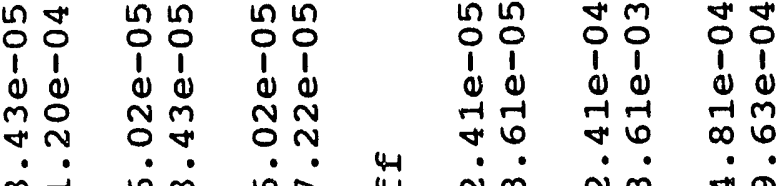

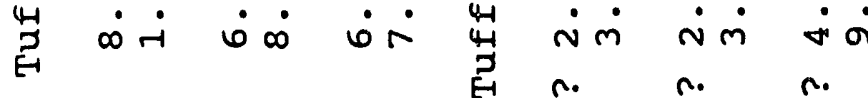

11

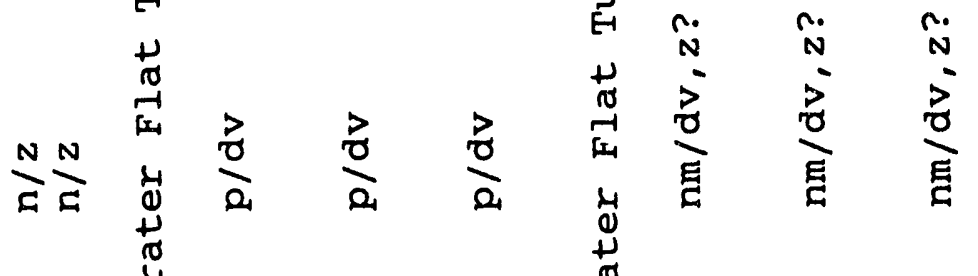

$A-1$ nen

$\stackrel{n}{m} \stackrel{m}{m}$

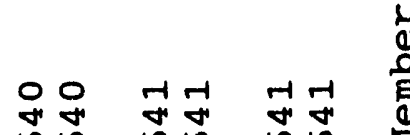

เก เก

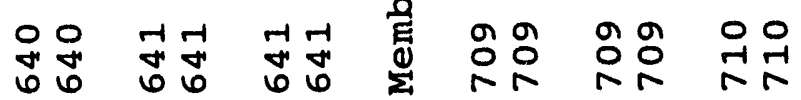

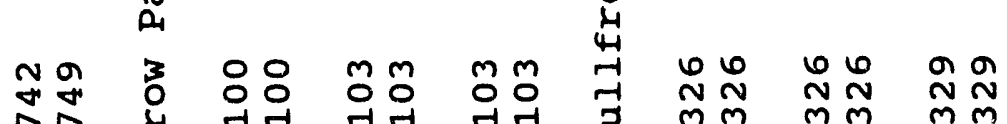
감 


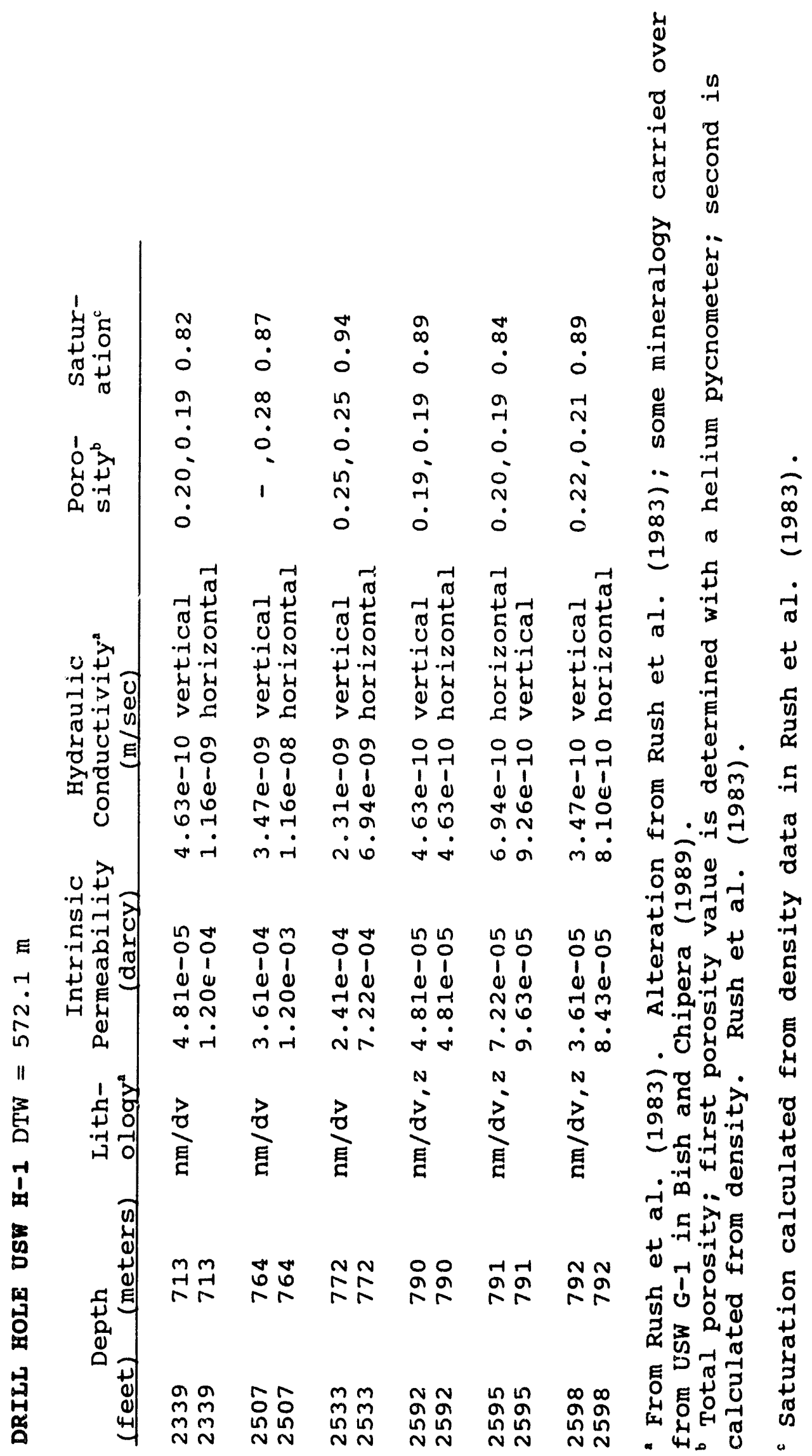




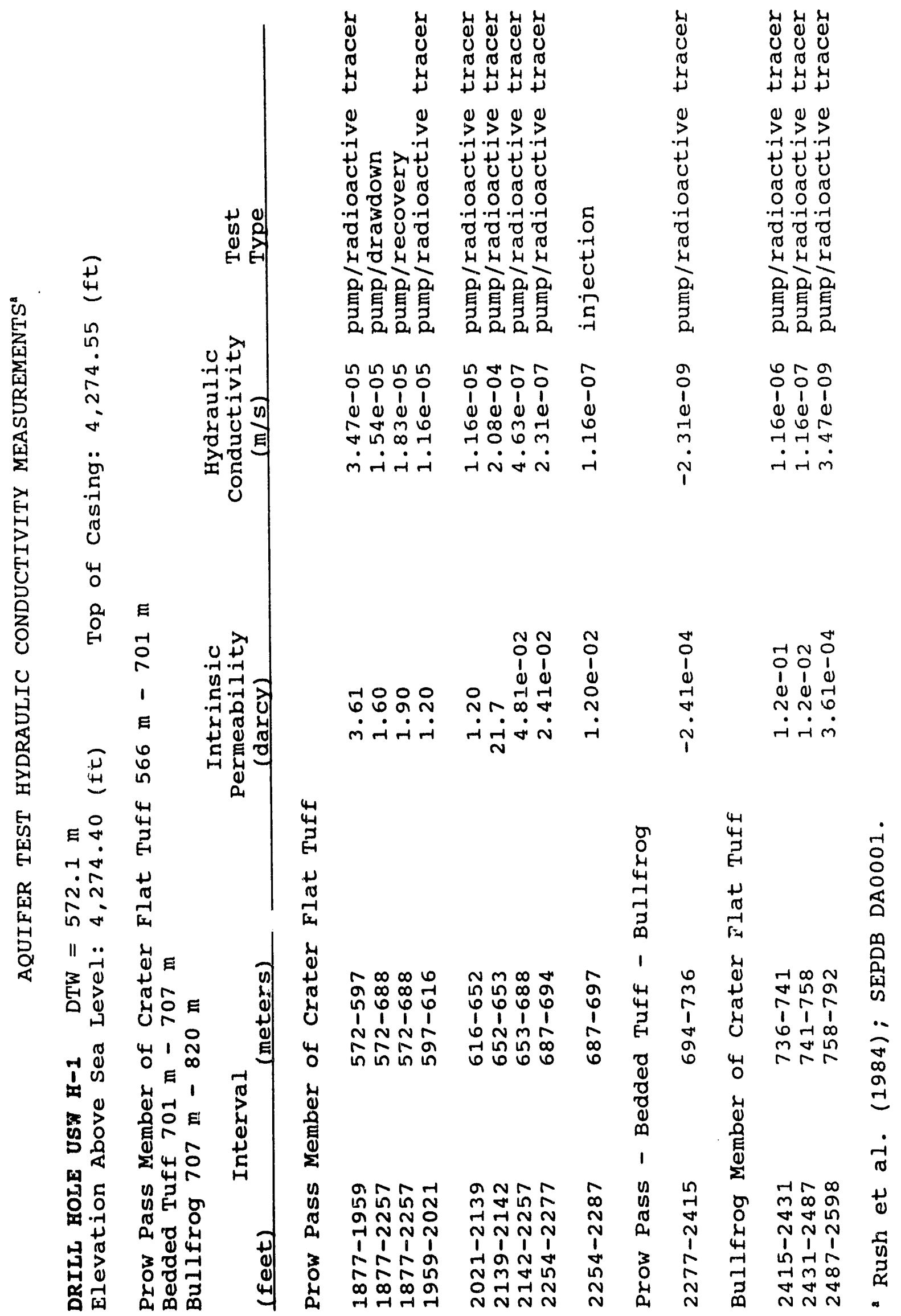




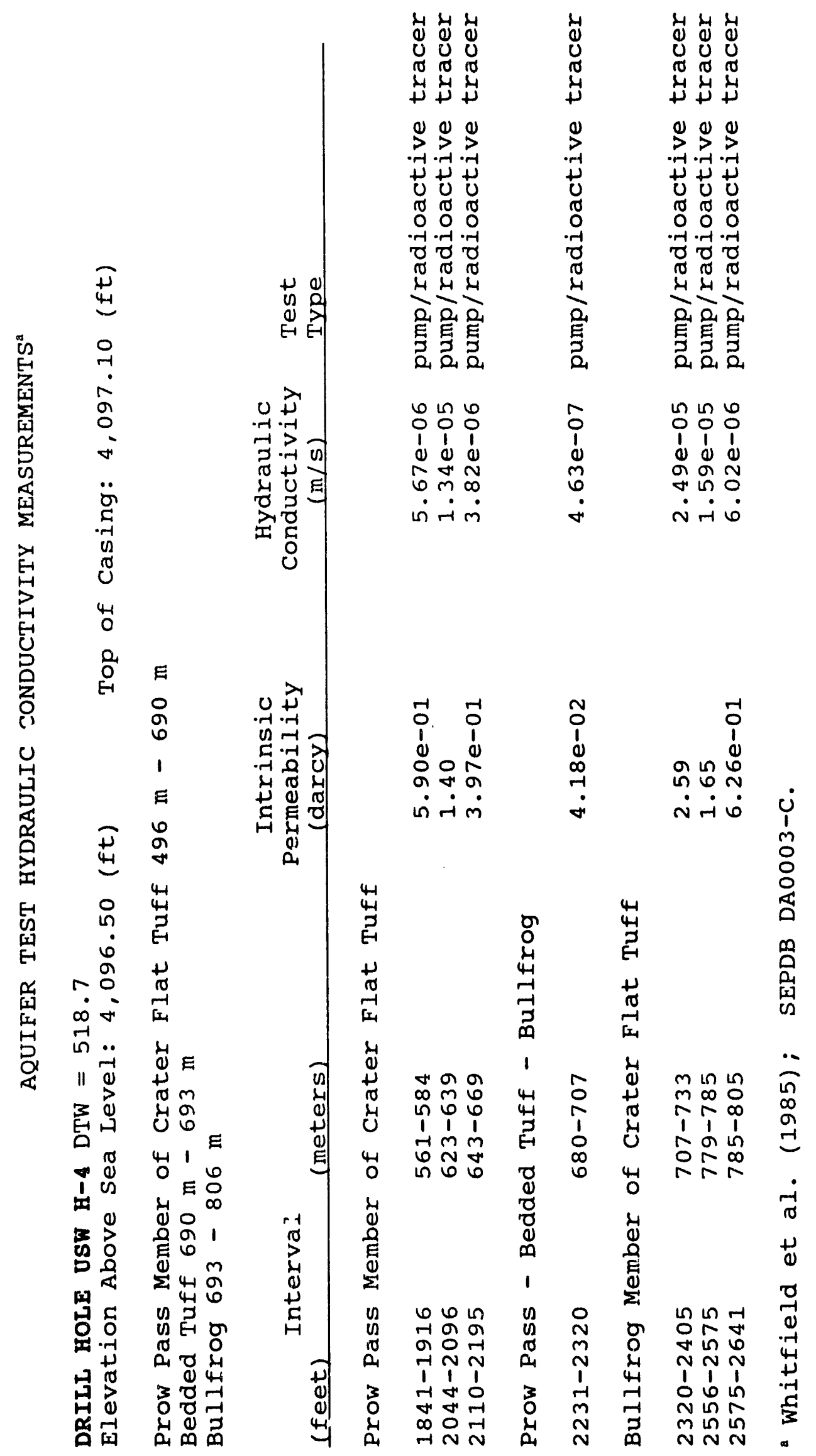




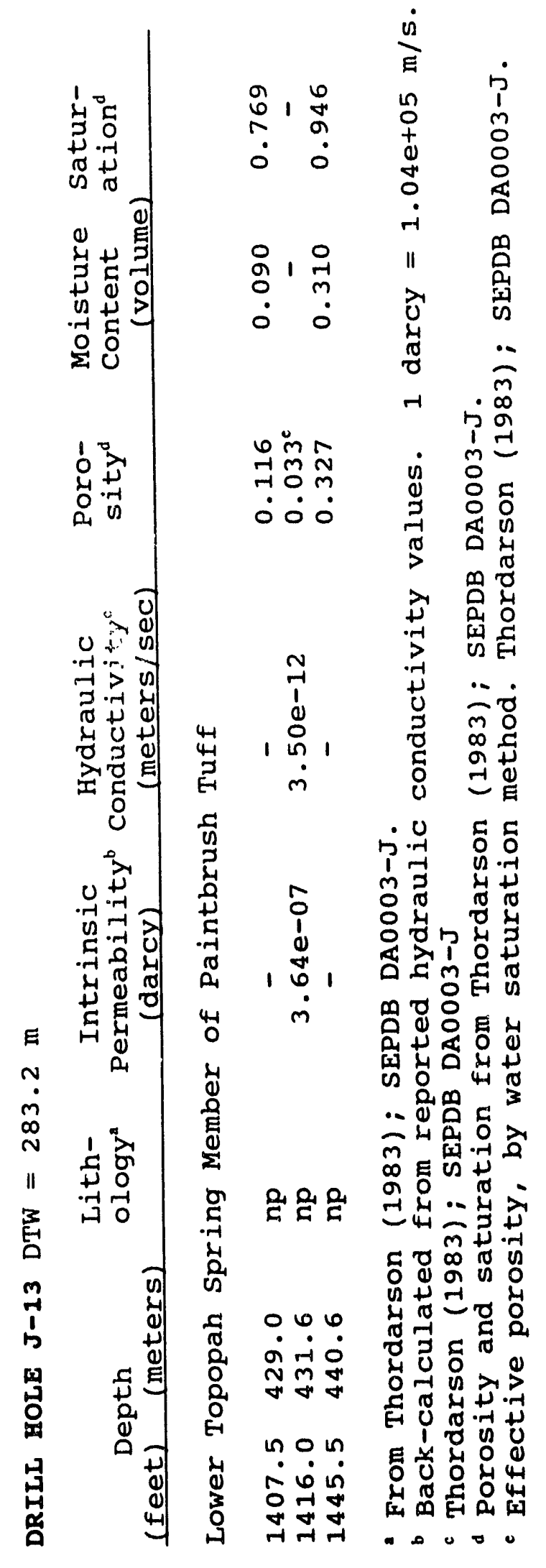




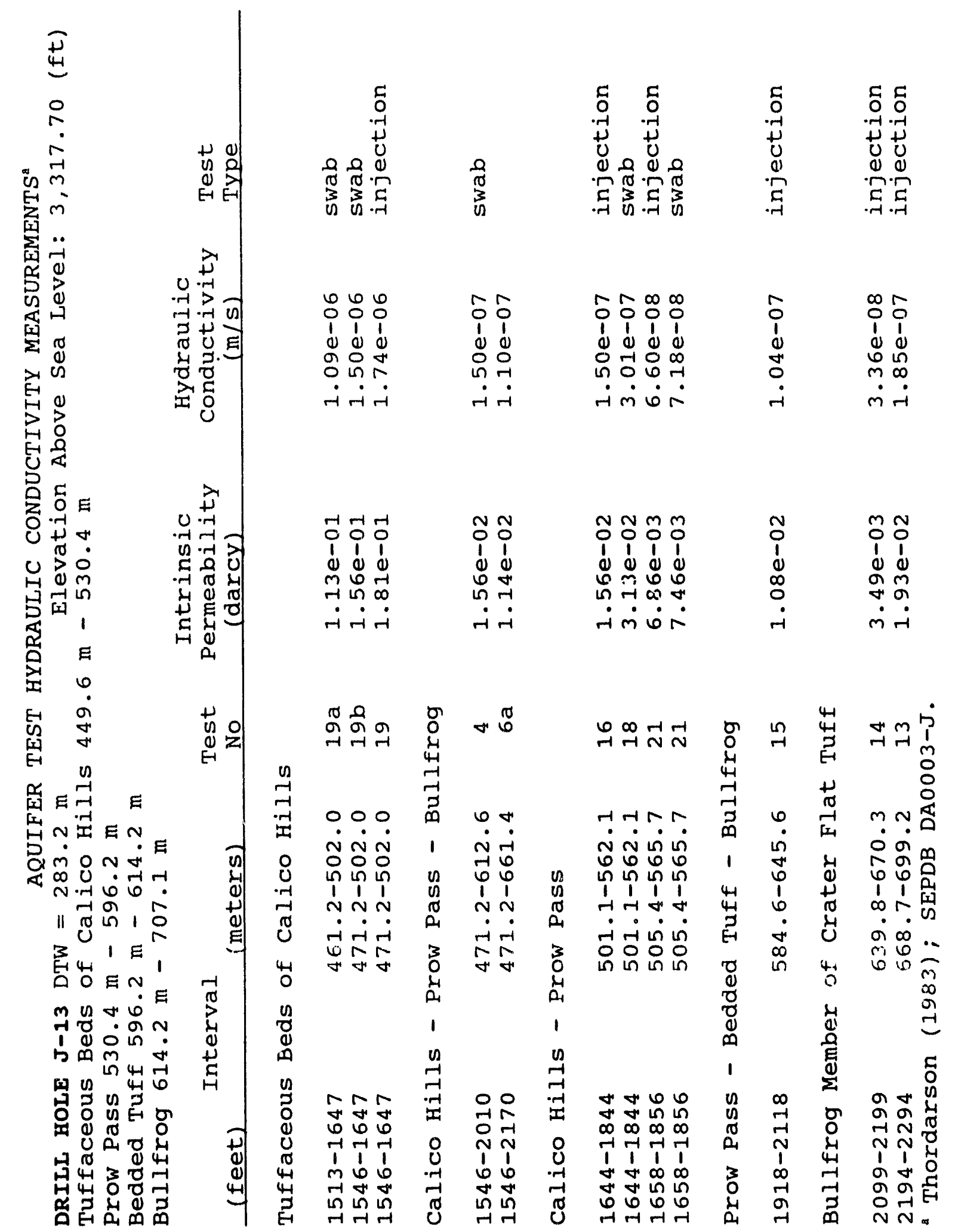



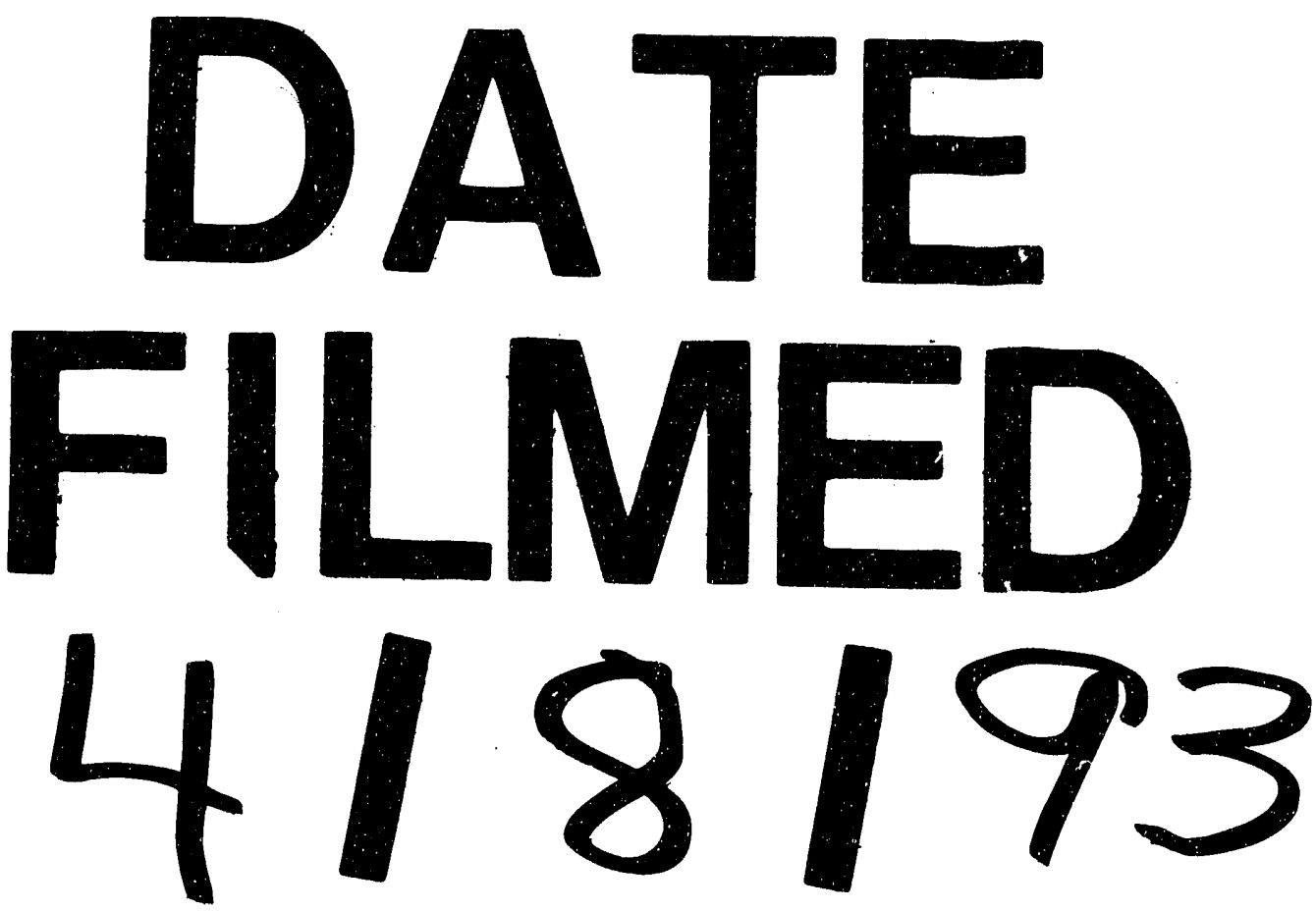